\title{
UC-NRLF
}

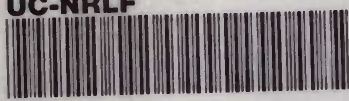

B 3319835 


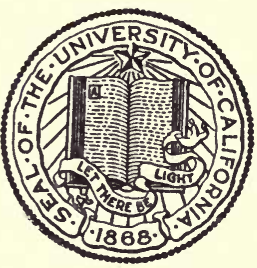

THE LIBRARY

$\mathrm{OF}$

THE UNIVERSITY

OF CALIFORNIA

Biology Library BEQUEST OF

Theodore S. Palmer 





\section{OHIO STATE \\ ACADEMY OF SCIENCE}

Special Papers No. 6

\section{The Birds of Ohio}

A REVISED CATALOGUE

BY

IYNDS JONES, M. Sc.

Published by the Academy of Science with the Emerson McMillin Research Fund

OCTOBER, 1903 



\title{
Ohio State Academy of ScIEnce
}

\author{
Special Papers No. 6
}

\section{THE BIRDS OF OHIO}

A REVISED CATALOGUE

BY

L Y NDS JONES, M. Sc.

OBERLIN COLLEGE

PUBLISHED BY THE ACADEMY OF SCIENCE WITH THE EMERSON MCMILLIN RESEARCH FUND

Publication Committee :

J. H. Schaffner, L. H. McFadden, Gerard Fowke 


\section{BIOLOGY LIBB,}

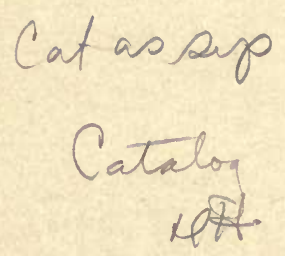

NOTE.

The study upon which this paper is based was carried on under two grants of thirty-five and seventy-five dollars each from the Emerson McMillin Research Fund, and the expense of publication is met by the further aid of the same fund.

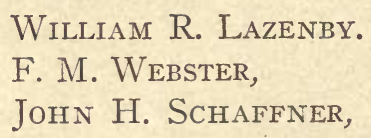

Trustees. 


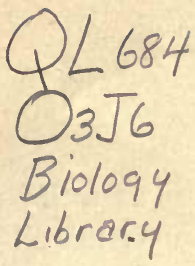

\section{PREFACE.}

Dr. J. M. Wheaton transmitted his monumental "Report on the Birds of Ohio" to Prof. J. S. Newberry, Chief Geologist of Ohio, on November 1, 18\%9. It was finally printed by the state and distributed in 1882. One year later, at the first Congress of American Ornithologists' Union, held in New York, September 26-29, 1883, a committee was appointed to whom was referred the question of revising the classification and nomenclature of the Birds of North America. That committee's work was completed, accepted, and the results printed in a Check-List* early in 1886. Until the publication of this Check-List there had been no uniformity in the nomenclature of birds; each author practically building his own system. Dr. Wheaton adopted, in a somewhat modified form, "The nomenclature ..... of Dr. (Elliot E.) Coues in his Check-List of North American Birds," published in 1874. That system followed the customs of the time by beginning with the highest and ending with the lowest forms. The nomenclature adopted by the committee of the American Ornithologists' Union* turned the old system about, beginning with the lowest and ending with the highest forms, as they were then regarded. Seven years after the completion of his work and four years after its publication, therefore, the nomenclature of Dr. Wheaton became obsolete, for the new nomenclature found immediate acceptance the country over, and has since been the working basis of all American Ornithologists.

The need of a Revised Catalogue of the Birds of Ohio has been sorely felt, chiefly that the nomenclature might be uniform with that of all more recent publications on Ornithology. The score of years which have elapsed since Dr. Wheaton's Catalogue was issued have seen other changes

*The A. O. U. Check-List of North American Birds, for sale by L. S. Foster, 30 Pine street, New York City. 
as well as those of nomenclature, making the call for a revision all the more imperative. The changes in the physical features incident to the fuller settlement of the state have been attended by changes in the whole fauna, the bird population changing with the rest.

Keenly feeling the need for a state catalogue of our birds which should embody the latest results of field work and conform to the adopted system of nomenclature, the writer appealed to the Ohio State Academy of Science, at its meeting in December, 1900, and found ready sympathy in the plan for a revision. A liberal portion of the McMillin fund was placed at his disposal for the purpose of prosecuting the work, and it is largely that substantial help which makes it possible to present the finished report at this early date. With this fund it was possible to mail upward of two hundred lists of birds of probable occurrence to different parts of the state for reports from local bird students, and to visit several little known regions of the state for the purpose of studying the bird fauna there at first hand. A list of those who kindly contributed notes and who gave other assistance will be found elsewhere.

The nomenclature adopted in this Catalogue conforms to that of the American Ornithologists' Union Check-List, Second Edition and Supplements succeeding. While this system is not free from faults, and while another revision seems imminent, it is not within the province of this catalogue to anticipate much of such revision. Some questions relating to the validity of species and subspecies which occur in Ohio await settlement. In these few cases I have been obliged to use my best judgment respecting the questions at issue. If that judgment proves unsound I trust that the reader will consider the limitations of time and material under which I am obliged to complete this work. 
patient search. Additions to this list would be gladly received.

\section{Relative Abundance.}

In speaking of the relative abundance in Ohio of the several species of this catalaogue I have made use of the more than threescore reports contributed by bird students scattered over most of the state. None of these reports give evidence of any more system in determining the relative abundance than Dr. Wheaton's and his colaborers' work shows, hence the comparisons drawn will seem fair. It is to be hoped that some system for the determination of the relative abundance of birds may soon be brought forward; until that is done we cannot hope for accurate results in this field of knowledge. Dr. Wheaton's observations and those of the persons on whom he relied for information covered only a small fraction of the state, to be sure, but the regions covered may be assumed to have been representative of most of the state at least. It will appear in the discussion of this interesting subject that the author has often quoted himself without the mention of others. Where that is the case the reports received from observers have been too conflicting to be of use, and he has been driven from the unknown to the known. The necessary differences prevailing among bird students as regards the time spent in study, the time of day when the observations are made and the topography covered, furnish no means of comparison unless these elements are known. Field work done at noon only will fail to discover such birds as are quiet during that time. Field work which does not cover certain regions will result in omitting such species as resort only to such regions. Unfamiliarity with notes and songs will often result in the failure to discover certain secretive species, or will fail to notice more than a few where there may be great numbers. Thus it is that only where pretty general agreement obtains, or where there is an evident gradation from one region to another at some distance, that these reports can be wholly relied upon. This does not mean that the accuracy of any ob- 
as well as those of nomenclature, making the call for a revision all the more imperative. The changes in the physical features incident to the fuller settlement of the state have been attended by changes in the whole fauna, the bird population changing with the rest.

Keenly feeling the need for a state catalogue of our birds which should embody the latest results of field work and conform to the adopted system of nomenclature, the writer appealed to the Ohio State Academy of Science, at its meeting in December, 1900, and found ready sympathy in the plan for a revision. A liberal portion of the McMillin fund was placed at his disposal for the purpose of prosecuting the work, and it is largely that substantial help which makes it possible to present the finished report at this early date. With this fund it was possible to mail upward of two hundred lists of birds of probable occurrence to different parts of the state for reports from local bird students, and to visit several little known regions of the state for the purpose of studying the bird fauna there at first hand. A list of those who kindly contributed notes and who gave other assistance will be found elsewhere.

The nomenclature adopted in this Catalogue conforms to that of the American Ornithologists' Union Check-List, Second Edition and Supplements succeeding. While this system is not free from faults, and while another revision seems imminent, it is not within the province of this catalogue to anticipate much of such revision. Some questions relating to the validity of species and subspecies which occur in Ohio await settlement. In these few cases I have been obliged to use my best judgment respecting the questions at issue. If that judgment proves unsound I trust that the reader will consider the limitations of time and material under which I am obliged to complete this work. 
patient search. Additions to this list would be gladly received.

\section{Relative Abundance.}

In speaking of the relative abundance in Ohio of the several species of this catalaogue I have made use of the more than threescore reports contributed by bird students scattered over most of the state. None of these reports give evidence of any more system in determining the relative abundance than Dr. Wheaton's and his colaborers' work shows, hence the comparisons drawn will seem fair. It is to be hoped that some system for the determination of the relative abundance of birds may soon be brought forward; until that is done we cannot hope for accurate results in this field of knowledge. Dr. Wheaton's observations and those of the persons on whom he relied for information covered only a small fraction of the state, to be sure, but the regions covered may be assumed to have been representative of most of the state at least. It will appear in the discussion of this interesting subject that the author has often quoted himself without the mention of others. Where that is the case the reports received from observers have been too conflicting to be of use, and he has been driven from the unknown to the known. The necessary differences prevailing among bird students as regards the time spent in study, the time of day when the observations are made and the topography covered, furnish no means of comparison unless these elements are known. Field work done at noon only will fail to discover such birds as are quiet during that time. Field work which does not cover certain regions will result in omitting such species as resort only to such regions. Unfamiliarity with notes and songs will often result in the failure to discover certain secretive species, or will fail to notice more than a few where there may be great numbers. Thus it is that only where pretty general agreement obtains, or where there is an evident gradation from one region to another at some distance, that these reports can be wholly relied upon. This does not mean that the accuracy of any ob- 
server is questioned, but it only indicates my own ignorance of the conditions under which he worked.

\section{Definition of Terms Used to Indicate Relative ABUNDANCE.}

Lack of any system for indicating what is meant by the terms "Abundant," "Common," "Tolerably Common," "Rare," and "Casual," makes it necessary for each person using them to define his own system. The terms "Accidental," "Hypothetical," and "Introduced," are defined where they are used, after the treatment of the species in the body of the catalogue.

In a general way, the term "Abundant" signifies that the species to which it is applied are so numerous in individuals as to force themselves upon one's notice. The English Sparrow is the only bird to which this term can be applied the year through. A number of species may be abundant at certain times, as the Robin, Vesper Sparrow, Meadowlark, Wood Pewee, and Bronzed Grackle. These and others may be abundant in certain regions and not in others; or in certain restricted localities and either less numerous or even almost wholly absent from other localities near.

A species is regarded as "Common" when a considerable number of individuals may be found without much effort or much expenditure of time. In the use of this term account must always be taken of the habits of the species to which it is applied. Thus, the Oven-bird may properly be entered as common in a region if it be remembered that it is strictly a woods bird. "Common in woods" would be the accurate designation.

"Tolerably Common" is used to indicate the fact that the individuals of the species designated are so few that they must be searched for under normal conditions, and yet present in the region. The Blue-gray Gnatcatcher is a fair example in all parts of the state which I have visited.

"Rare" is the term reserved for a species which is represented by so few individuals that a record of its occurrence is regarded as unusual. In Lorain county the Golden Eagle 
is rare, because one or two records of its appearance in a year is all my books show.

"Casual," as used in this catalogue, means that the species to which it is applied visits the state only under unusual circumstances. Thus, the Great Gray Owl could not be expected to reach Ohio except during an unusually severe winter when its food supply north failed. Casual stands close to accidental. A Red-tailed Hawk would be casual in a small city park, because that park lies within its range in the surrounding region. A Bullock Oriole would be accidental there because its home is in regions far removed.

In the use of any of these terms except "Casual," account must be taken of the habits of the birds. The Red-winged Blackbird may be abundant in the marshes of any county, but practically absent from the rest of that county. In the body of the work I have endeavored to indicate what are the regions preferred by the different species. Account must also be taken of the size of the birds to which the terms are applied in each instance. Thus a dozen Redtailed Hawks in a township would make that hawk appear almost abundant, while a dozen Chipping Sparrows or Robins in that same township would be almost rare for the species.

Some prophet must arise who will be able to develop a system of relative terms for general use. Such a system is greatly needed in the further development of the department of field ornithoiogy.

\section{BREEDING.}

Not the least difficult of the problems presenting themselves for solution has been that relating to the breeding of many species within the state. So little was known of the general breeding range of many species when Dr. Wheaton completed his work, that it is not strange that he should have regarded as "probably breeding in the northern parts of the state" several species whose breeding range lies well to the north. It is also more than probable that several species which remained to breed before the state became 
so well settled, no longer do so. Remembering the almost total lack of information regarding the southward migrations of many species at that time, we can readily understand how even such keen observers as Drs. Wheaton and Kirtland should have been led to regard as breeding within the state some species which were found in late July. Now we know that they are the vanguard of the southward moving host. We also know that the presence of individuals of a species in summer is not prima facie evidence of its breeding, because many unmated birds wander about considerably, and wounded water-birds may be unable to complete their journey and yet be unable to breed where they are obliged to remain. Nor does the author regard the presence of young which the parent or parents are still feeding positive evidence of breeding, if the occurrence lies close to the state border, because it is well known that many young birds which are still largely dependent upon their parents for food are able to fly considerable distances. Such evidence, however, would be strongly probable of breeding. It should not be necessary to actually find a nest with either eggs or young to establish a breeding record. The continuous presence of an evident pair of birds during the season when they would normally breed, in any given restricted region, ought to be taken as clear evidence of the breeding of that pair. It is frequently not possible to find the nest and examine its contents.

The presence in the north of individuals of a species whose normal range lies well south of such occurrence does not indicate that the species breeds in that northern region. During the migrations and after the breeding season individuals may wander considerable distances from their normal breeding places. While the conclusions here reached are by no means to be considered final, they are at least conservative. It may very likely be that some of the warblers supposed to cross Lake Erie to breed will yet prove summer residents on this side. In editing the notes contributed on the breeding of our birds some records have been withheld because of the lack of positive evidence. 
Food.

An effort has been made to indicate what constitutes the food of the birds which spend much time in the state. In many instances this has been done under the discussion of the individual species, where the species seems to have a strong influence upon agriculture or other economic interests, and where the food differs in some important respects from that of the other members of the group. When the group is not an important factor, or the food of the species is much the same throughout the group, a discussion will be found under the heading of the whole group. Information upon the food habits of the birds has been gleaned from various sources, acknowledgment of which will be found elsewhere. An effort has been made to acquaint the reader with the facts so far as they are known, and thus to show what species are injurious and what beneficial to our interests.

\section{Migration.}

The subject of the migrations of the birds. into and across Ohio has not received sufficient careful attention to warrant tabulation of the dates of appearance and disappearance of such species as migrate, nor any plotting of the routes of migrations most generally followed. It is true that several voluntary observers have worked faithfully and well with the time at their disposal, and the results have greatly extended our knowledge of the migrations, but their time and means have been too limited for exact results. They have made possible general statements, however, which will indicate the times of appearance and disappearance and the general routes of movement across the state. These general results are given in this catalogue.

\section{RANGe in OHIO.}

The present Ohio range of the different species has been largely taken from the numerous reports received, supplemented by published records and by the writer's work at 
Oberlin and in the several regions of the state visited since the preparation of this catalogue began, two years ago. In accepting records for the state and also for the different counties the following rule has been adopted: In order to have a place on the state list a specimen of the species must have been captured and preserved for some time where it could be critically examined. In order to have a place on a county list a species which is rare or casual or accidental in that county must have had a specimen captured and critically examined, or, if a conspicuously marked species, must have been seen under the most favorable conditions by one familiar with that species. This rule has necessarily resulted in the elimination of some species from some of the lists handed me, and has relegated to the state Hypothetical List some species reported on insufficient evidence as occurring in the state. I submit, however, that it is a fair rule, one which will safeguard our work. It is far easier to add a species to such a list than it is to eliminate it after it is wrongly placed there.

\section{TOPOGRAPHY.}

"The state of Ohio is situated between $38^{\circ} 25^{\prime}$ and $42^{\circ}$ north latitude and $80^{\circ} 30^{\prime}$ and $84^{\circ} 50^{\prime}$ west longitude. . . . . It is thus the most southern of the northern tier of states, its northern border corresponding in latitude with the southern border of Michigan and New York. Its extreme length is, from east to west, about 220 miles, its greatest width from north to south about 210 miles. Its area is approximately 40,000 square miles (41,060: land, 40,760; water, 300.)" (Wheaton.) About three-fourths of the state is under cultivation, and of the remaining fourth nearly all is woodland. "Before cultivation a few small prairies in the western and central portions of the state interrupted the general woodland." The disappearance of the forests has resulted in the almost total extermination of a few birds, a marked decrease in the numbers of a large number, and an influx of a few species which live in the open fields. 


\section{Drainage.}

"Two-thirds of the state may be considered as forming a part of the great Mississippi Valley, while about the northern third is in the basin of the great lakes. The water-shed which divides the streams flowing into Lake Erie from those tributary to the Ohio, traverses the state from near the north-east corner in a south-westerly direction as a low ridge the greatest elevation of which is nowhere more than 1400 feet above the sea. This water-shed is lower in Ohio than in Pennsylvania and New York." (Wheaton.)

\section{Elevations.}

The surface of Lake Erie is 573 feet above the ocean. During low water the Ohio river is about 426 feet above the ocean at the extreme south-west corner of the state, near Gravel Pit, rising to $68 \%$ feet at Wellsville in Columbiana county. The Ohio river at its lowest point is thus 147 feet below the surface of lake Erie. The variations in the general surface of the state range from those given above to $\mathbf{1 5 4 0}$ feet, which elevation is reached in Logan county a short distance east of Bellefontaine, where two hills rise, the one to 1500 the other to 1540 feet above tide. A hill in Richland county reaches an elevation of 1475 feet. Nowhere else does the state reach 1400 feet elevation. It will thus be clear that nowhere does altitude play any important part in the distribution of the birds.

\section{ERosion.}

The lake Erie drainage plain is generally a gradual slope northward, with gorges cut into the underlying shale and rock by the larger streams, but without hills of any consequence. The northern and western parts of the Ohio river drainage plain is also level, but growing rougher as the streams descend and enlarge, reaching a maximum of roughness in the south-eastern and southern parts of the state. The unglaciated region presents the greatest erosion and consequently the highest ridges and deepest valleys. Here the streams have cut completely through the upper coal strata. 


\section{RIVERS.}

Only two of the rivers which flow into Lake Erie are of much importance topographically - the Maumee at its western end, and the Grand, near the eastern border of the state. Between these the Portage, Sandusky, Huron, Vermilion, Black, Rocky, and Cuyahoga form greater or lesser valleys, and more or less extensive swamps at their junction with the lake. The principal tributaries of the Ohio are the Muskingum, Scioto, and Miami, and their tributaries, penetrating well into the northern third of the state. They are important highways for the birds in their migrations, and several species belonging to the southern counties follow the courses of these rivers farther north than they venture elsewhere.

\section{LAKES.}

Natural lakes of any considerable extent are lacking, but within the drift area in the north-east numerous small glacial lakes are scattered. Four reservoirs built by the state to supply the system of canals, furnish inland waters for many species as feeding and nesting places. St. Mary's or Grand reservoir, situated in Mercer and Auglaize counties, with an area of 17,000 acres, is the largest; the Lewiston, in Logan county; the Loramie, in Shelby; and the Licking, in Licking, Fairfield, and Perry counties, are of smaller dimensions. The marshes which have formed in and around these reservoirs support as abundant swamp life as the delta marshes at the lake shore.

\section{The Birds and the Water Bodies.}

On the south the Ohio river exerts a marked influence upon the bird fauna of that part of the stațe. Being a main tributary of the great Mississippi river, and extending in a somewhat northerly direction from that great thoroughfare of the birds, it receives its portion of the northward moving host each spring. The course of the Ohio river is so little varied in character that it is not strange that some species with somewhat southern tendencies should wander along 
its course and unwittingly reach a higher latitude than elsewhere. The river itself has, for the most part, little of the character which entices swamp breeders to its shores. While water birds follow its course they do not tarry to breed there, but pass northward.

On the north Lake Erie is a factor to be reckoned with. It acts as a balance between the extremes of cold in winter and heat in summer, thus maintaining a more even temperature at any time of year, preventing the sudden changes which are so dangerous to both plant and animal life. Its chilling spring influence holds vegetation back until time for it to come forth, and by its warm breath in fall it wards off early frosts. Recognizing this influence upon vegetation, we are prepared for the appearance of some of the more southern breeding birds along the shore of the lake, and for the presence all winter of some of the northern species which ordinarily winter much fartner south.

It has already been stated that marshes scattered sparingly along the lake front, usually where streams enter the lake, afford breeding places for many species. The archipelago lying north of Sandusky also affords suitable summer homes for many species not found breeding elsewhere in the state. Wherever clay banks front the water Bank Swallows and Belted Kingfishers nest in numbers.

\section{Climate.}

For a detailed discussion of the climatic conditions of Ohio the reader is referred to a paper on "Some Climatic Conditions of Ohio," by Mr. Otto E. Jennings, in the Ohio Naturalist for January, 1903. It is sufficient to say here that the mean range of temperature, which is $49^{\circ} \mathrm{F}$. in the north and $55^{\circ} \mathrm{F}$. in the south, and the much greater depth of snowfall in the extreme north-eastern corner of the state, are the principal factors which exert any marked influence upon bird life. A number of species are not only more common in the warmer southern counties, but several never reach even the middle of the state. Greater snowfall means covered food in winter, and consequently fewer birds during 
the period of snow. The rapacious birds, especially, go where food is more easily obtainable during the winter months.

\section{Faunal Areas.}

"By far the largest part of the State is strictly Carolinian in its faunal characters; a small portion, the north-eastern corner, is as emphatically Alleghenian." (Wheaton.) Dr. C. Hart Merriam, in "Life Zones and Crop Zones, of the United States," 1898, shows clearly the extent of this arm of the Alleghenian fauna, so far as plant life is affected. I have attempted to indicate this area on the accompanying map. Topographically there seems to be nothing which indicates this difference. It is possible that the influence of the strictly Alleghenian region flows over into Ohio to that extent without any attendant local conditions of topography. A strong hint of the reason for it iles in the much greater snowfall over a large part of this Alleghenian area. The fact that the Hooded Warbler, Worm-eating Warbler, Kentucky Warbler, Golden-winged Warbler, White-eyed Vireo and Summer Tanager invade this area to breed, several of them reaching the lake shore in Ashtabula county, and do not breed as far north anywhere else in the state, would seem to indicate that the conditions which so strongly affect plant life have little or no influence upon these birds. They belong in the Carolinian Fauna.

In northern Ohio there seems a strong tendency toward the Transition Zone, and in the south a strongly typical Carolinian Fauna in the Upper Austral Zone. Thus the Bobolink breeds plentifully all over the northern third of the state, but is scarcely found in summer south of the 40 th parallel. Wilson Thrush also breeds north but is absent in summer south. The Black and Common Terns are found only at the lake shore in summer, but the Carolina Wren and Cardinal nest sparingly, but in increasing numbers, even to the lake shore. South of the 40th parallel, except in the extreme north-east, the Kentucky Warbler and Summer Tanager spend the summer. 
Careful scrutiny of Dr. Wheaton's work will make apparent to any one that there has been a very perceptible movement of many species northward or north-eastward during the last two decades. Several species known then to breed near the lake shore clearly do not breed there now, or if at all very rarely. Several species which did not reach the lake shore then are regular breeders there now. Some species which were confined to the southern border of the state twenty years ago have now reached the central counties, or pushed even farther north-eastward. Bewick Wren, at least, has invaded the state from the south-west. There is some indication of an invasion of the Blue Grosbeak and Nonpareil soon. In winter, we in the north now have Robins and Bluebirds with us in small numbers, where seven years ago none remained. The temperature is not changing, but the birds are gradually developing into hardier animals.

The species involved in this north-eastward movement may be mentioned. Of the warblers: the Prothonotary, Worm-eating, Golden-winged, Chestnut-sided, Magnolia, Kentucky, and the Hooded. Besides these the Summer Tanager; White-eyed Vireo; Pine Siskin; Lark Sparrow; Dickcissel; Cardinal; Carolina Wren; Bewick Wren; Turkey Vulture; and Wilson Snipe. These are the species most affected. It is more than likely that the whole bird host is gradually shifting northward as the weaker ones perish, leaving only the hardier individuals to occupy the arena of daily strife for existence.

\section{From Whence Birds Have Come Into Ohio.}

Birds seem to have appeared upon the earth during the lower Jurassic or possibly even during the upper Triassic times in the world's history. No fossil birds of these times have been found in Ohio, yet it is not impossible that such occurred in the region now named Ohio. However that may be, it is certainly true that the great ice invasion from the north, marking the close of the Tertiary Period and the 
beginning of the Quaternary, with its revolutionary changes of climate from almost universal tropic to frigid conditions over the northern half of the northern hemisphere, drove all life out of what is now Ohio. We are therefore concerned only with the reappearance of the birds in the region.

A glance at the accompanying map will indicate the extent of the ice-cap over Ohio. It will be noticed that the south-eastern counties escaped with nothing more than flooding by water in the lowlands when the ice-cap began to recede by melting. It will also be clear that the whole of the state must have been frigid during the most of the year, with perhaps short periods of freedom from snow and ice when the sun was highest in mid-summer. Clearly the conditions were not favorable anywhere in the state then for breeding. Such birds as survived the changes occasioned by the ice invasion, the crowding into the tropics, and the necessary change of diet, must have remained well south of the ice barrier for long periods.

As the ice-cap began to recede in consequence of another change of climate to warmer, the birds, under the necessity of securing more favorable conditions for breeding, must have pushed northward to the limit of the ice, only to be forced south with the approach of winter. With the recurrence of summer and the further recession of the ice these annual migrations would extend farther and farther northward, and the instinct for regular migrations be formed.

This being true, it is clear that the reoccupation of Ohio must have been from a southerly direction. But since the mountains lying eastward and southward now form a considerable barrier to the migrations of the birds, it is likely that they did to an even greater extent then, since time has served to lessen their height. Remembering, also, that birds follow large features of topography in their annual migrations, like river valleys and coast lines, it will seem more than likely that the Ohio tributary of the great Mississippi river served as a highway for the birds living at the close of the Glacial epoch as it does to-day. We are therefore safe in assuming that the first invasion of the region 
which is now bounded as Ohio came from the south-west. This is made clearer when we know that the species which have come into the state during the last twenty years to become regular summer residents, have come from the southwest or west. Of the thirteen species regarded as accidental within the state seven must have come from the south-west or west, while five may have come from the east or northeast, at least two of which were pretty clearly driven out of their course by severe storms.

The species which have come into the state since Dr. Wheaton finished his catalogue, or which were not known to him, at least, are as follows: From the south-west and west: Prairie Horned Lark, Henslow Sparrow, Nelson Sparrow, Bachman Sparrow, Little Blue Heron, and Black Rail. The following species have been found as migrants, and can hardly be classed as invaders in the true sense: Parasitic Jaeger, Barrow Golden-eye, American Eider, and Long-billed Dowitcher. Caspian Tern is probably a wanderer from the south.

The following species, known to Dr. Wheaton, have considerably extended their range eastward and north-eastward: Lark Sparrow, Grasshopper Sparrow, Dickcissel, White-eyed Vireo, Prothonotary. Warbler, Worm-eating Warbler, Golden-winged Warbler, Kentucky Warbler, Hooded Warbler, Carolina Wren, Bewick Wren, and Carolina Chickadee.

It has already been hinted that there is strong evidence for the belief that several species which earlier ornithologists reported as breeding in the north-eastern counties have ceased to do so, going farther north to spend the summer now. This north-eastward movement can hardly be due to settlement of the country in later years, but rather seems in direct accord with the movement in the same direction of the several species enumerated above. Dr. Merriam shows that a tongue of the Lower Austral life zone reaches about the middle of southern Indiana along the course of the Ohio river. The strong tendency of the birds to follow the course of the Ohio until they reach a latitude considera- 
bly north of their normal summer range in Ohio, seems to indicate that this Lower Austral extension may be approaching our southern border, as far as the birds are concerned. This impression is emphasized by the numerous unconfirmed reports of the occurrence of the Nonpareil and Blue Grosbeak in the vicinity of Cincinnati. A further indication of the tendency of the birds, in the latitude of Ohio, to move gradually northward with their breeding range, is shown in the increasing number of species which remain during the entire winter. It indicates that hardier individuals are gradually being developed. Since Ohio lies near the northern border of the breeding range of several species, and just above the northern range of some others, we may expect that the hardiest individuals of such species will gradually invade regions to the north of their range which have not known them hitherto. This law of differentiation is recognized in a practical manner by those who see sub-specific differences between the individuals of certain species which habitually remain well south to breed and those which habitually push well north to breed. This seems to be one of the methods for the development of species.

The appearance of northern breeding birds in the state in winter cannot properly be classed as invasions, because they are forced south by the stress of hunger, and return at the first opportunity. It seems clear that during the migrations of the species which breed north of the state, the movement of species in the western end of the state is a little west of north, and in the eastern part of the state a little east of north. While Lake Erie is not an insurmountable barrier to most species, they seem to prefer not to cross it directly or at all if possible. I have repeatedly seen Killdeers and Meadowlarks strike out boldly for the Canada side, with a favorable wind, only to turn back before they had passed out of sight. It is more than likely that many individuals of the species which migrate by day pass around the ends of the lake, or cross at Sandusky. 


\section{SOURCES OF INFORMATION.}

In the preparation of this catalogue the author has received much valuable assistance from many sources. $\mathrm{He}$ has freely consulted first of all Dr. J. M. Wheaton's great work, and has taken from it many facts. Cook's "Birds of Michigan," Butler's "Birds of Indiana," Warren's "Birds of Pennsylvania," Ridgway's "Birds of North and Middle America," and Nehrling's "Our Native Birds of Song and Beauty," have proved valuable helps in many ways. Without the material support and hearty coöperation of the Ohio State Academy of Science, particularly its committee having in charge the McMillin Fund for research, this catalogue would not have appeared at this time. To Professor Albert A. Wright, for valuable and timely suggestions and for help in the selection of a map; and to Rev. W. L. Dawson, for coöperation and criticism in the compilation of the list of species, I desire to make grateful acknowledgment here. To all those whose names appear below, who gave freely of their time and knowledge of the birds in their localities, is largely due the approximation to completeness of this catalogue. Many have gone out of their way to help the work along. With such an enthusiastic company of friends there is great hope for the future of our native birds.

\section{CONTRibutors.}

The following persons have returned lists of the birds of their localities checked upon provisional lists which were furnished for that purpose:

Allen-Homer C. Bennett, M.D., Lima.

Ashland-C. L. Metcalf, McZena.

Ashtabula-W. P. Holt, Rev. J. M. Keck, Geneva, Robt. J. Sim, A. W. Galpin, Jefferson.

Clark-Leander S. Keyser, Springfield.

Columbiana-T. C. Randolph, J. W. Suliot, Salem.

Crawford-Hiram B. Sears, Bucyrus.

Cuyahoga-A. Hall, Lakewood; Prof. Francis H. Herrick, R. J. Tozer, Cleveland. 
Defiance-Charles E. Slocum, M.D., Defiance.

Delaware-Miss Ida Newell, Prof. Edward L. Rice. Delaware. Erie-R. L. Baird, Prof. E. L. Moseley, R. D. L. Ransom, Sandusky; Carl Tuttle, M.D., Berlin Heights.

Franklin-Rev. W. L. Dawson, Prof. J. S. Hine, Columbus.

Fulton-Thomas Mikesell, Wauseon.

Geauga-Rev. J. M. Keck, Orange Cook, Chardon.

Greene-Eliza G. Rice, Yellow Springs.

Hamilton-Charles Dury, Russell Everett, Laura Gano, F. W. Langdon, M.D., Joshua Lindhal, Morris Peck, C. C. Smith, Francis P. Smith, Cincinnati; R. F. Souter, Bond Hill.

Hardin-George H. Palmer, Kenton; Agnew Welsh, Ada.

Harrison-Harry B. McConnell, Cadiz.

Knox-T. E. Haughey, Academia.

Lake-E. A. Doolittle, V. E. and T. B. Wyman, Painesville; Rev. J. M. Keck, Mentor.

Licking-Irving A. Field, Granville; Raymond Osburn, Vanatta.

Logan-Homer C. Bennett, M.D., Bellefontaine.

Lorain-Lynds Jones, Oberlin.

Lucas-F. H. Burglehause, Miss Lucy J. Retscher, Toledo.

Madison-Max Morse, London.

Mahoning-E. W. Vickers, Ellsworth.

Morgan-E. J. Arrick, C. H. Morris, McConnellsville.

Perry-Rev. Henry Beeman, New Lexington; Geo. W. DeLong, Corning.

Pike-Rev. W. F. Henninger, Waverly.

Portage-Cornelius Baldwin, Nelson; Geo. H. Colton, Hiram;

Roscoe J. Webb, Garrettsville.

Preble-Julia K. Holn, Lewisburg.

Scioto-Rev. W. F. Henninger, South Webster.

Summit-Eugene F. Cranz, Ira; Wm. B. Haynes, Akron.

Union-Lizzie A. Copp, Richwood.

Warren-Anna C. Stenson, Harveysburg.

Wayne-J. G. Black, Scott G. Harry, Harry C. Oberholser, Ethel Dane Roberts, Wooster.

Wyandot-Thos. A. Bonser, Carey; Paul Smith, Upper San. dusky.

In addition to the names mentioned above, valuable notes have been received from Dr. W. H. Fisher, of Cincinnati, from his records of specimens in his private collection, relating to food and the occurrence of many species, and from Mr. E. B. Williamson, giving dates of nesting of many species in various places in the state. Clippings from lo- 
cal newspapers in which birds are mentioned, which have been sent to me by many helpers, are too numerous and the sources from which they came too various to be given indiridual mention here.

Dr. Frank W. Langdon, Mr. Charles Dury and Dr. Josua Lindahl have contributed notes covering a long series of years in the vicinity of Cincinnati and elsewhere in the state; and $\mathrm{Mr}$. Wm. B. Haynes, of Akron, has given special attention to the shore birds of the natural lakes of that vicinity.

Mr. H. C. Oberholser has been good enough to go over the list of species here recorded, making suggestions and comments which have greatly aided me in the final arrangement of the catalogue. His "Birds of Wayne County, Ohio," and Rev. W. F. Henninger's "Birds of Middle Southern Ohio," have been valuable aids in the revision of the work.

In 1891 Messrs. L. M. McCormick and G. D. Wilder prepared a list of the birds of Lorain county, from which I have been able to add not a little to our knowledge of the birds of the northern parts of our state.

To these gentlemen and to all who have given so freely of their time and notes I wish to tender my grateful thanks. They have made a difficult task possible of accomplishment.

In addition to the counties represented upon the list given above, the writer has been able to spend a greater or less time in studying the birds in the following counties: Athens, Fairfield, Gallia, Huron, Lawrence, Medina, Meigs, Muskingum, Ottawa (islands only), Perry, and Washington. The work in all of these counties, except Huron and Medina, was done in company with Rev. W. L. Dawson. At Chippewa Lake, Medina county, Mr. R. L. Baird accompanied me. Mr. Baird has also been associated with me in considerable of the later work about Oberlin. At the Licking Reservoir, which included parts of Licking, Fairfield, and Perry counties, Messrs. E. J. Arrick and Irving A. Field also participated. Several days were spent in the vicinity of Jefferson, Ashtabula county, with Mr. Robt. J. 
Sim. Most of the work in Erie and Huron counties has been without company.

From the foregoing remarks it will be clear that a considerable portion of the state remains to be explored ornithologically, particularly in the south and west. Some persons with considerable leisure ought to be posted along our southern and western borders to watch for invasions of species from Kentucky and Indiana. I earnestly hope that the appearance of this catalogue will mark the beginning of an era of unusual activity in the study of the birds of our - fair state. 


\section{THE BIRDS OF OHIO.}

Order PYGOPODES. Diving Birds.

Suborder PODICIPEDES. Grebes.

Family Podicipidx. Grebes.

This family is represented in our state by three species, one large and two small. The food consists of fish, aquatic insects, crustaceans, batrachians, and considerable aquatic vegetable matter. The grebes pursue the fish under water, using only the feet in swimming under water. A Horned Grebe found on the streets of Oberlin, February 9, 1895, by Mr. H. C. Tracy, had completely filled its gizzard with small rubber bands, probably picked up on the sireet under the supposition that they were worms. The bird was found in an exhausted condition, and soon died.

(The first number at the left is the serial number of this catalogue. The second number, which is in parenthesis, is the present number of the species in the Check-List of the American Ornithologists' Union. The number to the right of the scientific name and authority is the number found in Dr. Wheaton's Check-List, pages 571-584, of his catalogue.)

\section{1. (2.) Colymbus holbellin (Reinh.). $28 \%$ Holbœll Grebe.}

Synonyms: Podiceps grisigena var. holbœlli, P. holbœlli, P. grisigena.

American Red-necked Grebe, Red-necked Grebe.

Kirtland, Ohio Geol. Surv., 1838, 166, 187. (Podiceps rubricollis.)

This is a rare and irregular winter visitor and migrant, upon almost any of the Ohio lakes, reservoirs or rivers. There have been fewer records since Dr. Wheaton's catalogue was printed than before. 
2. (3.) Colymbus auritus Linn. 288. Horned Grebe.

Synonyms: Dytes auritus, Podiceps cornutus.

Audubon, Orn. Biog., III, 1835, 429.

While this grebe is not common during the migrations it can hardly be called rare in most parts of the state. It is somewhat regular as a migrant, but may be found during the winter. Companies of a dozen or more individuals in full spring dress are not infrequent on Lake Erie. During the southward migration there is a strong tendency for the birds to occur two at a time on the smaller waters. The report of the breeding of this species in Ottawa cointy has not been confirmed.

This grebe is as good a diver as the more familiar Piedbilled, for which it is often mistaken. The slenderness of the bill should always easily distinguish it from that species.

In the migrations the Horned Grebe reaches Oberlin about the middle of April and remains until about the first of May. It returns early in October and tarries until ice forms on the ponds, and may be found at any time during the winter about open water.

\section{3. (6.) Podilymbus podiceps (Linn.). 289. \\ Pied-billed Grebe.}

Synonyms: Podiceps carolinensis, Colymbus podiceps.

Pied-billed Dabchick, Thick-billed Grebe, Dabchick, Dipper, Didipper, Diedapper, Water-witch, Hell-diver, Devil-diver. Kirtland, Ohio Geol. Surv., 1838, 166, 187.

This is the most familiar grebe in Ohio, known by a diversity of names to suit the experiences of each individual hunter. However, the modern shot-gun or rifle is too quick for him. To be sure he sometimes succeeds in dodging the lead thrown at him, but far oftener he falls a victim to it, as the breasts which may be seen on hats and in boas too well show.

This grebe nests sparingly all over the state where conditions may be favorable. One could hardly call the species 
common anywhere, but individuals are to be found during the spring and fall months, on almost any body of water a half acre in extent.

Lorain county dates for spring appearance fall within the last week of March, and the departures during the second week in October.

\section{Suborder CEPPHI. Loons, Auks, Murres etc.}

Family Gavinde. Loons.

Three species belonging to this family inhabit Ohio more or less regularly. Only one species, the Loon, is regular in its appearance, the other two reach the state only in severe winters. The food is similar to that of the Grebes, with a larger proportion of fish, probably, and somewhat less of vegetable matter.

4. (\%.) Gavia imber (Gunn.). 290. Loon.

Synonyms: Colymbus torquatus, C. imber, C. glacialis, Urinator imber.

Great Northern Diver, Common Loon. Kirtland, Ohio Geol. Surv., 1838, 166, 186.

The Loon is no longer a common bird anywhere in the state, but it is not infrequently seen during the migrations on the larger waters. It is apparently a rare summer resident in the region of Sandusky and Toledo, and possibly elsewhere along the lake shore.

At Oberlin it has been seen in late April and early October, but no definite dates of migration can be given. Rev. Mr. Henninger has found it as late as the first of May at Piketon.

5. (9.) Gavia arctica (Linn.). 291. Black-THRoATEd LoQN.

Synonyms: Colymbus arcticus, Urinator arcticus. Black-throated Diver.

Wheaton, Ohio Geol. Surv., 1882, 565. 
This loon is casual as a winter visitor in the state. There have been a number of specimens captured sirice that recorded by Dr. Wheaton, which was captured neat Kelley's Island instead of in Sandusky Bay, Mr. Roscoe J. Webb, who secured the specimen from Mr. Crane in whose collection it was, tells me.

\section{6. (11.) Gavia lumme (Gunn.). 292. Red-throated Loon.}

Synonyms: Colymbus septentrionalis, Urinator lumme, Colymbus lumme.

Red-throated Diver.

Wheaton, Ohio Agri. Rep. for 1860, 371, 379.

This loon is everywhere rare in the state. It has been taken at Cincinnati, according to Mr. Dury and Dr. Langdon, and at Wheelersburg, Scioto county, by Rev. Mr. Henninger. It is rare on Lake Erie. No dates of migration can be given, but it is probably to be found in late March.

\section{Order LONGIPENNES. Long-winged Swimmers.}

Family Stercoraridde. Skuas and Jaegers.

Two species of this small family reach our state more or less regularly, but are rare everywhere. They are the birds of prey among the gulls and terns, getting a large part of their living by forcing the gulls and terns to drop their catch of fish, thus stealing it from them. It is not clear whether these birds ever eat the garbage thrown out from cities into the ocean; if hard pressed for food they might do so.

7. (36.) Stercorarius pomarinus (Temm.). 286. Pomarine Jaeger:

Synonyms: Stercorarius pomatorhinus, Larus pomarinus. Wheaton, Ohio Geol. Surv., 1882, 545.

The records of this rare species are as follows: H. E. Chubb, Cleveland, fall of 1880 (Wheaton; 1882); E. L. 
Moseley, Sandusky, Oct., 1889 (Cook, Birds of Michigan, 26) ; A. Hengartner, Lorain, date not known. It is likely to be found on any of the larger waters with flocks or companies of gulls.

\section{8. (3\%.) Stercorarius parasiticus (Linn.). - Parasitic Jaeger.}

Synonyms: Larus parasiticus.

Smith, Raymond W., Journal Cin. Soc. Nat. Hist., XIV, 1891, 107.

The specimen here recorded was captured near Lebanon, at the close of a week of very stormy weather, in the latter part of March or the early part of April, 1880. Name of captor not given. It was given to Mr. J. E. Gould, who preserved it in his collection. This appears to be the first published record.

E. L. Moseley reports three specimens preserved in local collections in Sandusky as follows: Oct. 6, 1895; Sept. 13, 1899 ; also 'a Jaeger probably of this species Sept. 20, 1889,' Frey. There is a specimen of this species in the collection of Mr. A. Hengartner, Lorain, which Mr. Hengartner shot near Lorain on the lake shore.

Another specimen is recorded by Prof. F. M. Comstock, in The Auk, XIII, 1896, 171, captured near Sandusky, in November, 1895. Prof. Corsstock also mentions a record in the Cleveland Academy of Science Proceedings, by Dr. Kirtland, of a specimen probably of this species captured at the mouth of Rocky River, in November, 185\%. Volume and date of the publication not given.

Family Laride. Gulls and Terns.

Sub-family LARinæ. Gulls.

The gulls differ from the terns in generally larger size and in their manner of feeding, as well as somewhat in the food eaten. There are two gulls regularly found in the 
state at some time of the year, and five which appear occasionally.

While flying over the water in search of food they hold the head horizontally, so that the bill is in a line with the body. They do not plunge into the water for a fish or other food, but settle upon it, or take fish or other food from the surface. They catch fish alive, eat dead fish which may be thrown upon the shore by the waves, and eat greedily of the garbage thrown out from coast cities. The smaller gulls may also eat some insects. Gulls often follow in the wake of ships and snatch any morsel of food which may be thrown into the water.

As scavengers the gulls take first rank because they are the most numerous birds along our coasts. The! congregate about the garbage scows in great numbers arid prevent garbage from washing ashore to pollute earth and air. The laws for their protection should leave no room for a doubt as to their meaning in the mind of any one.

\section{9. (43.) Larus leucopterus Faber. $2 \% 4$. Iceland Gull.}

Synonyms: White-winged Gull.

Wheaton, Ohio Agri. Report, 1860, 370, 379 .

Besides the record which Dr. Wheaton has left us, of the capture of two or three specimens in Cleveland harbor, on the authority of $\mathrm{Mr}$. R. K. Winslow, the only record is for Lorain, Dec. 22, 1888, on the authority of Mr. L. M. McCormick. A specimen was captured near Lorain on the lake, and preseved in the Oberlin College museun.

\section{0. (4\%.) Larus marinus Linn. 275. \\ Great Black-backed Gull.}

Synonyms: Saddle-back, Coffin-carrier, Cobb. Audubon, Orn. Biog., III, 1835, 98.

Dr. Wheaton's records for this gull are admittedly weak, and I am therefore glad to strengthen them by one actual capture and one other record which is hardly open to ques- 
tion. Mr. E. W. Vickers reports "One found dead floating among ice in the creek near Canton." Rev.W. F. Henninger adds another record for Pike county, March 21, 1901. (Wilson Bulletin No. 40, 1902, page 79.) Individuals should be found occasionally on Lake Erie during the winter, and wanderers might occasionally reach Kentucky.

\section{1. (51.) Larus argentatus Brünn. 276. Herring Gull.}

Synonyms: Larus argentatus smithsonianus.

American Herring Gull.

Audubon, Orn. Biog., III, 1835, 98.

It is, perhaps, not quite true that this gull is a resident in the state in spite of the fact that birds have been seen on the lake shore during every week in the year, because there are no breeding records. Probably the summer birds were wandering males or unmated birds. It is a common bird locally on the larger streams and lakes during the mig:ations, but does not seem to be a winter resident upon any of the inland waters, except possibly the Ohio river.

The Lake Erie flocks are much larger after the middle of March than during the winter. Only during the period when the lake is well filled with ice are the numbers few. During the severest weather they remain near the fish houses or follow the ice cutters, unless there be rifts of open water not far out.

\section{2. (54.) Larus delawarensis Ord. $27 \%$. Ring-billed Gull.}

Synonyms: Common American Gull.

Audubon, Orn. Biog., III, 1835, 98.

I have looked for this gull in vain. It is reported as rare everywhere in the state. What Dr. Wheaton says of it would indicate that even as he wrote in 1882 , the numbers were growing considerably less. There appears to be no evidence of its breeding within the state. It is possible that several of the gulls formerly nested on the islands within 
the international boundary, before they were so fully settled, but positive evidence of the breeding of this species is lacking.

13. (60.) Larus philadelphia (Ord.). 278. Bonaparte Gull.

Synonyms: Larus capistriatus, L. bonapartii, Choicocephalus philadelphia, Sterna philadelphia.

Bonaparte's Rosy Gull.

Audubon, Orn. Biog., IV, 1838, 212.

This is the most common small gull, but it is only locally common during the migrations. It is said to breed on Gull Island in Lake Erie, but I have been unable to verify this statement. It was not found on the small islands north of our boundary. Migration dates are unsatisfactory and irregular. The species probably reaches the state in late April.

14. (62.) Xema sabinit (Sab.). 279. Sabine/Gull.

Synonyms: Larus sabinii, Xema sabinei.

Fork-tailed Gull.

Wheaton, Ohio Agri. Report, 1860, 371, 379.

This record is apparently based upon a single specimen in immature plumage captured in Cleveland harbor by $\mathrm{Mr}$. R. K. Winslow, earlier than 1880 , and preserved for a time in the collection of the Ohio Medical College. It had been destroyed previous to 1882 .

\section{Subfamily Sternine. Terns.}

Seven species of terns occur in Ohio, the Common and Black being the only regular visitors in summer. Terns fly with the bill pointing down instead of forward, and the species which we find have a forked tail, while the gulls have a square cut tail. The terns dive into the water for fish. They also eat garbage, and the smaller ones, at least, feed upon insects after the fashion of the swallows. As scavengers they are useful birds, but doubly increase our debt to 
them by feeding upon insects as well. The law against killing or injuring gulls and terns should be carefully observed and rigidly enforced. It is unlawful to possess any part of a gull or tern, as well as any part of most other wild birds, in Ohio.

\section{5. (63.) Gelochelidon nilotica (Hasselq.). 280. Gull-billed Tern.}

Synonyms: Sterna anglica, S. aranea, S. nilotica. Marsh Tern.

Kirtland, Ohio Geol. Surv., 1838, 166, 185.

Its place on our list is based upon the above reference, and upon specimens reported by Mr. R. K. Winslow for the vicinity of Cleveland. It seems likely that more familiarity with this species will prove that it is more regular as a summer visitor than has been supposed.

It has not been found in Indiana nor in the western part of Pennsylvania, but it is reported as breeding on the St. Clair flats.

16. (64.) Sterna caspia (Pall.). Caspian Tern.

Synonyms: Sterna tschegrava.

Imperial Tern.

Dury, Catalogue of Birds, Animals and Fishes, 1886, 4.

Mr. Charles Dury reports specimens from Ross lake, Little Miami river, Ohio river near the Miami river; specimens from which places are in his collection and in that of the Cincinnati Society of Natural History. Prof. Moseley reports it from Sandusky. I have a record for Licking reservoir, May 31, 1902. It must be regarded as a summer straggler in the state.

\section{1\%. (69.) Sterna Forsteri Nutt. 281.} Forster Tern.

Wheaton, Ohio Agri. Report, 1874, 515.

Forster Tern is apparently casual in the state. I have received no records since those given by Dr. Wheaton. The 
difficulty of identifying this tern renders it probable that many occurrences are not noted.

"Mr. Langdon gives it as a rare migrant in the vicinity of Cincinnati, where Messrs. Dury and Freeman note six specimens taken May 4, 1879. My own experience with the bird in this vicinity is limited to a single specimen taken in the fall of 1861 or 1862." (Wheaton.)

18. (70.) Sterna hirundo Linn. 282.

Common Tern.

Synonyms: Sterna fluviatilis, S. wilsonii.

Wilson's Tern, Sea Swallow.

Nuttall, Man., II, 1834, 271.

As its name implies, this tern is the common form during the migrations wherever there is a lake or large stream. It is not everywhere common, however, but may be locally so anywhere in the state. It breeds in large numbers on the islands just north of our boundary, and less numerously on a few of the smaller islands within our boundary. It has been reported as breeding at Sandusky, but no nests appear to have been found there. The birds seen during the summer in the bay and that vicinity are clearly not breeding birds but wanderers in search of food.

During the second week in May it is abundant along the lake front, then usually appearing in loose companies of from ten to fifty or more individuals.

The migrations occur during the first week in May, or the last week in April, and from the first week in August well into October or even November in the souther $n$ counties.

19. (72.) Sterna dougalli Montag. 283. Roseate Tern.

Synonyms: Sterna paradisea.

Paradise Tern.

Audubon, Orn. Biog. III, 1835, 98.

According to the records this species has been found in Ohio less than a half dozen times, once at Cincinnati by Dr. Frank Wr. Iangdon, and the others at the lake shore. 


\section{0. (74.) Sterna antillarum (Less.). 284. Least Tern.}

Synonyms: Sterna minuta, S. frenata, S. superciliaris, Sternula antillarum, Sterna superciliaris antillarum.

Audubon, Orn. Biog., IV, 1838, 175.

The records for this tern are few but well scattered over the state. It appears to be a rare migrant everywhere. I have never seen it at the lake shore. Its routes of migration may be largely confined to the western half of the state.

21. (7\%.) Hydrochelidon NigRa SURINAMEnsis (Gmel.). 285.

Black Tern.

Synonyms: Hydrochelidon lariformis surinamensis, H. lariformis, H. plumbea, H. fissipes, Sterna nigra, S. surinamensis.

Short-tailed Tern.

Audubon, Orn. Biog., III, 1835, 535.

The Black Tern is nowhere as common as the Common Tern, but it is not at all rare as a summer resident in the vicinity of Sandusky and Toledo. I have been unable to find it farther east as a summer resident. While the Common Terns breed upon the islands well up from the water the Black Terns choose the marshes, building a nest on the rotten floating vegetation in the swamps where there is no danger from waves.

The spring migrations occur during the second week in May at Oberlin, but probably a week earlier in the region of Sandusky. I have no records for the departure southward. We found them on the Ohio river late in August.

Order STEGANOPODES. Totipalmate Swimmers.

Family Phalacrocoracide. Cormorants.

One member of this family passes across Ohio, and nested in former years. Cormorants are great fish eaters, and probably eat little if anything else. The Chinese train them to fish for them. 
22. (120.) Phalacrocorax dilophus (Swain). 272. Double-crested Cormorant.

Synonyms: Graculus dilophus, Pelecanus (Carbo) dilophus. Wheaton, Ohio Agri. Report, 1874, 575.

The cormorants are not well enough known to give us much of an idea of their distribution in the state. This one appears to be a rare migrant in the western half, probably, passing across the state without stopping usually, since there is no suitable feeding place except the reservoirs. Dr. Wheaton states that this species may have nested at the Licking reservoir in earlier years. Mr. Dury found it nesting at St. Mary's reservoir more than twenty years ago.

\section{Family Pelecanide. Pelicans.}

Of the three species in this family only the American White Pelican is found in Ohio. This pelican lives upon fish which it scoops up from the water in the capacious pouch hanging to its lower mandible. There is no evidence that it carries either fish or water in the pouch while flying, since its young are fed upon partially digested fish disgorged from its crop.

23. (125.) Pelecanus erythrorhynchos Cmel. $2 \% 1$. American White Pelican.

Synonyms: Pelecanus trachyrhynchus, P. onocrotalus. White Pelican.

Kirtland, Ohio Geol. Surv., 1838, 166, 187.

The pelican is a rare migrant across the state. So conspicuous a bird would be reported generally if it occurred. One was shot at the Licking reservoir about May 15, 1902. It has been seen at Oberlin twice. The records are few and scattering, but seem to indicate that it is confined to the western half of the state. 
Order ANSERES. Lamellirostral Swimmers.

Family Anatides. Ducks, Geese, and Swans.

The members of this order mușt be treated under the subfamily groups.

Subfamily Merginæ. Mergansers.

All three American members of this subfamily occur in Ohio somewhat regularly during the migrations. They are properly designated "Fish Ducks," because they feed largely upon fish, but probably also eat mollusks, crustaceans, frogs, and other aquatic animals to some extent. Dr. Warren states that in diving they use the wings as well as the feet for propulsion. On the surface of the water they certainly use their wings when hard pressed to get away, but are unable to fly up. The flesh of the two larger species is rank and fishy, but the Hooded Merganser is a table delicacy.

\section{4. (129.) Merganser americanus (Cass.). 268. American Merganser.}

Synonyms: Mergus merganser, M. m. americanus, M. ameriicanus.

Merganser, Goosander, Fish Duck, American Sheldrake. Kirtland, Ohio Geol. Surv., 1838, 166, 187.

Both mergansers remain all winter where there may be open water sufficient for feeding. This form appears to be the more common of the two belonging to the genus Merganser. It is found on Lake Erie well into January, but is not found during the period when the lake is ice boundduring the most of February and sometimes the first week of March. It has passed north by the third week in April.

\section{5. (130.) Merganser Serrator (Linn.). $26 y$. Red-breasted Merganser.}

Synonyms: Mergus serrator.

Red-breasted Sheldrake.

Kirtland, Ohio Geol. Surv., 1838, 166, 187. 
This "Fish Duck" is not only less common than the preceding species, but is even rare over most of the state. It is seldom seen during the winter months, but must still be considered a winter visitor as well as a rare migrant across the state. Its occurrences are too few and too scattered to assign migration dates.

\section{6. (131.) Lophodytes cucullatus (Linn.). $2 \% 0$. Hooded Merganser.}

Snyonyms: Mergus cucullatus.

Saw-bill, Topknot, Hooded Sheldrake.

Kirtland, Ohio Geol. Surv., 1838, 166, 187.

While this merganser is rather more numerous than either of the larger species, it is only locally common in the state as a migrant. There are no records of its breeding within our borders. While the others are more frequently seen on the lakes and larger streams, this is a river duck as far as its habits and routes of migration are concerned. I have never seen it except on the smaller streams and ponds. It visits the Oberlin water-works reservoir during the spring, with the hosts of other ducks, but always keeps to itself while resting and feeding. The conspicuous "hood" with the large white patch in its center, furnishes a mark for certain identification of the breeding males.

The Hooded Merganser passes Oberlin about the middle of April. It is seldom seen during more than a week all together.

\section{Subfamily Anatinж. River Ducks.}

This subfamily is represented by an even dozen species and subspecies in Ohio, two of which are accidental in the state. The River Ducks are dabblers in shallow water, turning tail up and immersing only the head, neck, and fore part of the body when feeding. It does not, therefore, follow that they never dive, for they often do. The food of this group is largely vegetable, both aquatic and nonaquatic; weed seeds comprise a good part. The flesh 
of all is considered a great delicacy. The birds do not feed entirely in the water, but may often be found on the land, especially during the summer months.

27. (132.) Anas boschas Linn. 24\%.

Mallard.

Synonyms: Anas domestica.

Kirtland, Preliminary Report, Ohio Geol. Surv., 1838, 67.

The Mallard is locally common during the nigrations, but it is almost absent from many localities. It breeds irregularly from the southern border of the state at least to Columbus, and seems rather more common as a summer resident in the northern half, but is very local in its summer distribution anywhere in the state. It is seldom that anything but small flocks are seen in the migrations. At the lakes and marshes they may be found in greater numbers together. It is probably true that males of this species may be found during the summer much farther south and in many localities in the state where there are no breeding females. The males are wanderers and apparently have no care for the brood.

The migrations of the Mallard begin during the first week in March, at Oberlin, and continue well toward the close of the month. Individuals that were clearly migrating have been seen as late as the middle of April. The southward migrations are at their height about the middle of November, but vary with the weather.

28

(133.) Anas obscura Gmel. 248.

Black Duck.

Synonym: Dusky Duck.

Kirtland, Preliminary Report, Ohio Geol. Surv., 1838, 67.

The recent division of this species into two forms makes it doubtful what the status of the two forms for Ohio is. An examination of skins in two collections indicates that this form is the less common in Ohio.

Dr. Wheaton regarded the Black Duck as a casual sum- 
mer resident in the northern parts of the state, but I find no corroborative evidence to that effect. It is more often seen in pairs or singly than the Mallard, and appears to be less wary, frequenting small ponds and streams which the Mallard avoids.

The migrations occur at the same time as the Mallard, with possibly a little earlier return in the autumn.

\section{9. (133a.) Anas obscura Rubripes Brewst. Red-legged Black Duck.}

Henninger, Wilson Bulletin, No. 41, 1902, page 134.

The recent addition of this subspecies to our fanna makes any statement about its range in the state of little value. It seems likely to be found not uncommon during the migrations, probably in company with the Black Duck. Collections seem to indicate that this is the more common form for Ohio, if it does not prove to be the regular migrant to the almost exclusion of the other form. Ohio collections contain both forms.

30. (135.) Chaulelasmus streperus (Linn.). 249. Gadwall.

Synonyms: Anas strepera.

Gray Duck.

Kirtland, Ohio Geol. Surv., 1838, 166, 186.

The Gadwall appears to be rare as a migrant. Reports are not only few but generally unsatisfactory. It is certainly among the disappearing ducks in Lorain county. Prior to 1885 it was one of the market ducks on the lake shore, but it is not seen there now. I have no migration records that will give any idea of the movements of this species.

31. (13\%.) Mareca americana (Gmel.). 251.
Baldpate.

Synonyms: Anas americana.

American Widgeon.

Kirtland, Preliminary Report, Ohio Geol. Surv., 1838, 67. 
This once abundant duck is now common only locally and there only occasionally. It has become wary and hard to approach. In Lorain county I have seen only single individuals and two together, and they on the smaller unfrequented ponds. Lately several have formed the habit of visiting our water-works reservoir, in spite of the fact that it lies well within the town. If it breeds within the state now there is no mention of that fact in the reports received. Dr. Langdon mentions its breeding in Ottawa county.

Migration dates for the spring movements fall within the third week of March for southern Ohio, but almost a month later for Oberlin. The southward movement occurs late in October.

32. (139). Nettion carolinensis (Gmel.). 254. Green-winged Teal.

Synonyms: Anas carolinensis, Querquedula carolinensis. American Green-winged Teal. Audubon, Orn. Biog., III, 1835, 219.

This teal is reported as a common migrant across the state. It is the earlier of the two teals, arriving with the Mallards and other early ducks. I have seen several individuals of this species migrating in flocks of Mallards. It has not yet been found in Lorain county during my studies anywhere but on the lake. None have visited our waterworks reservoir.

33. (140.) QuerQuedula discors (Linn.). 253. Blue-winged Teal.

Synonyms: Anas discors.

Kirtland, Preliminary Report Ohio Geol. Surv., 1838, $₫ 7$.

This is a common duck locally during the migrations, but it is clearly less common than during Dr. Wheaton's time. It may be found on the smaller streams and ponds as well as on the larger rivers and lakes. In Lorain county I have found it only on the small ponds in twos and threes or singly. Flocks are sometimes seen passing northward. 
The spring migrations are late for a duck, occurring during late April, and the fall migrations in October.

Dr. Langdon found it breeding in Ottawa cointy years ago, but there are no recent records of its nesting there.

\section{4. (142.) Spatula clypeata (Linn.) 252. Shoveller.}

Synonyms: Anas clypeata.

Spoon-bill, Broad-bill.

Kirtland, Ohio Geol. Surv., 1838, 166.

From a "very common migrant" this duck has become almost rare everywhere in the state. It has been recorded less than a dozen times, in the last fifteen years, in Lorain county, and then either singly or in small companies. If it once nested in the state it has ceased to do so. Dr. Wheaton inclined to the belief that it would be found nest. ing in the northwestern counties. I have been unable to verify this.

It may be found during March and as late as December. Migration dates are too scattering to give its movements accurately.

35. (143.) Dafila acuta (Linn.). 250.
Pintail.

Synonyms: Anas acuta.

Spring-tail, Sprig-tail.

Kirtland, Ohio Geol. Surv., 1838, 166, 186.

The Pintail appears to be about the most numerous of the ducks sought after by the hunters. It is seen in considerable flocks during both the spring and autumn migrations, and not infrequently stops on the smaller ponds and streams. It is always wary and hard to approach. It sometimes remains all winter in favorable localities, but has not been known to breed.

The migrations of this duck begin late in February or early in March, and may continue until the first week in April at the lake shore. It comes south with the first touch 
of winter, and is gone from the northern parts of the state with the freezing of the streams and ponds.

36. (144.) Aix sponsa (Linn.). 255. Wood Duck.

\section{Synonyms: Anas sponsa.}

Summer Duck, Tree Duck, The Bride.

Audubon, Orn. Biog., III, 1835, 52.

This duck breeds throughout the state in favorable localities. It nests in the woods some distance from water, but must have feeding places within reach of the nest. The young are said to be carried to the water when hatched. There seems to be little difference in numbers during the migrations from those during summer. It can hardly be called a common species, yet it is hardly rare. The first birds appear at Oberlin about the middle of April and are gone by the last of October.

Subfamily Fuligulinæ. Sea and Bay Ducks.

Fourteen species represent this family in our state, some of them being rare. The members of this group dive when feeding, frequently to considerable depths. Their food consists of the seeds and roots of aquatic plants, mollusks, crustaceans, and some fish in winter. Some members of the group dive as readily as the true divers. Most of the species are found in flocks of varying size during the migrations.

3\%. (146.) Aythya americana (Eyt.). 260.

Redhead.

Synonyms: Athya americana, Fuligula ferina var. americana, F. ferina, F. americana.

Pochard, American Pochard.

Kirtland, Preliminary Report Ohio Geol. Surv., 1838, 67.

The Redhead is only tolerably common as a migrant. It visits the ponds and small streams as well as the larger bodies of water. It is a fairly regular visitor to the Oberlin water-works reservoir both spring and autumn. 
Its migrations cover the period from the second week in March to the second week in April, and at the same period in October and November, except that it may tarry even into December in favorable years.

38. (14\%.) Aythya vallisneria (Wils.). 259.

Canvas-back.

Synonyms: Athya vallisneria, Fuligula vallisneria, Anas vallisneria.

Canvas-back Duck.

Kirtland, Ohio, Geol. Surv., 1838, 166, 187.

The delight of the epicure, and therefore hunted down by every market hunter, this duck has become scarce. I have seen it twice in Lorain county in the last ten years, once when it visited the Oberlin water-works reservoir.

It appears to migrate at the same time as the Redhead, but migration dates are too few to make any positive statements possible.

39. (148.) Aythya marila Linn. 256.

Greater Scaup Duck.

Synonyms: Fulix marila, Fuligula marila, Aythya marila nearctica.

Greater Black-head, Big Black-head, Blue-bill, Broad-bill, Raft-duck, Flocking Fowl, Shuffler, American Scaup Duck. Kirtland, Ohio Geol. Surv., 1838, 166, 187.

In my experience this Scaup Duck is about one-fourth as numerous as the Lesser Scaup; that would make it hardly common. There is often one or two of this species in the flocks of Lesser Scaups which visit the Oberlin waterworks reservoir every year. There is no evidence that this species breeds within the state. The birds which may be found on the reservoirs during the summer, while they may be of both sexes, are not breeding, but are no doubt wounded birds unable to migrate. Their bodily condition would make breeding out of the question.

The migrations are rather late, occurring late in March or early in April, and continuing for two or three weeks. In 
the autumn they begin in late October and continue well toward the close of November, or later if the conditions be favorable.

40. (149.) Aythya Affinis (Eyt.). 25. 7 Lesser Scaup Duck.

Synonyms: Fulix affinis, Fuligula affinis.

Lesser Black-head, Little Black-head, Little Blue-bill. Audubon, B. Am., VI, 1843, 316.

This is probably the most familiar duck to residents of Ohio. It is apparently less numerous than the Pintail, but is far less wary and so more frequently seen by the casual bird student or hunter. It seems to prefer the smaller waters, and is a regular and numerous visitor to the Oberlin water-works reservoir. It is a rare summer resident in Lorain county, and has been reported as breeding in Summit county. It probably breeds sparingly in the northern third of the state. Considerable numbers of both sexes of this species were found during the summer on both the Licking and Lewiston reservoirs, but they proved to be crippled birds and were not breeding.

The migrations begin late in March or early in April, and flocks of considerable numbers are seen at Oberlin as late as May 5th. Their return is dependent in large measure upon the weather. The first are usually seen during the second week in October, and some may tarry well into November.

41. (150.) Aythya collaris (Donov.). 258. Ring-necked Duck.

Synonyms: Fulix collaris, Anas collaris, Fuligula collaris, Fuligula rufitorques.

Ring-bill, Ring-billed Black-head, Ring-necked Scaup Duck, Marsh Blue-bill.

Kirtland, Ohio Geol. Surv., 1838, 166, 186.

This duck is little known, and is reported as rare throughout the state. Dr. Wheaton reported it as abundant. I have found it but once in Lorain county, and that once on 
the Oberlin water-works reservoir. It appears to migrate with the other members of its genus, but there is no evidence that it breeds within the state.

42. (151.) Clangula clangula americana (Bonap.). 261.

American Golden-eye.

Synonyms: Clangula glaucium americana, Bucephala clangula, B. americana, Clangula americana, C. glaucium, Glaucionetta clangula americana, Fuligula clangula.

Golden-eyed Duck, Whistler, Garrot, Great-head: Whistlewing.

Kirtland, Ohio Geol. Surv., 1838, 166, 187.

The Golden-eye is hardly common regularly, and frequently rare. It sometimes appears in considerable numbers on the rivers and lakes, and may sometimes be found on the larger ponds. It may remain during the winter in favorable localities under favorable conditions. It has not been seen on Lake Erie during the entire winter, but sometimes remains into January. It does not breed in the state.

The Golden-eye is one of the earlier migrants in spring and later in autumn, migrating with the Mallard and Pintail.

(152.) Clangula islandica (Gmel.). Barrow Golden-eye.

Synonyms: Glaucionetta islandica, Anas islandica.

Rocky Mountain Garrot or Golden-eye.

McCormick, Auk, 1892, 397.

If one could judge from the records, this is an almost unknown bird in Ohio. It is reported from Sandusky Bay, by Prof. E. L. Moseley, and has been taken twice in Lorain county, once by Mr. L. M. McCormick (see above reference) and once by the writer, on the Oberlin water-works reservoir. It should be found during the winter on the waters of the northern part of the state. 
44. (153.) Charitonetta albeola (Linn.). 262. Buffle-head.

Synonyms: Clangula albeola, Bucephala albeola, Fuligula albeola, Anas albeola.

Buffle-headed Duck, Butter Duck, Butter-ball, Dipper, Spirit Duck, Dipper Duck, Butter-box, Hell-diver.

Kirtland, Ohio Geol. Surv., 1838, 166, 187.

The little Buffle-head is common during the migrations, both spring and autumn. It visits the smaller lakes and ponds, where it is oftener seen than on larger waters. It is not wary, trusting to its agility in diving for protection. There is no likelihood that it breeds within the state, but it may remain all winter in suitable localities well sonth.

Its migrations occupy the last week in Marcli and the first two weeks in April. It appears to be less common during its southward migration, which begins early in October and continues well into November, or later.

\section{5. (154.) Harelda hyemalis (Linn.). 263. Old-squaw.}

Synonyms: Harelda glacialis, Anas glacialis, A. hyemalis, Clangula hiemalis, C. hyemalis.

Long-tailed Duck, Old-wife, South-southerly.

Wheaton, Ohio Agri. Report, 1860, 370, 378.

This is a winter duck, sometimes passing to the southern border of the state. It is not at all regular even in the northern part, and does not appear to be governed wholly by weather conditions. During some winters it is decidedly numerous anywhere on the lake front, and may venture well inland upon the smaller lakes and reservoirs, to the Ohio river, and several winters may pass without another visitation. Specimens have been taken from the gill nets off Lorain in five fathoms of water where they had dived for fish and became tangled in the nets and drowned. Several spent the winter of $1901-02$ on the lake shore in Lorain county. 


\section{6. (160.) Somateria dresseri Sharpe. - American Eider.}

Synonyms: Somateria mollissima dresseri.

Davie, Nests and Eggs of N. Am. Birds, 1898, 92.

The spe:imen here reported by Mr. Davie was captured at the Licking reservoir, November 11, 1895, by Mr. William Harlow. I sie specimen is a female and is preserved in the private collection of Mr. Davie.

The fact that this species has been found a number of times well inland makes it necessary to regard it a casual rather than an accidental visitor to the state.

\section{4\%. (162). Somateria spectabilis (Linn.). 264. King Eider.}

Synonyms: Anas spectabilis.

Wheaton, Ohio Agri. Report, 1860, 370, 378.

I have been unable to find any later records for the occurrence of this species in Ohio than those given by Dr. Wheaton in his catalogue of 1882,535 . They are: An immature bird taken at Sandusky bay (?), by Dr. Langdon during the winter of 187\%-8; one found in the Columbus market, November 4, 1880, by Dr. Wheaton; and the statement that a specimen was taken at Sandusky bay and one at Cleveland "many years since," on the authority of Mr. R. K. Winslow.

48. (163). Oidemia americana Swains. 265. American Scoter.

Synonyms: Eedemia americana.

American Black Scoter, Sea Coot, Butter-billed Coot, Hollow-billed Coot.

Merriam, Trans. Conn. Acad., IV, 1877, 127.

There seem to be four records of the occurrence of this species in the state. Licking reservoir, December, 18\%6, in Dr. Theodore Jasper's collection in Columbus ; taken on Portage river by Mr. R. K. Winslow; one taken from a flock of three on Lake Erie, by Mr. H. E. Chubb; Alum 
Creek, Columbus, December 3, 1895, in the collection of Oliver Davie, Columbus.

It seems pretty clear that this is a casual winter visitor.

49. (165.) Oidemia deglandi Bonap. 266. White-winged Scoter.

Synonyms: Melanetta velvetina, Edemia fusca (var.?) velvet. ina, CEdemina fusca.

Velvet Scoter, White-winged Surf Duck, White-winged Coot, Black Surf Duck, Velvet Duck, Sea Coot

Wheaton, Ohio Agri. Report, 1860, 370, 378.

Dr. Wheaton states that Mr. R. K. Winslow recorded the occurence of this duck at Cleveland and Sandusky bay. The records which are based upon specimens captured are: one taken on the Scioto river near Columbus, and an immature bird taken at the Licking reservoir in December, 1876, both specimens having been examined by Dr. Wheaton. There are two specimens in the Oberlin Coliege collection, one taken April 2\%, the other May 3, 1892, by Harry Warden, of Lorain. These specimens wire taken at Lorain.

One might judge from these records that this scoter is a rare migrant across the state, or possibly a winter visitor. It is rare at any rate.

\section{0. (16\%). Erismatura Jamaicensis (Gmel.). 26\%, Ruddy Duck.}

Synonyms: Erismatura rubida, Fuligula rubida, Anas rubida. Black Jack, Bristle-tail, Fool Duck.

Kirtland, Ohio Geol. Surv., 1838, 166, 186.

My experience with this small duck proves that at Oberlin it is almost as numerous as the Bufflehead on the waterworks reservoir. It is seen there regularly every spring and autumn in twos and fours, rarely more, and is even less wary than the Bufflehead. There is no evidence of the breeding of this species in the state. It is reported as not common by most observers. It is probably somewhat local in its distribution. 
They reach Oberlin about the middle of April and may linger until the 10th of May. The return is early in October and some remain a month or six weeks.

\section{Subfamily Anserinæ. Geese.}

There are six species of geese in the state, none of them really common now, none of them breeding here. They are much more terrestrial than any of the ducks, feeding upon grains and the green herbage. In the water they feed like river ducks (by tipping up, searching the bottom of a shallow pool for the roots and fruit of aquatic plants). They fly in regular order with a leader.

\section{1. (169.) Chen hyperborea (Pall.). 243 (part). Lesser Snow Goose.}

Synonyms: Chen hyperboreus, Anser hyperboreus, Chen hyperboreus albatus.

Alaska Goose, White Brant.

There is no published record of this species as an Ohio bird. Reports give it as rare in Allen, Erie, Hamilton, and Perry counties. Everywhere it is reported as rare, and as usually occurring in company with the other species.

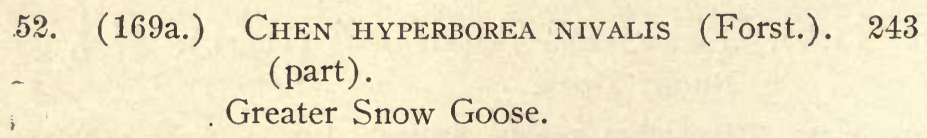

Synonyms: Chen hyperboreus Anser nivalis, A. hyperboreus. Snow Goose, Alaska Goose, White Brant.

Kirtland, Ohio Geol. Surv., 1838, 166, 186.

This larger species seems to be no more common than the last. It is reported from Scioto, Pike, Perry, Hamilton, and Erie counties. These Snow Geese are too conspicuously different from the other geese to make any mistake of identification possible. It is very desirable that specimens in the collections be critically examined to determine the status of each form. 
53. (169.1.) Chen CAerulescens (Linn.). 242. Blue Goose.

Synonyms: Anser cærulescens.

Blue Snow Goose.

Wheaton, Ohio Agri. Report, 1874, 574.

This peculiarly colored goose is not so rare as was supposed before Dr. Wheaton's catalogue called attention to it. It is not a regular visitor to any locality, but may be found anywhere in the state where there is water sufficient to sustain aquatic life and afford feeding grounds. Two were captured on the Oberlin water-works reservoir, October 28, 1896. It is a migrant across the state, the most of the records falling in October.

\section{4. (171a.) Anser albifrons gambeli (Hartl.). 244. American White-fronted Goose.}

\section{Synonyms: Anser albifrons, A. gambelii.}

Laughing Goose, Gray Brant, Speckle-belly.

Kirtland, Ohio Geol. Surv., 1838, 166, 186.

This goose is rare as a migrant across the state, but is reported as a rare winter resident in Hamilton county. Mr. Ridgway states that it frequents open fields and feeds upon the scattered grain and tender blades of growing grain. Little seems to be known of it as a bird of Ohio.

\section{5. (172.) Branta canadensis (Linn.). 245. Canada Goose.}

Synonyms: Bernicla canadensis, Anser canadensis.

Wild Goose, Common Wild Goose.

Audubon, Orn. Biog. III, 1835, 1.

This is the "Wild Goose" of the popular mind. In the vicinity of Oberlin it is not at all common as a migrant. Usually the season's records include one large flock during each migrating period, and possibly a single individual or two. It is resident all winter in southern Ohio, where it remains from November until April. It feeds in the open fields rather than in the water, being very much of a vege- 
tarian. This goose may be domesticated with little difficulty, but measures should be taken to prevent its migration when the season approaches.

The migrations are not regular, but may begin late in February and continue well into April. Few or none are seen in autumn before the first touch of winter drives them south.

56. (172a.) Branta canadensis hutchinsil (Rich.). 245a.

Hutchins Goose.

Synonyms: Bernicla hutchinsii, B. canadensis hutchinsii, Anser hutchinsii.

Lesser Canada Goose, Little Wild Goose.

Wheaton, Ohio Agri. Report, 1860, 370, 378.

Dr. Wheaton admitted this species to his list on the authority of Mr. R. K. Winslow, who stated that several specimens had been taken in Sandusky bay. No specimens seem to have been preserved. A live specimen in the possession of Mr. William Harlow, of Millersport, on Licking reservoir, has been carefully examined by Mr. W. L. Dawson, and proves to belong to this form. It was captured in the wild state and has been domesticated by Mr. Harlow.

\section{Subfamily Cygninæ. Swans.}

Two species of swans are found in the state, both of them during the migrations only. They are seldom scen, except when the weather conditions force them near the ground in their migrations, when flocks may be noticed during the northward movement. Such large birds, with such long slender necks, could not be expected to dive for food. They are not so undignified as to tip up, but simply immerse the head and neck to glean from the surface of the mud bottom. Their food is almost wholly vegetation, but some mollusks seem to be eaten sometimes. 
57. (180.) Olor columbianus (Ord.). 240. Whistling Swan.

Synonyms: Olor americanus, Cygnus americanus, C. musicus, C. columbianus, Anas columbianus.

Common American Swan, American Whistling Swan.

Kirtland, Ohio Geol. Surv., 1838, 166, 187.

During the spring of 1899 this swan was numerous in Lorain county where many were killed by hunters. It is a rare migrant in the state, seldom being seen in its passage unless stopped by stormy weather. Migration records are wanting.

58. (181.) Olor buccinator (Rich.). 241. Trumpeter Swan.

Synonyms: Cygnus buccinnator.

Wheaton, Ohio Agri. Report, 1860, 369, 378; Reprint, 1861, 11, 20.

The Trumpeter Swan is even less numerous than the Whistling, but passes across the state in its migrations. It has been taken on Lake Erie several times within the past ten years. Very little seems to be known of it as an Ohio bird. This swan may remain in the state during the winter.

Order HERODIONES. Bitterns, Herons, Storks, Ibises, Egrets.

Suborder CICONIÆ. Wood Ibis.

Family Ciconinde. Wood Ibis.

The single species comprising this family rarely wanders to the southern part of the state.

59. (188.) Tantalus loculator Linn. 192. Wood Ibis.

Synonyms: American Wood Stork, Colorado Turkey, "Gannet," "Water Turkey."

Wheaton, Reprint, Ohio Agri. Report, 1861, 21.

Apparently the only absolutely unquestionable record of 
this bird's occurrence in Ohio is that of Mr. H. E. Chubb, of Cleveland, who mounted a young male which was captured ten miles west of Cleveland. Dr. Langdon's inferential record should not be omitted. Specimens captured on the Whitewater river in Indiana very likely followed that river to its junction with the Big Miami and so into Ohio.

Suborder HERODII. Bitterns, Herons, Egrets.

Family Ardeides. Bitterns, Herons, Egrets.

Subfamily Botaurinæ. Bitterns.

All the species comprising this group are found in the state. They are strictly swamp haunters, feeding and nesting there. They usually stand quietly and wait for the prey to come within striking distance, when they strike it with the strong, sharp-pointed bill. I have seen them pursue the frog or fish or tadpole. Apparently they eat any small animal which comes in their way in the swamps, except birds.

60. (190.) Botaurus lentiginosus (Montag.). 190. American Bittern.

Synonyms: Botaurus minor, Ardea minor, A. lentiginosus.

Bittern, Indian Hen, Stake Driver, Bog-bull, Thunder Pump, Kirtland, Ohio Geol. Surv., 1838, 165.

The Bittern will not be known to those who do not go into the marshes and swamps. It is seldom seen on running streams, preferring the unfrequented swamps and bogs, feeding in the stagnant pools among the reeds and brush. It is reported as fairly common over the state, but will be absent from places lacking swampy ground, and therefore must be considered local in its distribution in stummer. It is more frequently seen during the migrations than at any other time. While visiting in Medina in May, 1901, while out with a party of bird students on a wet morning: we saw a Bittern in an orchard in the heart of the residence district of the village. It permitted an approach within a rod, and 
even then merely hopped into the foliage a littie closer. Later I learned that we failed to see the young bird which was crouching in the grass. This bird is a summer resident, probably breeding throughout the state wherever suitable places may be found.

The first reach Oberlin late in March or early in April, and the last return south late in October.

\section{1. (191.) ARdetta Exilis (Gmel.). 191. Least Bittern.}

Synonyms: Ardea exilis.

Kirtland, Ohio Geol. Surv., 1838, 165.

This little bittern is more local in its distribution than the last species. At the Licking reservoir it was the most numerous of the swamp haunting birds, but we were unable to find one at the Lewiston reservoir. It nests in the Sandusky bay swamps, and a pair has usually been found at the Oak Point swamps. Elsewhere I have no knowledge of it. The birds are so reluctant to leave their reedy retreats that it is no wonder few are seen by any but the ardent ornithologist. It is likely that this bittern breeds locally throughout the state, but the reports are not positive on that point.

The migrations are late in April or early in May, and the last return south by the middle of September.

Subfamily Ardein A. Herons and Egrets.

Six species of this group are found in Ohio. All of them are wading birds and therefore feed in shallow water. They choose more open water than the bitterns, trusting more to watchfulness and stalking for their food. Their nests are built in trees or bushes instead of in the rushes, and the birds are found among the trees. Their colors do not blend so perfectly with their surroundings. Their food is mucl the same as that of the bitterns. 
62. (194.) ARdea herodias Linn. 185. Great Blue Heron.

Synonyms: Blue Crane.

Kirtland, Ohio Geol. Surv., 1838, 165.

This, the largest of our herons, is being jostled about at an alarming rate as its wooded retreats disappear. It is a summer resident in all parts of the state, but the large heronries once accommodating great numbers of pairs are either greatly reduced or wholly destroyed. I have reports of a great heronry at Richmond, and another, already reduced to half its former size, some eight miles scutheast of Jefferson. The water is being drained off and the trees made into lumber, and the birds must go. In Lorain county half a dozen pairs nest each year, but there is no apparent increase in numbers from year to year. Their nesting retreats have not yet been discovered, so they are likely to remain in peace for some time.

Unlike the bitterns, the herons prefer either running water or stagnant water free from much growing vegetation. The Great Blue feeds mostly from the fish nets in Lake Erie, taking the fish out of the "pounds." Batrachians are captured in the streams and ponds, and some grasshoppers are used to vary the diet.

The first reach Oberlin about March 20th, and the last return south about the middle of October.

63. (196.) Herodias egretta (Gmel.). 186. American Egret.

Synonyms: Herodias alba egretta, Ardea egretta.

Great White Egret, Great White Heron, White Crane.

Kirtland, Ohio Geol. Surv., 1838, 165, 185.

Dr. Wheaton wrote of this heron, "Rather common visitor in July, August, and September." It is now not only not common, but any record is counted worthy of special mention. Specimens have been taken in Erie, Lora:n, Cuyahoga, and Ashtabula counties in recent years, besides the numerous records from counties farther south. Di. Whea- 
ton knew of no breeding records, but spoke of seeing young birds. His statements seem to indicate that he regarded the occurrence of this heron in Ohio as the result of a northward migration after the breeding season. I have been unable to find any actual breeding records. One of the two Lorain county specimens, taken by Mr. R. E. Jump, near Oberlin, was found during the spring. The majority of occurrences seem to fall in July and August.

\section{4. (19\%.) Egretta candidissima (Gmel.). $18 \%$. Snowy Heron.}

Synonyms: Garzetta candidissima, Ardea candidissima.

Little White Egret.

Wheaton, Ohio Agri. Report, 1860, 368, 377.

The occurrence of this heron in the state nearly duplicates that just given for the American Egret. While every record is regarded as practically accidental for that county in which the record falls, it is significant that the records cover practically all of the state except the extreme northwestern and extreme southeastern parts. On the lake shore, Erie, Lorain, Lake, Ashtabula ; inland, Licking, Hardin, Defiance; and Hamilton on the southwestern border are certainly representative of the whole state. With our present knowledge of this bird we must regard it as rare and irregular as a summer visitor.

65. (200.) Florida cerulea (Linn.). Little Blue Heron.

Synonym: Ardea cærulea.

Entered as hypothetical by Wheaton, Reprint, Ohio Agri. Report, 1861, 21, and also in his 1882 Catalogue. Also as hypothetical by Langdon, Cat. Birds of Cin., 1877, 15. The first published record of this species as unquestionablv a bird of Ohio is as follows:

McCormick, L. M., Auk, X, Oct., 1892, 397. Record of a bird captured near Oberlin by Mr. R. E. Jump, about 1882.

The distribution of this little heron in Ohio is hardly less irregular than that of the two egrets. Since the publication of the Lorain county specimen others have been taken in 
Hamilton (Dury and C. C. Smith), Morgan (Morris and Arrick), where it was found breeding, Ashtabula (Sim), Perry (DeLong), Pike (Henninger). Reports from Columbiana and Defiance clearly refer to the Green Heron. The movements of this heron are too erratic to make predictions of its probable occurrence worth while.

\section{6. (201.) Butorides virescens (Linn.). 188. Green Heron.}

\section{Synonyms: Ardea virescens.}

Fly-up-the-creek, Shytepoke.

Kirtland, Ohio Geol. Surv., 1838, 165.

This is the common and well-known heron in Ohio. It is common and breeds everywhere in the state where there is water enough to furnish food and trees or other cover enough to hide the nest and young. In Lorain county it frequently nests in orchards bordering swamps, or in the thick second growth on a hillside.

The Green Heron consumes quantities of grasshoppers, and probably other large insects, besides its diet of tadpoles and water insects, and small batrachians. It is too useful to be persecuted for its ungainly carriage.

The first reach the state during the last week in April, usually, and the most have gone south by the first of October, but individuals may tarry even after the middle of November where the fishing is good.

6\%. (202.) Nycticorax nycticorax navius. (Bodd.). 189.

Black-crowned Night Heron.

Synonyms: Nyctiardea grisea var. nævia, Ardea discors, Nyctiardea gardneri, Ardea nævia.

Night Heron, Quawk, Squawk, Qua-bird, American Night Heron, Night Raven.

Kirtland, Ohio Geol. Surv., 1838, 165, 184.

This heron is locally common in the state, but seems to be absent from many regions. It is a summer resident wherever it is found. Its semi-nocturnal habits probably 
account for its apparent absence from many places where it should breed.' It is another of the swamp loving hirds, nesting in the trees and bushes which grow in the swamps or in wet places.

Migration dates are lacking. It is likely that it winters in some favorable places in the state. Observers should be on the lookout for it.

Order PALUDICOLÆ. Cranes, Rails, Coots, Gallinules.

Suborder GRUES. Cranes.

Family Gruide. Cranes.

All three of the North American cranes have been found in Ohio, one of them having wandered from the west. In general appearance the cranes show a marked resemblance to the herons, but the space in front of the eye is covered with bristles instead of being bare. While migrating they fly in long files. They are not such strict marsh haunters as the herons, but frequent uplands also. They are omnivorous feeders, often swallowing indigestible matter and disgorging it after a time. Frogs, lizards, snakes, field-mice and probably insects, and vegetable food are eaten with equal relish apparently.

68. (204.) Grus americana (Linn.). 238.

Whooping Crane.

Synonyms: Ardea americana.

White Crane.

Kirtland, Ohio Geol. Surv., 1838, 165.

The reports of the occurrence of this bird come from the westerr half of the state, where it appears to be a rare migrant.

I find no dates of migration. Judging from the migrations in Iowa at nearly the same latitude, they should be seen passing northward in a long thin line during the last week in March and the first week in April. 
69. (206.) Grus mexicana (Mül1.). 239.

Sandhill Crane.

Synonyms: Grus canađensis, Arđea canadensis, A. mexicana. Brown Crane, Southern Sandhill Crane, Commion Brown Crane.

Wheaton, Ohio Agri. Report, 1860, 370, 480.

While this crane is by no means common it is rather more rumerous than the preceding species. It has been found breeding at Chicago Junction, and near Toledo. The eggs taken at Chicago Junction were successfully hatched and the young reared and kept in captivity until their natural death. One of the three birds of this lot was preserved by Mr. E. E. Masterman, of New London, and is now in the Oberlin College museum. It is a fine large bird in almost perfect plumage.

The migrations should occur at the same time as those of the Whooping Crane. The cranes may be distinguished - from other birds in flight by the manner of flight. After perhaps ten deliberate wing strokes there is a period of soaring flight of nearly the same duration, then another beating of the wings followed by a soaring, and so on. When the birds settle too close to the ground in this straight-away flight they circle upward by means of the same style of flight as when going straight ahead. At intervals they croak in concert, creating a disturbance that must arrest attention. In flight, legs and neck are stretched out at full length.

Suborder RALLI. Rails, Gallinules, Coots.

Family RaLlide.

In food habits the species comprising this family agree in general. All eat seeds, tender vegetation, worms, insects, crustaceans, mollusks, and with these some rubbish. The rails and gallinules live in the swamp vegetation very largely while the coots live and feed more in the open water and are therefore more often seen. The rails are averse to leaving the cover of the grass, and will do so only when suddenly 
disturbed. They are so protectively colored, and know so well how to assume protective attitudes, that they have small need to leave their covers.

70. (208.) Rallus elegans Aud: 231. King Rail.

Synonyms: Fresh-water Marsh Hen, Red-breasted Rall. Wheaton, Ohio Agri. Report, 1860, 369, 378.

Inland this does not appear to be a common bird, but in shallow ponds or lagoons near the lake it is common. It is probably a summer resident wherever it occurs in the state, nesting in the marshes.

It reaches Oberlin about the first of May, but I have no records for the southward migration.

71. (212.) Rallus virginianus Linn. 232.

Virginia Rail.

Nuttall, Man. II, 1835, 205.

This is probably the most common of the rails along the lake front where it is found in every marsh of any extent, and may even resort to wet meadows to nest. $\mathrm{He}$ is so sly and so hard to flush in spring that few but those who are on the lookout and know where to find him realize his presence. The nest is generally placed on a hummock formed by the roots of a bush or tuft of grass in the marsh, often without concealment. In movement this bird resembles a chicken, just as the King Rail resembles a hen. It is less common than the Sora away from the lake marshes, becoming even rare as a summer resident near our southern border.

The Virginia Rail reaches Lorain county about the first of May, and has gone south by the middle of September.

72. (214.) Porzana carolina (Linn.). 233. Sora.

Synonyms: Rallus carolinus.

Carolina Rail, Ortolan, Crake, Carolina Crake, Common Rail.

Kirtland, Ohio Geol. Surv., 1838, 165, 185. 
The Sora is a fairly common inhabitant of the marshes and wet meadows wherever they occur in the state. It appears to be a little less numerous south than north. It frequently nests in wet meadows or in the tall grass bordering ditches. During the migrations it not infrequently strikes buildings or wires or other obstructions, and is either killed or hurt or dazed and is brought to notice more frequently than any of the other rails in this way. One that had been injured in the breast was found in the court of Peters Hall, Oberlin, when the building was opened in the morning. There had been no open doors or windows, nor any broken window where it might have entered. Its appearance there could not be accounted for unless it had squeezed under a door in the basement.

The Sora reaches Oberlin shortly after the first of May, according to my records. It probably arrives earlier but is unnoticed at first. I have no records of its departure southward, but since the date of capture of the one mentioned above was October 23, 1896, it seems likely that the departure is not far from that date.

73. (215.) Porzana noveboracensis (Gmel.). 234. Yellow Rail.

Synonyms: Rallus noveboracensis, Fulica noveboracensis.

Yellow-breasted Rail, Upland Rail, Yellow Crake, Little Yellow Rail.

Kirtland, Ohio Geol. Surv., 1838, 165, 185.

This little rail is reported as rare in the six *counties where it has been found. There is good reason to believe that it is much more numerous than the records show, because it is both so small and so hard to flush from its reedy retreats that we almost never see it. Systematic search should reveal it in many localities where it has never been seen.

I can find no records of nests actually found within the state, but the dates upon which many specimens have been found clearly indicate that this rail breeds in the northern part of the state at least.

*Ashtabula, Cuyahoga, Erie, Hamilton, Lorain, Portage. 
74. (216.) Porzana Jamaicensis (Gmel.). Black Rail.

Synonyms: Rallus jamaicensis.

Little Black Rail, Little Black Crake.

Entered as hypothetical by Dr. Wheaton in his 1882 Catalogue on the authority of Dr. Langdon, whose record was also hypothetical. The first published record must therefore stand as follows:

Dury, Charles, Journal Cin. Soc. Nat. Hist., 13, July, 1890, 97.

This specimen, one of two seen, was captured near Carthage, May 17, 1890, at Ross Lake. I find no other authentic record.

\section{5. (218.) IONORnis Martinica (Linn.). 235. Purple Gallinule.}

Synonyms: Porphyrio martinica, Gallinula martinica, Fulica martinica.

Wheaton, Ohio Agri. Report, 1860, 369, 378, hypothetical. The first unquestioned record seems to be as follows:

Wheaton, Bull. Nut. Orn. Club, II, 1877, 83. Specimen captured by Dr. Howard E. Jones, at Circleville, May 10, 1877.

The first specimen captured in the state of which we have any record seems to be that reported to Dr. Wheaton. "Dr. Hunt informs me of the capture of this species near the mouth of the Big Miami river, on March 31, 187\%." "Two specimens $* * * *$ have since been taken at Madisonville, one by the writer in the latter part of April, and another by Mr. William H. Whetsel, early in May. Mr. John W. Shorten also reports one killed May 1, at Jones' Station (about thirty miles from Cincinnati), by J. H. Kelly, Esq." (Wheaton.)

Prof. E. L. Moseley reports a specimen captured at Sandusky bay, April 28, 1896 ; Dr. Carl Tuttle, one which had flown against the telegraph wires and was killed, "along the lake shore," September 2, 1894 (Auk XII, 191).

No other records than these have come to my knowledge. 


\section{6. (219.) Gallinula galeata (Linn.). 236. Florida Gallinule.}

Synonyms: Gallinula chloropus, Crex galeata.

Common Gallinule, Red-billed Mud-hen.

Kirtland, Ohio Geol. Surv., 1838, 165, 185.

This rather conspicuous swamp bird is fairly common over the entire state where there are marshes large enough to accommodate it. In many of the larger swamps it is almost abundant. At Licking reservoir we found it in considerable numbers. At the Sandusky bay marshes it is more than common. I have not found it at the small swamps at Oak Point. A few were to be found at Lorain before the ship yards were established there. It does not flush readily from its retreats, but makes such a disturbance when running through the reeds and grasses that it can readily be traced by sound. In the vicinity of the young it is possible to approach within studying distance of the parents.

They first reach northern Ohio about the first of May, and the last is seen about the middle of September.

\section{7\%. (221.) Fulica americana Gmel. $23 \%$ American Coot.}

Synonyms: Coot, Mud-hen, Crow Duck, White-billed Mud-hen. Wheaton, Ohio Agri. Report, 1860, 369.

While the Coot is more often seen than the Florida Gallinule by the casual bird student, it is not as numerous in individuals in the state. It generally visits the Oberlin water-works reservoir during both migrations, and may visit the open water and ponds in the vicinity of the lake shore at such times. If it remains all winter in the southern counties it does so rarely. It was not found breeding at either the Licking or Lewiston reservoirs, nor at Chippewa lake, but one bird was seen by me at the Sandusky bay swamps in July. It appears to breed sparingly in our most northern marshes, but is not generally common in summer.

The Coot enters the state late in March, reaches the lake 
shore soon after the first of April, and returns south again during late October.

\section{Order LIMICOLÆ. Shore Birds.}

The Shore Birds very largely subsist on such animal food as may be found in the soft mud or along the borders of streams and ponds or on the shore of lake or ocean. All species found in Ohio except the Plovers probe the mud for the worms, insects and their larvæ, mollusks and other small animals found there, but the Plovers glean mostly from the surface and may also take some vegetable matter. They are decidedly useful birds, keeping in check insects which other birds would not destroy.

Family Phalaropodide. Phalaropes.

Two of the three species of this family are found in Ohio, and the other one may yet be discovered. At best they are unusual and wary, wading in the water and swimming on its surface with ease.

\section{8. (223.) Phalaropus lobatus (Linn.). $22 \%$. Northern Phalarope.}

Synonyms: Lobipes hyperboreus, Phalaropus hyperboreus, Tringa lobata.

Red-necked Phalarope.

Kirtland, Am. Journal Sci. and Arts, XL, 1841, 21.

I have been unable to add any records of this species to those given by Dr. Wheaton, which are as follows: A single specimen (not a pair) taken near the pier in Cleveland harbor in November, 1840 (?), and preserved in Dr. Kirtland's collection. A pair taken by Dr. Jasper, on the Scioto river, also in winter plumage, one of them preserved in Dr. Wheaton's, the other in Oliver Davies' collection. Dr. Wheaton also remarks that others have been taken by $\mathrm{Mr}$. R. K. Winslow and others on the lake shore. The stattus of the species as an Ohio bird must rest upon the three captured specimens. 
79. (224.) Steganopus tricolor Vieill. 228. Wilson Phalarope.

Synonyms: Steganopus wilsoni, Phalaropus wilsonii, Phalaropus tricolor.

Kirtland, Ohio Geol. Surv., 1838, 165, 185.

This phalarope is reported only from Erie county where it is stated it may breed. It has been found in Lorain county three times, each time during the first week in May. While it may breed in the north-western part of the state there is no record of its doing so.

The few notes upon its migration seem to indicate that it reaches the northern counties-soon after the first of May. A more careful search for this interesting bird should discover it in many places where it is not known at present. It is wary and difficult to approach.

Family Recurvirostride. Avocets and Stilts.

Both North American members of this family have been found in the state. They are also rare, and, like the last family, are waders. They do not swim as well, since their toes lack the lobes on their sides.

80. (225.) Recurvirostra americana Gmel. 229. American Avocet.

Kirtland, Ohio Geol. Surv., 1837, 166185.

The rarity of this species in the state is attested by the paucity of reports of its occurrence. Dr. Wheaton placed it upon his list on the authority of Dr. Kirtland, who reported specimens that had been killed near Cincinnati by sportsmen. Mr. Charles Dury makes this later record, "Has been seen on sandbar of Ohio river." Mr. A. Hall "saw a specimen taken near Cleveland." Rev. W. L. Dawson informs me of a specimen secured at St. Mary's reservoir, Nov. 10,1882 , by Mr. Clemens Utter, which is now in the collection of the State University. Mr. R. W. Smith reports "One specimen, in winter plumage, taken at Lebanon 
reservoir, in the spring of 1880, and now in Mr. Gould's collection."

This exhausts what we know of the Avocet as an Ohio bird.

\section{1. (226.) Himantopus mexicanus (Mull.). 230. Black-necked Stilt.}

Synonyms: Himantopus nigricollis, Charadrius mexicanus.

Stilt, Long-shanks, Lawyer.

Langdon, Journal Cin. Soc. Nat. Hist., I, 1879, 182.

The above citation rests upon the authority of Mr. Dury. Dr. Wheaton also states that "The Stilt has been repeatedly taken on Lake Erie, as I am informed by Mr. Winslow." There are no more recent records.

Family Scolopacide. Snipes, Sandpipers, etc.

Ohio is credited with twenty-seven members of this varied family. The Woodcock is strictly sylvan, found nowhere but in the wet woods. Many are shore haunters, some feed in wet meadows, and most of them are likely to. be found in or around the field ponds and spring flooded places where the water stands for a few days or weeks. All have sensitive bills with which they are able to feel the worm or insect in the mud, and some are able to move the tip of the bill without moving the rest of the bill. Some travel in flocks of varying size while some are solitary. Reference to the individual species will discover other points which it would not be possible to treat here.

82. (228.) Philohela minor (Gmel.). 200. American Woodcock.

Synonyms: Scolopax minor.

Bog-sucker, Big Mud Snipe, Big-headed Snipe, Blind Snipe, Whistling Snipe, Timber Doodle, Bog Bird, Night Partridge, Night Peck, Hookum Pake, "Pewee," Labarador Twister, Whistler.

Kirtland, Ohio Geol. Surv., 1838, 165.

The Woodcock is too much saught after and therefore 
too well known as a game bird to pass unnoticed in any locality. It is generally reported as being a fairly common breeding bird throughout the state. Naturally it is more numerous in wet or damp woods than elsewhere, and may become even abundant in restricted localities which afford it both cover and abundant food. Being semi-nocturnal, it must be flushed to be seen during the day. At twilight one may be favored with the so-called song and peculiar mazy dancing flight during the mating season, in regions where the birds are numerous.

Woodcock is the only woods-haunting bird which probes deep into the mud for the worms and-insect larvæ which lurk there. It therefore performs an office as an insect destroyer which is shared by no other bird. As its name implies, it is strictly sylvan, seldom venturing out of the brushy retreats except to pass from woods to woods, or during the mating flight.

One would naturally expect a bird which depended upon mud-inhabiting insects for food to tarry south until warm weather insured an abundant supply of its food; but the Woodcock reaches Oberlin during the last week in March at the latest, often by the middle of that month, and does not return south until early November.

\section{3. (230.) Gallinago delicata (Ord). 201. Wilson Snipe.}

Synonyms: Gallinago wilsoni, G. media wilsoni, Scolopax wilsonii, S. delicata.

American Snipe, Jack Snipe.

Kirtland, Ohio Geol. Surv., 1838, 165.

The Jack Snipe is still an abundant migrant in some localities, but is becoming scarce in others. It is the mud prober of the fields and treeless bottom lands, complementing the work of the Woodcock. There can be no doubt that this snipe does good service for the farmer in ridding his wet fields of the insect larvæ which burrow there ready for the young crop soon to appear. It is a pity that the erratic flight of the snipe offers so many temptations to the sportsman, 
and his flesh to the epicure. He is a necessary factor in the economy of agricultural science.

Reports of the breeding of this species in several counties pretty clearly indicate mistaken identification of the bird. So far as I have been able to judge, there are still no authentic records of nests or young actually found in the state. It may yet be found breeding in the north-western counties, and possibly elsewhere.

There is unmistakable evidence that this snipe sometimes winters in the state. Prof. E. L. Moseley records them in winter some miles west of Sandusky where springs prevent the freezing of the mud and water. In the southern counties there are January records which can hardly be migrating birds.

The first migrants reach Oberlin about the first of April, and some remain well into May. Their return in autumn is too irregular to make any definite statements possible, except that the last tarry well toward the end of October.

84. (231.) Macrorhampinus griseus (Gmel.). 202. Dowitcher.

Synonyms: Scolopax grisea.

Red-breasted Snipe, Gray Snipe, Gray-back, Gray-backed Snipe, Long-billed Dowitcher, Brown-back. Kirtland, Ohio Geol. Surv., 1838, 165.

Judging from the reports, it is a decidedly rare bird in Ohio. Dr. Langdon and Mr. Dury report it without comment as rare near Cincinnati, and Prof. Moseley reports it rare without comment at Sandusky. It is not mentioned by others. It has never been taken in Lorain county.

It should be looked for in April and May, and again in late July, in August and probably in September.

85. (232.) Macrorhamphus scolopaceus (Say.). 202a. Long-billed Dowitcher.

Synonyms: Macrorhamphus griseus scolopaceus, Limosa scolpacea.

Western Dowitcher, Red-bellied Snipe, Greater Long-neck. Wheaton, Ohio Agri. Report, 1884, 1875, 572. 
There seemed to be considerable confusion in Dr. Wheaton's mind regarding the two Dowitchers, since this species was not included in the body of his catalogue, but was given a place in his check-list. It seems likely that his $M$. griseus covered this species which was then regarded as a subspecies. I have but two specific references to this species, both from Cincinnati. Mr. William Hubbell Fisher has permitted me to examine a specimen in his private collection, and Mr. Charles Dury reports it as rare. If there be other specimens in collections they have not been brought to my notice. Its normal range would seem to lie west of Ohio, although the other species is the rarer in Indiana, according to Butler.

86. (233.) Micropalama himantopus (Bonap.). 203. Stilt Sandpiper.

Synonyms: Tringa himantopus.

Wheaton, Ohio Agri. Report, 1874, 1875, 572.

Dr. Wheaton admits it to his catalogue on the authority of Mr. Winslow. Mr. A. Hall enters it as "Very rare," near Cleveland. The only other record is the following: Forest and Stream, XXXIII, No. 1816, p. 265 (?). Dr. E. Sterling. 1889.

87. (234.) Tringa canutus Linn. 204. Knot.

Synonyms: Red-breasted Sandpiper, Gray-back, Robin Snipe, May Bird, Ash-colored Sandpiper, White-bellied Snipe, Silver-back, Red-breast Plover,' Beach Robin, Horse-foot Snipe, Robin-breast, White Robin Snipe, Red Sandpiper, Blue Plover.

Wheaton, Ohio Agri. Report, 1860, 380, hypothetical. The first published record of a specimen actually taken seems to be the following:

Wheaton, Ohio Geol. Surv., 1882, Vol. IV, Pt. 1, 478.

"Mr. Ed. Savage, of this city, captured a fine male, of a pair in full breeding plumage, at the Licking reservoir, May 2\%, 1878." 
Prof. E. L. Moseley, of Sandusky, is the only contributor to report it.

88. (235.) ArQuatella maritima (Brünn.). 205. Purple Sandpiper.

Synonyms: Tringa maritima.

Wheaton, Ohio Agri. Report, 1860, 380, hypothetical.

Apparently the only specimen actually captured in the state is that reported by Mr. Winslow from near Cleveland, which he says was preserved in the collection of the Cleveland Academy of Sciences.

89. (239.) Aсtodromas maculata (Vieill:). 206. Pectoral Sandpiper.

Synonyms: Tringa maculata.

Grass Snipe, "Jack Snipe," Krieker.

Wheaton, Ohio Agri. Report, 1860, 369.

This distinctively field sandpiper is fairly common as a migrant in all parts of the state. It may be abundant at some times during the migrations. It travels in flocks of from half a dozen to fifty or more birds which move as one bird. In general habits these birds resemble the plovers more than the sandpipers, apparently gleaning as well as probing for food. They must be classed as true benefactors to the farmer.

The first migrants reach Oberlin about the middle of April, and some tarry into the first week of May. The first return late in July and some remain about the wet bottomlands until the first of October.

\section{0. (240.) Actodromas fuscicollis (Vieill.). $20 \%$. White-rumped Sandpiper.}

Synonyms: Actodromas bonapartii. Tringa bonapartii. Tringa fuscicollis.

Bonaparte's Sandpiper.

Wheaton, Ohio Agri. Report, 1860, 369.

In spite of the statement by Dr. Wheaton that this sandpiper is a "not uncommon spring and fall migrant on Lake 
Erie, rare in the interior of the state," there remain only the records mentioned by him in his 1882 catalogue. Dr. Wheaton found it once, "in a locality known as the 'Broomcorn' fields, near Shadeville in Franklin county, late in October, 1875." Dr. Langdon's record follows: "Two specimens, the first recorded for this vicinity, taken September 6, 1879, near Glendale, Ohio, by Mr. J. B. Porter; both were males." The records of Mr. R. K. Winslow must be discounted, in the absence of specimens.

Bird students should be on the lookout for this species, which should be found in some numbers in the state.

\section{1. (241.) - Actodromas bairdir Coues. 208. Baird Sandpiper.}

Synonyms: Tringa bairdii.

Wheaton, Ohio Agri. Report, 1874, 572.

While this sandpiper is reported by Mr. Dury alone of all those who have handed lists to me, it cannot be as rare as that would indicate. It has been taken in Lorain county several times during its southward migration, but never in spring that I am aware of. It should be found in some numbers with the other sandpipers. Probably the whole trouble is that none know the bird in the field. The winter plumage is not as distinctive as one could wish, but identification is not difficult.

92. (242. Aсtodramas minutilla (Vieill.). 209. Least Sandpiper.

Synonyms: Tringa minutilla, T. wilsonii. Kirtland, Ohio Geol. Surv., 1838, 165.

The Least Sandpiper usually reaches Oberlin in flocks after May 10. It is easily approached and readily identified, yet few seem to know it. I have always found it along the borders of ponds probing in the mud, or bathing in the water's edge. It was found in considerable numbers by $\mathrm{Mr}$. Dawson and myself on Middle Bass Island during the first week in August, 1901. I have not seen it in the southward migration in Lorain county. 
93.

(243a.) Pelidna alpina pacifica (Cous). 210. Red-backed Sandpiper.

Synonyms: Tringa alpina var. americana, Pelidna alpina americana, P. pacifica, Tringa schinzii.

American Dunlin, Black-breast, Black-bellied Sandpiper, Ox Bird.

Kirtland, Ohio Geol. Surv., 1838, 165, 185.

There has apparently been a considerable decrease in the numbers of this species since Dr. Wheaton prepared his catalogue. It is nowhere given as common in the state. It is rare in Lorain county at any time of year, but has been recorded more often in the autumn than during the spring migrations. It is strictly a migrant across the state.

Migration dates are too few to be of service in determining the time of migration, but they indicate a northward movement during late April or early May, continuing well toward the close of May; and a return late in September or early October.

\section{4. (246.) Ereunetes pusillus (Linn.). 211. Semipalmated Sandpiper.}

Synonyms: Ereunetes petrificatus, Tringa pusilla. Peep.

Wheaton, Ohio Agri. Report, 1860, 369.

This and the Least Sandpiper might easily be confused by any one not familiar with the two species. The difference in size would hardly be apparent unless the birds were sear together. It is reported generally as not common during the migrations, but may be in some localities during favorable seasons. They often mingle with the Least Sandpipers in the fall at the common feeding-grounds of the shore birds. Both species, with many others, were recorded at the lagoon on Middle Bass Island during the first week of August, 1901, by Mr. Dawson and myself.

They appear to migrate somewhat earlier than the Least Sandpipers, in spring, but may return with them. 
95. (248.) Calidris arenaria (Linn.). 212. Sanderling.

Synonyms: Tringa arenaria.

Ruddy Plover, Beach-bird.

Wheaton, Ohio Agri. Report, 1860, 480.

This light colored sandpiper is often common along the lake shore during both migrations. It appears to be less common in the interior of the state, but should be found on the gravelly beach of lake or large pond or reservoir. In flight the flocks are compact and move as one bird. I saw eleven killed from a flock of less than thirty birds with one discharge of the shot-gun. I have never seen the birds except in flocks of from six to fifty individuals.

The food consists largely of the insects washed ashore by the waves. and any other fragments of animal matter whin the birds care for. They seldom run out on the beach far irom the water, but depend largely upon the waves for food.

It passes through Lorain county during May, rarely tarrying into the first week of June, and returns by the middle of August, remaining well toward October.

\section{6. (249.) Limosa fedoA (Linn.). 213. Marbled Godwit.}

Synonyms: Limosa fœda, Scolopax fedoa.

Great Marbled Godwit, Doe Bird, Dough Bird, Marlin. Kirtland, Ohio Geol. Surv., 1838, 165, 185.

I am able to add nothing to Dr. Wheaton's records of this bird in the state. "Dr. Kirtland notes its capture in several instances in northern Ohio. Mr. Langdon states on the authority of Mr. Dury, that thirty-three were 'shot in one day, near the mouth of the Little Miami, some years ago, by Charles Weeks, Esq.' A specimen was taken by a son of Dr. Jasper in the immediate vicinity of this city (Columbus), April 21, 1879." The wariness of the shore birds and the absolute necessity of securing specimens of most of them to make the identifications sure, are reasons which make the records of so many so unsatisfactory. 
97. (251.) Limosa hemastica (Linn.). 214. Hudsonian Godwit.

Synonyms: Scolopax hæmastica.

Smaller Doe-bird, American Black-tailed Godwit, Ring-tailed Marlin.

Kirtland, Ohio, Geol. Surv., 1838, 165, 185.

The records which Dr. Wheaton gives for this species are all that I have been able to find. "Dr. Kirtland notes its capture in the vicinity of Cincinnati, and $\mathrm{Mr}$. Winslow mentions its occurrence near Cleveland. I met a flock of eight birds, in the spring of 1858 , wading in a shallow pond in an old brickyard within the city (Columbus) limits, but was not so fortunate as to secure specimens. In the spring of 1861 a fine specimen was taken below the State dam, near the city, by a sportsman and taxidermist, which was preserved until recently." There appear to have been but two specimens actually captured in the state. We should make a better record than this for Ohio.

98. (254.) Totanus melanoleucus (Gmel.). 215.

$$
\text { Greater Yellow-legs. }
$$

Snyonyms: Scolopax melanoleuca, Gambetta melanoleuca, Totanus vociferus.

Greater Tell-tale, Greater Yellow-shanks, Long-legged Tattler, Stone-snipe.

Kirtland, Ohio Geol. Surv., 1838, 165.

Fairly common during the migrations over the entire state. It may be absent from some restricted localities where there are no ponds or wet meadows to furnish feeding places. Both Yellow-legs feed standing "knee" deep in the water, often immersing the entire head, but oftener darting about and thrusting here and there for some fleeing insect or tadpole. While they are not distinctly beneficial they are certainly not harmful to agricultural interests. They may often be seen in small flocks of about a dozen or less individuals, or singly on the borders of ponds of almost any extent, or on the lake shore. 
This species reaches Oberlin about April 20th, and often tarries well into May. It returns again about the middle of September and remains a month. Rev. W. F. Henninger has a record for March 14, 1899, which is certainly early for the species, for southern Ohio.

\section{9. (255.) Totanus flavipes (Gmel.). 216. Yellow-legs.}

Synonyms: Scolopax flavipes, Gambetta flavipes.

Lesser Tell-tale, Common Yellow-legs, Lesser Yellow-shanks. Kirtland, Ohio Geol. Surv., 1838, 161.

Judging from my own experience, this is the commoner form of this genus in northern Ohio at least. It is found in the same situations as the larger species, and frequently associates with it, while feeding, but seems to prefer to fly only with its own kind. I have seen companies of fifteen to twenty birds, in the ratio of two of the Greater to three of the Lesser Yellow-legs, feeding together, in starting up from the pool immediately separate, each species flying by itself.

Rev. W. F. Henninger has a record for southern Ohio on March 18, 1901. This is undoubtedly the earliest record for the appearance of this species for the state. The average date of arrival at Oberlin falls close to the first of May. This may be too late, since there are records for the middle of April. The southward movement begins early in August and continues to the end of September.

\section{0. (256.) Helodromas solitarius (Wils.). $21 \%$. Solitary Sandpiper.}

Synonyms: Totanus solitarius, T. chlorypigius. Rhyacophilus solitarius, Tringa solitaria.

American Green Sandpiper, Solitary Tattler, Wagtail, Tip-up. Kirtland, Ohio Geol. Surv., 1838, 165.

As its name implies, this bird is solitary in its habits, and does not occur in flocks. It clearly prefers a small pond in the borders of some open woods, or in the midst of a pasture in which there remain scattering trees. It may also be 
found in more open situations during the migration period, rarely loosely associated with Yellow-legs. I have never seen it in merely damp places, but it sometimes frequents small temporary streams which run through meadows. There seems good evidence that this sandpiper breeds sparingly from the vicinity of Columbus northward. I have seen individuals in each summer month. Dr. Wheaton found a young bird in the care of its parents near Columbus. The ease with which this species may be confounded with the Spotted Sandpiper may account for its apparent absence during the summer. It has the general appearance, and a note which closely resembles that of the Spotted Sandpiper, but lacks the round spots on the underparts, and has white spots on its back. The white spotted back should positively separate it from the Spotted Sandpiper, and its note should be equally distinctive from the Yellow-legs which also has white dorsal spots.

This sandpiper reaches Oberlin during the third week of April, and returns south rather late in October.

\section{1. (258.) Symphemia Semipalamata (Gmel.). 218. Willet.}

Synonyms: Totanus semipalmatus, Scolopax semipalmata.

Semipalmated Tattler.

Kirtland, Ohio Geol, Surv., 1838, 165.

Besides Dr. Wheaton's records, Dr. Langdon and Mr. Dury are the only ones who report this species. It has not been taken in Lorain county. Dr. Wheaton's statement, clearly based upon Dr. Kirtland's information, that it is "Not a common spring and fall migrant, probably breeds in northern Ohio," indicates that since 1838, when Dr. Kirtland found it in summer on the lake shore, it has become not only rare but almost extinct. If it still occurs near Cincinnati it is very rarely. Observers should watch carefully for the birds and report any occurrences. 
102. (261.) Bartramia longicauda (Bechst.). 220. Bartramian Sandpiper.

Synonyms: Actiturus bartramius, Totanus bartramius, Tringa bartramia, Tringa longicauda.

Upland Plover, Bartram's Tattler, Field Plover, Grass Plover, Prairie Pigeon, Prairie Snipe.

Audubon, Orn. Biog., IV, 1838, 24.

This large upland sandpiper is fairly common during the entire summer over the greater part of the state, being rather less common along our southern border as a summer resident. While a few breed in the vicinity of Oberlin each year, the individuals are so few that they might easily be counted and their breeding places located. These birds are rather gleaners than probers, and therefore feed upon the insect life at the surface of the ground and among the grass, doing good service in meadows.

The average appearance for Oberlin is April 15, and the average date of last seen October 15. Rev. W. F. Henninger has a record for March 21, 1902, for southern Ohio. The birds leave the state about October 25.

103. (262.) Tryngites subruficollis (Vieill.). 221. Buff-breasted Sandpiper.

Synonyms: Tryngites rufescens, Tringa subruficollis, T. rufescens.

Kirtland, Ohio Geol. Surv., 1838, 165.

"Rare migrant, only noted in the fall. In addition to its occurrence noted by Dr. Kirtland (Cleveland, two specimens captured in August, 1840), it has since been taken on several occasions near Cleveland. A specimen was taken in the immediate vicinity of this city, August $31,18 \% 6$, which is now in the collection of the Ohio State University. This bird was in company with Semipalmated Plover and Semipalmated Sandpipers, on a gravelly bank of the Scioto river." (Wheaton, 1882.) Nothing more has been reported concerning this species. 
104. (263.) Actitis macularia (Linn.). 222.

Spotted Sandpiper.

Synonyms: Tringoides macularius, Totanus macularius, Tringa macularia.

Sandpiper, Spotted Tattler, Peet-weet Wag-tail, Tip-up,

Teeter-tail, Sand-lark.

Kirtland, Ohio Geol. Surv., 1838, 165.

This is the common little sandpiper throughout the state. No one who has walked by a lake shore or along the margins of any considerable stream or moderate to large pond, can have failed to see this bird. It is common everywhere all summer, breeding in fields or on the steep banks of lakes and rivers. Only once have I failed to find it on the lake shore in summer, gleaning among the debris thrown up by the waves. I have also watched it gleaning in the meadows and plowed fields.

The first reach Oberlin about April 1\%th, and the last are seen during the first week of September. These dates do not vary materially from those for southern Ohio contributed by Rev. Mr. Henninger.

\section{5. (264.) Numenius longirostris Wils. 223. Long-billed Curlew.}

Synonyms: Sickle-bill.

Kirtland, Ohio Ohio Geol. Surv., 1838, 165, 185.

The reports indicate that this rather conspicuous bird is rarely seen within the state, but the places of occurrence are so well scattered that it may be expected to occur occasionally over practically the whole of the state except the southeastern fifth. Dr. Wheaton records specimens taken near Cleveland by Dr. Kirtland; at Licking reservoir, specimens captured there having been examined by Dr. Wheaton, and the probability of its occurrence at St. Mary's reservoir; and Dr. Langdon's records of several specimens taken near Cincinnati. To these may be added Defiance (Slocum), Erie (Moseley), and an additional record of a flock of seven at Licking reservoir, May 31, 1902, recorded by the writer and Mr. Irving A. Field. While it is possible 
that this species may be found breeding in some parts of the state, no positive record has yet been made to that effect.

It is likely that the birds arrive from the south about the middle of April, tarrying well toward June as the records prove. They might be mistaken for the Bartramian Sandpiper when so far away that the extremely long curved bill cannot be seen, but otherwise they should be easy of identification.

106. (265.) Númenius hudsonicus Lath. 224. Hudsonian Curlew.

Synonyms: Jack Curlew, Short-billed Curlew, American Wim. brel.

Kirtland, Ohio Geol. Surv., 1838, 165, 185.

Dr. Wheaton gives practically the same records for this curlew as for the Long-billed. Records from Defiance (Slocum), Erie (Moseley), and Ashtabula (Sim) have come to me. This species was regarded as less likely to occur than the preceding, by Dr. Wheaton. So far as the reports received are concerned it would appear to be scattered over the state about the same. It is strictly a migrant in the state Dr. Wheaton had never seen it in Ohio.

10\%. (266.) Numenius borealis (Forst.). 225. Eskimo Curlew.

Synonyms: Scolopax borealis.

Esquimaux Curlew, Dough-bird.

Wheaton, Ohio Agri. Report, 1860, 380, 480.

Dr. Wheaton's statement that it is a "Not common spring and fall migrant" seems to be pretty largely based upon a report from Mr. R. K. Winslow that "it is not rare in the vicinity of Cleveland," without specimens to prove the statement. Dr. Wheaton records only the capture of a specimen taken near Cincinnati by Mr. Shorten, in September, 1878 , but states that he saw a single bird in a flock of Golden Plovers in the vicinity of Columbus. Prof. E. L. Moseley reports it as rare in Erie county as seen by Dr. Graffe. The similarity of this and the last species makes 
any records other than those of actual captures of questionable value. Fortunately we have a specimen taken within the state.

\section{Family Charadridis. Plovers.}

The Plovers have short beaks which are not fitted for probing in the mud, but for gleaning from the surface. They wade some, but seem to prefer to keep near the edge of the water. They have a strong tendency to flock, but may also be found singly, even during the migrations.

108.

(270.) Squatarola squatarola (Linn.). 195. Black-bellied Plover.

Synonyms: Squatarola helvetica, Charadrius helveticus, C. squatarola, Tringa squatarola, T. helvetica.

Swiss Plover, Bull-head Plover, Whistling Field Plover, Oxeye, Beetle-head.

Kirtland, Ohio Geol. Surv., 1838, 165, 185.

This plover appears to be rare throughout the stat:. It has not been generally reported, but such reports as have been made indicate that it may be found occasionally everywhere except in the south-eastern fifth. Its migrations begin about the middle of April and may continue well toward June. In the autumn they should be found in August and September.

10.9. (272..) Charadrius dominicus Müll. 196. American Golden Plover.

Synonyms: Charadrius fulvus var. virginicus, C. pluvialis, C. virginicus, C. fulvus.

Golden Plover, Field Plover, Bull-head Plover, Bull-head, Green-back, Green Plover.

Kirtland, Ohio Geol. Surv., 1838, 165, 184.

From common or even abundant during the spring migrations up to the time Dr. Wheaton's work closed, this plover has become hardly more than casual in most sections of the state. It is still found in some numbers occasionally, in spring, in regions where the small lakes are numęrous, and 
1. 'sometimes on the shore of Lake Erie. Several reports to the

: contrary notwithstanding, it does not nest in the state. . Late spring and early autumn records of many of this group of birds do not necessarily indicate that they breed in the region where such records have been made. The "Shore Birds" linger late and return early.

The Golden Plover, as well as several other species, migrates in flocks which fly as one bird. When one individual has been shot from a flock the rest return for the lost one, and may be in danger of a similar fate at the hands of a thoughtless hunter. They should be looked for about the middle of April, and again in late August or early September.

110. (273.) OXyechus vociferus (Linn.). $19 \%$. Killdeer.

Synoryms: Charadrius vociferus. Egialitis vocifera Killdeer Plover, Ring Plover.

Kirtland, Ohio Geol. Surv., 1838, 165.

Of all members of this group of birds the Killdeer is probably the best known, because he talks about himself so much! He is among the first birds to come from the south in early March, not seldom reaching the lake shore with the Robin and Bluebird, but more often about a week behind them. One would expect a bird of his tastes to fare poorly while snow still covers the ground for days at a time, but he seems to find enough to keep him warm and active. At first he stays close to some low, wet place, gleaning from the surface of the mud, or searches out the fields which have been well kept and therefore furnish him with a clear surface to feed upon. It seems likely that the Killdeer sometimes eats soft seeds when insects, worms, and other soft animals are difficult to find, but $I$ have no direct evidence of it. At any rate, he must be classed with the distinctly beneficial birds because of the insect larvæ which he eats.

The first decidedly spring thaw, which may occur late in February or not till the second week in March, brings this bird to Lorain county. He stays all winter in the southern 
part of the state. His stay in the autumn is determined by weather conditions, but he is usually to be found until the first of November, and sometimes well toward the close of that month.

\section{1. (274.) Egiatitis semipalmata Bonáp. 198. Semipalmated Plover.}

Synonyms: Charadrius semipalmatus.

Ring-neck, Ring Plover, Semipalmated Ring Plover. Kirtland, Ohio Geol. Surv., 1838, 168, 184.

This little plover is far more common in autumn than in spring, and Dr. Wheaton records it but once in spring at Columbus-May, 1880. It is not uncommon at the lake shore in autumn, from the last week in July until the middle of September. It often associates with Killdeer and the Sanderlings, but in flight flocks separately. It is generally seen in small flocks, but single individuals are sometimes found on the lake shore as well as on the smaller ponds. Its single black breast band easily distinguishes it from Killdeer if its smaller size does not. I have never seen it feeding except at the water's edge or among the recently thrown-up wash on the shore. Its food seems to be largely insects and small mollusks.

112. (27\%.) Egialitis meloda (Ord). 199. Piping Plover.

Synonyms: Charadrius melodus, Agialitis melodus. Ring-neck.

Kirtland, Am. Journal Sci. and Arts, XL, 1841, 24.

It seems more than likely that the A. O. U. committee will finally reduce this and the next form to one species, but in the absence of legislation it seems necessary to include both forms. The interrupted black breast band of this form and the continuous breast band of the subspecies, a difference upon which the subdivision of the species was largely based, does not seem to be a good character.

Reports of the occurrence of this small plover are meager Dr. Langdon and Mr. Dury report it from Cincinnati, Prof. 
Moseley from Sandusky, there are specimens taken in Lorain county, and the record of Dr. Wheaton for the vicinity of Columbus exhaust the records. It is certainly a rare migrant across the state, probably in late April.

113. (27\%a.) Egialitis meloda circumcincta Ridgw. Belted Piping Plover.

Dr. Wheaton said of this form, in his 1882 catalogue, "Mr. Ridgway describes as a geographical race of this species, var. circumcinctus, from the Missouri region. To this variety Mr. Nelson refers the birds taken in Illinois by him, and doubtless Ohio birds are the same. But specimens of circumcinctus have been taken in various localities on the Atlantic coast and doubtless, as held by Mr. Brewster, the variety is untenable."

There are specimens of both forms in Ohio collections, but circumcincta appears to be the more numerous. Just as we go to press, Mr. W. L. Dawson, Prof. J. S. Hine and the writer have found some half-dozen pairs of this form breeding on the beach of Cedar Point, across from Sandusky, near the new Lake Laboratory of the Ohio State University. A set of four eggs was taken there, in an advanced state of incubation, June 26. This form should be found breeding in any suitable localities over the state.

Family AphrizIDæ. Turnstone.

The species which is found in Ohio always occurs in flocks while it is with us. I have never seen it except on the lake shore, where it was gleaning among the rubbish thrown up by the waves. It is a striking looking bird, easily identified.

114. (283.) Arenaria interpres (Linn.). 194. Turnstone.

Synonyms: Strepsilas interpres, Tringa interpres.

Brant Bird, Calico-black, Bead Bird, Horse-foot Snipe.

Kirtland, Ohio Geol. Surv., 1838, 165, 184. 
The Turnstone appears to be fittle known in the interior of the state. It has been recorded at Cincinnati (Langdon), but not elsewhere away from the lake shore. It is also reported from Erie and Cuyahoga counties. It is somewhat irregular in Lorain county, but generally seen during the spring migrations in small flocks. All of my records fall between May 16 and 20. I have not seen it in autumn. While here it remains near the water's edge, gleaning from the wash of the waves. I have rarely seen it feeding on the loose sand among the larger stones a rod or more from the water. Dr. Wheaton did not find it near Columbus.

\section{ORDER GALLIN压. Gallinaceous Birds.}

To this group belong the Game Birds par excellence. Their flesh is pleasant because they feed so largely upon vegetable matter of various kinds. Careful investigation of the food of these birds reveals the fact that the proportion of cultivated grain eaten is very small, while the weed seeds form a large proportion. There can be no doubt that of the grain eaten much is what has fallen during harvest, and so would be wasted if the birds did not get it. In some localities members of this group do eat grain to a considerable extent, but the habit is not general by any means. In winter buds and tender shoots of trees are eaten, and in summer insects are freely destroyed. There is always great danger that the birds comprising this group will suffer extinction because they are killed both for sport and for their flesh. Legislation limiting their destruction needs to be specific and not disregarded by citizens.

Family Tetraonide Grouse, etc.

115. (289.) Colinus virginianus (Linn.). 184. Bob-white.

Synonyms: Ortyx virginianus, Perdix virginiana, Tetrao virginianus.

Virginia Partridge, "Quail," Partridge.

Wilson, Am. Orn., VI, 1812, 21.

Bob-white is still common in all portions of the state, but 
is evidently less numerous than a score of years ago. It is reported as abundant from a few localities. The prohibitive laws have prevented any great diminution in numbers. It' seems likely that the modern restrictions thrown around the sportsmen will tend to diminish their numbers or at leasst dampen their ardor for the chase, thereby increasing the chances of life for the "Quail." It would be a distinct æsthetic loss if the Bob-white should wholly disappear from our fields and woods. Literature is too full of references to his prophetic warning or encouragement for us to consent to his extinction.

I find no evidence that Bob-white migrates to any appreciable extent: It is probably hardly proof that he does not because a flock or covey is known to occupy the same region the year through, but it looks in that direction. Unfortunately we have almost no means of knowing for a certain-

- ty the individual birds, and so are unable to follow them all the year. It seems likely that there is some small southward movement during the colder weather, or with the appearance of considerable snow.

Dr. Sylvester D. Judd has proved that Bob-white eats very little grain, and that little is probably largely waste grain, but he does consume great quantities of weed seeds, particularly those of the ragweed. Farmers can coax a flock of Bob-whites to their barn-yards by throwing grain out to the flock, but it would be a pity to do so for the purpose of killing them.

116. (300.) Bonasa umbellus (Linn.). 182. Ruffed Grouse.

Synonyms: Tetrao umbellus.

Partridge, Pheasant.

Kirtland, Preliminary Report, Ohio Geol. Surv., 1838, 67.

This strictly woods game bird has rapidly decreased in numbers in the last decade; partly because it has been so persistently hunted and partly because its breeding haunts have been destroyed in so many places. It is reported as still fairly common in the north-eastern third of the state, 
and locally elsewhere, but it is rare in most other localities. None have been seen in Lorain county west of Elyria for three years. Ten years ago it was frequently met in the woods about Oberlin. It is resident where it occurs at all, remaining in the deep woods. Its drum call is familiar to every countryman.

Family Phasianide, Turkeys.

11\%. (310a.) Meleagris gallopavo sylvestris (Vieill.). 181.

Wild Turkey.

Synonyms: Meleagris gallopavo var. americana, M. gallopavo, M. g. var. gallopavo, M. fera, M. gallopavo fera.

Common Wild Turkey, Eastern Wild Turkey.

Bonaparte, Am. Orn., I, 1825, 80.

This, the noblest of the game birds, is all but extinct within the state. It should not be placed upon the list of extinct species until the southern counties between the Scioto river and Cincinnati have been more thoroughly worked. It may be present there still.

\section{Order COLUMB无. Pigeons.}

Of the two members of this order found in Ohio only one is now numerous enough to receive attention as regards its food. That has been done under the discussion of the species. It is noteworthy that in the eastern parts of the United States the Mourning Dove builds its nests well above the ground, almost always, but in the west on the ground, and in the middle west indifferently on the ground or above it. Of course there are exceptions in each region.

118. (315.) Ectopistes migratorius (Linn.). 179. Passenger Pigeon.

Synonyms: Ectopistes macrura, Columba migratoria. Wild Pigeon.

Wilson, Am. Orn., I, 1808, 102.

This once extremely abundant species is now of casual 
occurrence during the migrations. It is likely that scattering records of single individuals or very small companies may be made from time to time. Many localities on the Western Reserve have their histories of great flights and immense rookeries. Before they have entirely passed from the memory of those who knew of them personally these places should be mapped for future reference.

119.

(316.) Zenaidura macroura (Linn.). 180. Mourning Dove.

Synonyms: Zenaidura carolinensis, Columba carolinensis, C. macroura.

Carolina Dove, Turtle Dove, Wild Dove.

Kirtland, Ohio Geol. Surv., 1838, 164.

The Mourning Dove ranks well up among the familiar birds, because it frequently nests in the orchard or shrubbery in towns and the suburbs of cities. It is a familiar bird along country roads in summer, taking dust-baths or gleaning for food. A few hardy individuals remain even in the extreme northern parts of the state all winter, but many pass the winter in the southern parts of the state. The bulk of the migrations occur about the middle of April in Lorain county. It is impossible to tell when the most go south, because they are so quiet about it. Few are seen during the molting period, which begins after the last brood is raised, and nests with eggs are found even during the first week in September.

Observations upon the food of the doves and examinations of their stomachs prove that while in spring and summer a good deal of wheat is eaten, by far the largest proportion of the dove's food consists of the seeds of noxious weeds. Undoubtedly the most of the wheat eaten is what the birds find among the stubble after the crop has been harvested. I have many times flushed doves from cornfields, during July and Augus $\bar{t}$, and found that they were eating the partly ripe seeds of the grasses which are the plague of the farmer's life. The Mourning Dove seldom occurs in flocks of any size, and therefore any depredations upon grain fields will hardly be noticed. 
ORdER RAPTORES. Birds of Prey.

Suborder SARCORHAMPHI. American Vultures.

Family Cathartide. American Vultures.

120. (325.) Cathartes aura (Linn.). $17 \%$ Turkey Vulture.

Synonyms: Vultur aura, Rhinogryphus aura.

Turkey Buzzard.

Wilson, Am. Orn., IV, 1812, 89.

The Turkey Vulture is fairly common during the summer throughout the state, even to the lake shore, the books upon birds to the contrary notwithstanding. During my residence at Oberlin, beginning in 1890 , it has been almost common, nesting in fallen hollow logs or hollow stumps. It remains all winter in the southern parts of the state, but is absent in winter north. I have found it as early as the 7 th of March at Oberlin.

Its habit of feeding on carrion is well known.

If the birds are too far away for one to see the bare head, the soaring flight without any flapping of the wings, or only an occasional stroke to regain balance, readily identifies the species. The hawks soar, it is true, but they also flap their wings a good deal, or soar in circles, while the vulture soars almost straightaway, without wing strokes.

121. (326.) Catharista urubu (Vieill.). 178. Black Vulture.

Snyonyms: Carthates atratus, C. iota, Catharista atrata, Vultur atratus.

Carrion Crow.

Audubon, Orn. Biog., II, 1834, 33.

The foregoing reference by Audubon that this species summers in Ohio as far as Cincinnati; three specimens seen by Dr. Langdon, "On or about December 20, 1876," one of which he secured on January $1,187 \%$, it having been killed a few days previous by Mr. Edwin Leonard, of Madisonville; and a specimen in Mr. Oliver Davie's collection, killed 
February 6, 1895, four miles north of Reynoldsburg, seem to constitute the Ohio records for this southern species.

Suborder FALCONES. Kites, Hawks, Eagles,. Falcons, Osprey.

Family Falconides. Same as above.

The food habits are fully given under each species.

122. (32\%.) Elanoides forficatus (Linn.). 166. Swallow-tailed Kite.

Synonyms: Falco furcatus, Nauclerus furcatus, Falco forficatus. Wilson, Am. Orn., VI, 1812, 70.

Writing in 1812, Wilson said that this Kite "is very ahundant in South Carolina and Georgia, and still more so in West Florida, and the extensive prairies of Ohio and the Indiana Territory." Dr. Kirtland found it "in considerable numbers in Portage and Stark counties". in the middle thirties, but noted its absence in 1838. Mr. Kirkpatrick found it occasionally in Crawford county, where it had been numerous before, in 1858. This was the last seen of this elegant bird until a specimen came into Dr. Wheaton's hands from Pataskala, where it was killed August 22, 1878. Twenty years later in August, 1898, Rev. W. F. Henninger notes a specimen shot in Ross county near Chillicothe. This seems to close the records to date.

123. (331.) Circus hudsonius (Linn.). $16 \%$. Marsh Hawk.

Synonyms: Circus cyaneus var. hudsonius, Falco cyaneus, F. hudsonius.

Marsh Harrier, Harrier, Mouse Hawk, Blue Hawk, American Marsh Hawk.

Kirtland, Ohio Geol. Surv., 1838, 161, 178.

In habits this hawk is unlike any of the other hawks. It lives in the open country, nesting and perching on the ground. It may always be known by its white rump spot or patch, and by its relatively small body and long, pointed 
wings and long tail. It flies more like a swallow than a hawk, as it skims over the meadows or sweeps upward and away with graceful, easy strokes. It is hardly common generally over the state, but is found in considerable numbers in especially favorable places.

The food of this hawk proves it to be one of the most beneficial of all our predaceous birds. It does sometimes eat poultry and small birds, but the proportion of these to the whole food of mice, snakes, insects, and squirrels is so small that it should not count against him. While their young were still in the nest $I$ have seen the male return from a search over the meadows with a good-sized snake, apparently not yet dead, in his talons, and drop it from a considerable height to the female who would always catch it before it reached the ground.

The Marsh Hawk is not a common winter resident, even in the southern counties, and breeds but rarely if at all there. It passes north early in March, reaching the lake shore before the first of April, sometimes as early as the last week in February. It has not been found in Lorain county after the middle of October.

124. (332.) ACcipiter velox (Wils.). 169. Sharp-shinned Hawk.

Synonyms: Accipter fuscus, Falco velox, Falco fuscus, Nisus fuscus.

"Pigeon Hawk."

Kirtland, Ohio Geol. Surv., 1838, 161, 178.

This little hawk is hardly common anywhere in the state, but it is everywhere present all the year. While it prefers the woods, skulking through the smaller growth low down if it has been feeding, it may often be seen flying across the open. In flight it may be known from the Sparrow Hawk by its larger size, long barred tail, lack of reddish in the feathers of the back, and by the fact that it does not hover over the meadows but skulks in the woods.

It lives principally upon small birds and young poultry and English Sparrows, only occasionally killing mice and 
other small mammals. It is distinctly injurious, but is becoming less so in winter because it now prefers English Sparrows to other birds. It is therefore becoming more numerous in the cities and towns and less so in the country. If he will only grow fonder of the sparrow pests and leave the young poultry alone we can easily forgive the past and give him encouragement for the future.

125. (333.) ACCIPIter COOPERII (Bonap.). 168. Cooper Hawk.

Synonyms: Falco cooperi, Astur cooperi, Nisus cooperi.

Chicken Hawk, Big Blue Hawk, Big Blue-tailed Hawk, Longtailed Dart, Darter.

Kirtland, Ohio Geol. Surv., 1838, 164, 179.

This medium-sized hawk is more often found in the woods than elsewhere. Indeed, it is seldom seen out of the woods except while it is soaring up almost out of sight, or while it is making a raid upon the poultry yard. It differs from the Sharp-shinned Hawk in having a long, rounded tail and rounded instead of rather pointed wings. To one who knows these two birds there is no difficulty in identifying them, but the difference is hard to explain. In general, the Sharp-shinned gives the impression of sharp angles with its pointed wings and square cut tail, while the Cooper has a decidedly rounded outline for both wings and tail. The Cooper is a larger bird. Its metallic "tic, tic, tic, tic," is its characteristic call, usually uttered during the breeding season.

This hawk is a common resident in the southern parts of the state, but is rare in winter north of Columbus. The individuals which migrate reach Oberlin about the middle of April, and depart late in October.

Like the Sharp-shinned, this hawk lives principally upon small birds, poultry also composing a large share of its food. It occasionally eats snakes and small mammals, but distinctly prefers the hot-blooded birds. If it eats English Sparrows their numbers must be small, because it does not come into the cities and towns for them. The maledictions heaped 
upon him are his death knell. We can only hope that he will not take down with him the manv hawks which are distinctly beneficial, thus depriving us of Nature's balancers for the injurious rodents and larger insects.

\section{6. (334.) Accipiter atricapillus (Wils.). 170. American Goshawk.}

Synonyms: Astur atricapillus, Falco palumbarius, A. p. var. atricapillus.

Goshawk, Blue Hen Hawk, Chicken Hawk.

Kirtland, Ohio Geol. Surv., 1838, 161, 178.

The Goshawk is so much like the Cooper Hawk that it is not known by more than a few of the more experienced Ohio ornithologists. It is larger, with a relatively shorter tail, and the general color is bluish-slate, so much so that the bird is often called the "Blue Hawk." It is much more northern in its distribution, reaching Ohio only in winter, and then occurring over the entire state in small numbers. It seems likely that some of the northern winter records for the Cooper Hawk may really be for this species. The records of its occurrence in the state are too few to make any statement of the time when it may be expected to reach the state from the north reliable. It seems likely that it arrives with the first cold and snow.

In food habits this species resembles the Sharp-shinned and Cooper Hawks, but its larger size necessitates larger quarry. It lives principally upon birds, the grouse forms contributing the most to its bill of fare. It can easily make off with an ordinary sized chicken, which it is very willing to come into the barn-yard for. It is so bold a hunter that the presence of man seems to make no difference whatever. Many instances have been recorded when it has picked up a chicken from the ground at the feet of persons who were feeding the flock. The Ptarmigan and Ruffed Grouse are favorite tidbits in its summer home. In summing up the evidence Dr. Fisher says: "Little can be said in favor of this Hawk, as the destruction of a few injurious rodents is a very meager offset for the great number of game birds 
and poultry it destroys." Fortunately it is not numerous enough in our state to inflict any appreciable damage.

12\%. (33\%.) Buteo borealis (Gmel.). 171.

Red-tailed Hawk.

Synonyms: Buteo aquilinus, Falco borealis, F. aquilinus. Red-tailed Buzzard, Hen Hawk.

Kirtland, Ohio Geol. Surv., 1838, 161, 178.

This large hawk appears to be migratory to some extent, passing farther south in winter when the ground is covered with snow. However, it is a fairly common resident over the entire state. It is sometimes absent from the northern counties for two or three weeks during the period of snow covered ground, usually in the early part of February. It has the undeserved title of "Hen Hawk," which should be transferred to the Goshawk. While it is true that this large hawk sometimes feeds upon poultry in' some regions more than in others, it clearly prefers other quarry. Dr. Fisher says, "Abundant proof is at hand to show that this Hawk greatly prefers the smaller mammals, reptiles and batrachians, taking little else when these are obtainable in sufficient numbers; but if hard pressed by hunger it will eat almost any form of animal life, such as poultry and other birds, insects, crawfish, or even offal or carrion. .... It is to be remarked that young Hawks are less particular as to the character of their food, and they are more frequently found to be the depredators of the poultry yards." Rev. Mr. Henninger has found that in southern Ohio, at least in Pike and Scioto counties, the Red-tails feed almost exclusively upon birds and poultry.

With the evidence all in we must say that while this large hawk is sometimes a menace to the poultry yard and at such times must be killed, it is generally far more beneficial than injurious, and therefore should not be persecuted unto death whenever found.

This hawk may be seen' soaring in ascending spirals almost anywhere in any region of the state on fair days. It nests in the woods, but apparently feeds as much in the open 
fields as in the woods. It may be easily distinguished from the other large hawks by the bright rufous of its tail, which may have a band of dusky near the tip.

128

(339.) Buteo lineatus (Gmel.). 172. Red-shouldered Hawk.

Synonyms: Falco hyemalis, F. lineatus, F. buteodes. Red-shouldered Buzzard, Winter Hawk, Chicken Hawk.

Kirtland, Ohio Geol. Surv., 1838, 161, 178.

In northern Ohio this hawk is the most numerous large hawk, the little Sparrow Hawk alone outnumbering it. It is less common during the winter than during the summer, and may be absent for three or four weeks in the latter part of January and February when the cold is severest. It seems to be much less common, if present at all, in the southern part of the state in summer. I did not see it along the Ohio river in August. It may be known from the other large hawks by the lack of any rufous on the tail and by the moderate length of its tail. Its cry is pil ye, pil ye, differing from the cry of the Red-tail, which is a continuous scream.

There seems to be no evidence that this hawk eats poultry. Dr. Fisher states that it eats mammals, birds, snakes, frogs, fish, insects, centipeds, spiders, crawfish, earthworms, and snails. Its food is therefore more varied than that of any other member of this order. It is distinctly beneficial, and if injurious at all so very little so that it may not be counted as cause for the death sentence except on the rarest of occasions.

The general habits of this hawk resemble those of the Red-tail, but its nest is not placed so high, usually, and it is not quite so wary.

129. (343.) Buteo platypterus (Vieill.). 173. Broad-winged Hawk.

Synonyms: Buteo pennsylvanicus, Falco pennsylvanicus, F. latissimus, B. latissimus.

Broad-winged Buzzard.

Kirtland, Ohio Geol. Surv., 1838, 161, 178. 
This is another little known hawk, not because it is rare, for it is present in some numbers throughout the state, but because it apparently differs but little from several other middle-sized hawks. It is about the size of the Cooper Hawk, but differs from that species in having a much shorter tail and in having the wings more slender and therefore more pointed instead of rounded. It differs from the Sharpshinned in being larger and in its habit of soaring like the other hawks of the genus Buteo. Perhaps the most reliable character is its unsuspiciousness of man. It will permit a near approach without manifesting either uneasiness or curiosity.

Dr. Fisher says : "The food of this hawk consists principally of insects, small mammals, reptiles, and batrachians, and occasionally of young or disabled birds. A specimen secured by the writer just after a shower was gorged with earthworms. In spring when toads frequent ponds to spawn, it devours large numbers of them, and later in the season it is a not uncommon occurrence to see an individual with a snake or frog dangling from its talons." Probably the greatest service which this hawk renders is in the destruction of large numbers of the large insect larvæ which most birds do not touch. While it eats some animals which are beneficial it is too useful a bird to be killed indiscriminately, but should be accorded protection.

This hawk should be found wintering in the state south of Columbus, but probably in small numbers. It reaches northern Ohio in the spring about the middle of March, and has gone south again by the middle of November.

130

(34\%a.) Archibuteo

LAGOPUS

SANCTI-JOHANNIS (Gmel.). 174.

American Rough-legged Hawk.

Synonyms: Falco sancti-johannis, Archibuteo sancti-johannis,

A. lagopus.

Rough-legged Buzzard, Black Hawk.

Kirtland, Ohio Geol. Surv., 1838, 161, 178.

This large hawk occurs only during the winter, when it 
ranges across the state. Being semi-nocturnal in habits it is not often seen by those who go out only during bright day, and so is regarded rare or absent from many regions where it undoubtedly occurs. I have found it in Lorain county only after the holidays, usually in late winter and early spring. In feeding habits it somewhat resembles the Marsh Hawk, beating low over the meadows and fields and pouncing upon the mice and moles from its low flight.

Dr. Fisher says: "Its food consists principally, if not almost exclusively, of the smaller rodents, and most prominent among them are the arvicoline mice and lemmings." It is therefore clear that this hawk should be welcomed to our fields and meadows and orchards where these pests abound.

Probably the chief character which will distinguish this large hawk from all the others in flight is its dark color. It is so much smaller than the eagles that the comparison would appeal to any one at once.

\section{1. (349.) Aquila chrysaetos (Linn.). 175. Golden Eagle.}

Synonyms: Aquila chrysaetus var. canadensis, Falco fulvus, F. chrysaetus, Aquila canadensis.

Ring-tailed Eagle.

Kirtland, Ohio Geol. Surv., 1858, 67, 177.

It is not at all likely that this eagle nests in the state. It seems to be a rare winter visitor, but is reported from all sections. Mr. Harry B. McConnell tells me that three have been captured in the vicinity of Cadiz within the past three years. I have four records for Lorain county within the last five years. One was shot, not far from Oberlin, in the act of carrying off a hen from a barn-yard.

"The food consists mainly of mammals and birds, of which spermophiles, rabbits, fawns, lambs, turkeys, water fowl and other large birds form the principal part, though offal and carrion are sometimes taken.

"To sum up, it may be stated that in sections of the country where rabbits, prairie dogs and gophers are abundant 
the Golden Eagle is very beneficial, confining its attention mainly to those noxious animals; but in places where wild game is scarce it is often very destructive to the young of domesticated animals, and hence in such places has to be kept in check." (Fisher.)

There are many accounts of the ferocity and cruelty of this large bird of prey, some of which are probably true. It has been known to kill a good sized black-tailed deer, and in rare instances to attack a man who interfered with it while it was feeding. Even in defense of its young it is usually not courageous but an arrant coward. It is more than likely that the accounts of the capture of children by this bird are good illustrations of vivid imagination. While a hungry bird might pounce upon an unprotected infant it is extremely unlikely that a child old enough to walk would be molested.

132. (352.) Halizetus leucocephalus (Linn.). 176. Bald Eagle.

Synonyms: Falco leucocephalus, F. washingtonianus, F. washingtonii.

Whie-headed Eagle, Bird of Washington.

Wilson, Am. Orn., IV, 1812, 890.

While the Bald Eagle is common near Sandusky and among the islands north of there, it is rare in the other parts of the state. It does not seem to migrate southward in winter, but is strictly resident wherever it occurs. The two eagles are too large to be confused with the hawks, and the white head and tail of this species is wholly distinctive.

"The favorite food of the Bald Eagle is fish, and where this vertebrate can be procured the bird will touch little else. Of the hundreds of these Eagles which the writer has watched, none were observed ever to touch anything except fish or offal picked up from rivers or along their shores. What proportion of the fish consumed is taken from the Osprey is hard to estimate, but the number must be very great.

"What we have "said in" reference to the Golden Eagle 
applies equally well to the bird under consideration, namely, that over the greater part of the country where the natural food, fish in the present case, is abundant it is a harmless bird and should be protected; while in sections where it is injurious to sheep or other domesticated animals it should not be allowed to become numerous." (Fisher.)

There seem to be several well authenticated instances when this eagle has attacked human beings, for one cause or another, but it is equally true that it does not often do so. Indeed, the provocation would have to be great, for the birds are usually cowards in the presence of man.

It is well known that the Bald Eagle's regular practice is to wait until the Osprey has captured a fish when the eagle attacks him and forces him to drop it, whereupon the eagle secures it for himself. While it is hard on the Osprey it is easy for the eagle.

\section{3. (356.) Falco peregrinus anatum (Bonap.). 162. Duck Hawk.}

Synonyms: Falco communis var. anatum, Falco peregrinus nævius, F. peregrinus, F. anatum, F. communis.

Peregrine Falcon, Great-footed Hawk, Wandering Falcon. Kirtland, Ohio Geol. Surv., 1838, 161, 178. .

The Duck Hawk seems to be the least known of our smaller hawks, yet it must be pretty well distributed over the state, at least in winter. It is one of the most fearless of our birds of prey, and a true Falcon in its swiftness of wing, quickness, and dash. It is able to overtake and kill a pigeon or teal in full flight. Nothing seems able to escape by its swiftness alone. It is also persistent to the last degree, following a flock of ducks or other birds for miles, often for days, killing whenever hungry. Hunters often complain that their kills have been seized by this hawk from under their hands.

Concerning the actual records for this hawk within the state there is little to say. Mr. Dury has taken several specimens at St. Mary's reservoir; Dr. Jasper took one at Columbus; there is a specimen in the collection of $\mathrm{Mr}$. 
A. Hengartner, of Lorain, taken near the lake shore; and a specimen was taken in one of the State University buildings during the winter of 1902-3. Mr. W. L. Dawson reports one positively identified, at Columbus, March 5, 1902. There are reports of other birds having been seen, but if there have been any captures they have not been reported. Dr. Wheaton supposed that it might be found nesting in the northwestern part of the state, but if it does it is unknown to me.

The large size for a Falcon and the boldness and swiftness of this hawk are about all the field characteristics that I can give. It could not be taken for one of the Buteo group, nor for anything but a Falcon. It is the largest of that group inhabiting Ohio.

"The food of this hawk consists almost exclusively of birds, of which water-fowl and shore birds form the greater part. In sections of the country where its nest is surrounded by cultivated lands, the bird is bitterly complained of by .the farmers on account of its inroads on the poultry." (Fisher.)

\section{4. (35\%.) FAlCo COLUmbarius Linn. 163.} Pigeon Hawk.

Synonyms: Asalon columbarius, Hypotriorchis columbarius, Falco lithifalco var. columbarius.

Kirtland, Ohio Geol. Surv., 1838 161, 178.

This little Falcon appears to be rare in the state, as a migrant or winter resident everywhere except in the northern tier of counties where it has been found breeding rarely. There are generally several records each winter near Oberlin. During the migrations it may be found near or even traveling a little behind the flocks of blackbirds and other small flocking birds, preying upon them. It should be found during the winter in the southern parts of the state pretty regularly, but in small numbers.

"The food of the Pigeon Hawk consists mainly of small and medium sized birds, especially the gregarious species, insects, and occasionally small mammals. Pigeons, Flickers and Grackles are about as large birds as it usually attacks, 
though Dr. Dall in one instance sà it kill a Ptarmigan, and Dr. E. A. Mearns speaks of a specimen shot in the act of destroying a hen. Among insects dragon flies are favorite morsels for this Hawk, and the apparent ease with which it captures these nimble winged insects demonstrates better than anything else its remarkable power of flight. The writer has also found grasshoppers, crickets and beetles among the stomach contents." (Fisher.)

- It is not easy to distinguish between this and some others of the small hawks. However, this is one of the smallest and darkest, with the habits of a Falcon, snatching its prey from the ground or in the air without stopping its flight instead of pouncing upon it and bearing it down by its weight.

\section{5. (360.) Falco sparverius Linn. 164. ... American Sparrow Hawk.}

Synonyms: Tinnunculus sparverius.

Sparrow Hawk, Rusty-crowned Falcon.

Kirtland, Ohio Geol. Surv., 1838, 161, 178.

This is universally conceded to be the commonest of our hawks. It is common everywhere during the summer, but is less common in the northern third of the state in winter than in summer. It frequently comes into towns and city parks at almost any time, to catch English Sparrows, and is therefore seen by many persons who know nothing about any other hawks. It is readily. distinguished from all other hawks by its bright rufous back and tail, and in the field by its habit of hovering over a meadow as it scans the ground for a mouse or insect. I have seen one spend an hour looking pver a ten-acre field in this way, hovering in one place for about a minute, then change its position and hover again, and finally fly to another field when unsuccessful.

"The Sparrow Hawk is almost exclusively insectivorous except when insect food is difficult to obtain. In localities where grasshoppers and crickets are abundant these hawks congregate, often in moderate sized flocks, and gorge themselves continuously. Rarely do they touch any other kind 
of food until, either by the advancing season, or for other natural causes, the grasshopper crop is so lessened that they can no longer appease their hunger except by undue exertion. Then other kinds of insects and other forms of life contribute to their fare; and beetles, spiders, mice, shrews, small snakes, lizards or even small birds are required to bring up the balance." (Fisher.) It therefore seems certain that the farmer has no better friend than this little Falcon. He may rarely exact toll in the form of chicken meat, but that should no more count against the whole group of Sparrow Hawks than an occasional chicken stealing cat should count against all cats.

While this hawk nests in hollow trees in the woods, or more properly on the borders of woods preferably, it is more often seen in the open than in the woods, except when nesting. It feeds in the open then but stays near home.

136. (364.) Pandion haliaetus carolinensis (Gmel.). 165.

\section{American Osprey.}

Synonyms: Pandion haliaetus, Falco haliaetus, Pandion carolinensis, Falco carolinensis.

Fish Hawk, Osprey.

Kirtland, Ohio Geol. Surv., 1838, 161.

The Osprey is not common anywhere in the state, but it is likely to be present wherever fish are to be found near the surface of the water. It should breed at the large reservoirs and lakes, but there are no such reports from those regions. It is found all summer at the lake shore, but I am not aware that a nest has actually been found. Rev. Mr. Henninger states that it occurs in Scioto and Pike counties during the winter and during the spring and autumn migrations in some numbers, feeding along the Scioto river. It visits the Oberlin water-works reservoir pretty regularly the first or second week in May, often tarrying for several days in the vicinity because the fish are so numerous and so easy to catch.

The Osprey's food is exclusively fish, almost always cap- 
tured alive, but rarely dead ones are picked up from the surface of the water if the bird is hard pressed for food. I have seen it catch fish so large that it was barely able to get out of the water with its catch. There are instances when the bird has struck so large a fish that, unable to loosen his hold, he has been drawn under the water and drowned. Large fish have been washed ashore with an Osprey still clinging to them in death, the claws set too firmly in flesh and scales to be loosened.

It has been stated that where Bald Eagles are found there the Osprey will be also. That has not proved true in the region of Sandusky where the eagles are more numerous than elsewhere in the state. Perhaps the Ospreys have learned to avoid that region.

\section{Suborder STRIGES. Owls.}

Family Strigide. Barn Owls.

13\%. (365.) Strix pratincola Bonap. 152.

: $\quad$ American Barn Owl.

Synonyms: Strix flammea var. americana, S. flammea, Aluco flammeus americanus.

Barn Owl, Monkey-faced Owl.

Kirkpatrick, Ohio Farmer, VIII, 1859, 35.

"Rare visitor. Not over half a dozen individuals recorded." (Wheaton.) There has been a very manifest increase in the numbers of this owl since Dr. Wheaton wrote the above quotation. It is now almost common in the southern parts of the state, being even common locally. In the northern half of the state it is generally reported as rare. Numbers of specimens have been taken along the whole lake front. It is resident-everywhere, and will usually be found in barns and church steeples or similar places where it spends the day, sallying forth at dusk for its daily catch of rats and mice.

The bird may be known at once by its "monkey face," lack of ear tufts, and bright reddish-brown color. It is 
considerably larger than the Screech Owl, which may be reddish, but has ear tufts.

(1:"All testimony goes to show that the Barn Owl is one of the most beneficial of rapacious birds. ..... Its food undoubtedly consists principally of several species of rodents which, from their great number and destructive habits, are a curse to the country they inhabit. .... In the east its food consists largely of mice and rats which it destroys with as much energy as it does the gophers of the west. All the common species, including the meadow, house, and white-footed mice, as well as the common rat are eaten with equal relish" (Fisher). Mr. Charles Dury gives an account of a colony of these owls which lived in the town hall in Glendale, Ohio, in which he says, "But the strangest part of the curious habitation was the flock of domestic pigeons that were living seemingly on intimate terms with the owls, and, judging from the old pigeon nests, I presume the pigeons had actually nested and reared their young there. The floor where they lived was literally covered with the pellets which the birds had disgorged, after the manner of the owl tribe." It seems to be beyond question that one Barn Owl is worth a whole family of cats as a mouser, and that it is far less likely to steal a chicken than the average cat is.

Family Bubonids. Other Owls.

138. (366.) Asio wilsonianus (Less.). 153. American Long-eared Owl.

Synonyms: Otus vulgaris var. wilsonianus, Asio americanus, Otus vulgaris, $\mathrm{O}$. wilsonianus.

Long-eared Owl, Cat Owl.

Audubon, Orn. Biog., IV, 1838, 572.

One must look in the woods for this owl, where it nests and where it feeds by night and rests by day. It is not common anywhere in the state, but is pretty generally distributed. In Lorain county it has been found both singly and in companies of six individuals in winter, and its cry is sontimes heard during the summer while it is nesting. It 
inhabits the stream gorges in which there is a considerable growth of evergreen trees, in winter, and may be closely approached there. While it is strictly-nocturnal it can see well enough in bright sunlight to thread its way in rapid flight through the mazes of the trees. Its confidence in its protective colors and attitude often proves fatal.

This owl may be identfied in the field as a mediumsized bird with conspicuous ear tufts. The only other owls with conspicuous ear tufts are either so much smaller or so much larger that one should have no difficulty in making the determination.

"The Long-eared Owl is one of our most beneficial species, destroying vast numbers of injurious rodents and seldom touching insectivorous birds..... As this owl is readily destroyed, it is the one that suffers most when shortsighted legislators enact laws for the destruction of the birds of prey. ...... It is both cruel and pernicious to molest a bird so valuable and innocent as the one under consideration." (Fisher.) Like other birds of prey, this owl will attack poultry or even small dogs when hard pressed for food. Insects may form a fair proportion of the summer diet of these birds where they are easier to obtain than rodents.

139

(36\%.) Asio accipitrinus (Pall.). 154.

Short-eared Owl.

Synonyms: Brachyotus palustris, Strix brachyotus, Brachyotus cassinii, Otus brachyotus, Strix accipitrinus.

Marsh Owl, Prairie Owl.

Kirtland, Ohio Geol. Surv., 1838, 161, 179.

This owl is just as truly a bird of the open fields as the Long-eared is of the woods. It even nests on the ground, and roosts under overhanging banks in almost any ditch or considerable gorge. In Lorain county I have never seen more than two together, and they on the lake shore in winter. Several are seen winter or early spring, but it must be regarded as' uncommon if not rare. I have never seen it in summer. It appears to be common during the win- 
ter in some parts of the southern counties, and likely nests in the more extensive prairies and swampy regions. It may be known by its habit of feeding during the early forenoon and late afternoon in broad day, and by its habit of feeding in the fields. While it has ear tufts they are too small to be seen unless the bird raises them in excitement.

"The food of this Owl consists largely of mice and other small mammals. A number of species of insects, birds, and reptiles also may be mentioned as occasionally contributing to its fare. Fully 75 per cent of the stomachs examined in the Department of Agriculture contained mice.... Of the other mammals which this Owl feeds upon may be mentioned shrews, gophers, and sometimes small rabbits." (Fisher.) The verdict is clearly for protection of this owl, even if he does sometimes kill useful animals.

\section{0. (368.) Syrnium varium (Barton). 155. Barred Owl.}

Synonyms: Strix nebulosa. Syrnium nebulosum.

Hoot Owl, American Wood Owl, Round-headed Owl. Kirtland, Ohio Geol. Surv., 1838, 161.

This is the most common large owl, and stands next to the Screech Owl in numbers. It is strictly resident throughout the state, and as strictly arboreal. It is nocturnal, but sometimes feeds during dark days or at twilight. Its cry "who cooks for you, who cooks for you, who!" may be heard in almost any large woods during the early evening or early morning hours, while its blood-curdling caterwaulings are more often reserved for the small hours when the camper is sure to be asleep' In these later days some of the thrilling accounts of "encounters" with wild cats and panthers in the more settled districts of the state are traceable to the night calls of this owl. Certain it is that a sudden awakening in the wee hours with the unearthly squalls from this owl, perched just overhead, ringing in your ears, meets instant response from your hair!

"In summing up the facts relating to the food habits of this Owl it appears that, while the general statements of 
certain authors, especially the earlier ones. charge the bird with destruction to poultry, game, and small birds, such destructive habits are comparatively uncommon. That it does occasionally make inroads upon poultry yards, and does more or less damage among game birds, is true; but the systematic collection and examination of a large number of stomachs show the exceptional character of such acts and reveal the fact that the larger part of the food consists of mammals. And it is to be noted that among the list are some of the most destructive rodents the farmer has to contend with. If a fair balance is to be struck, therefore, it must be considered that this Owl is on the whole beneficial, and hence should occupy a place on the list of birds to be protected." (Fisher.)

\section{1. (3\%0.) Scotiaptex nebulosa (Forst.). 156. Great Gray Owl.}

Synonyms: Syrnium cinereum, Ulula cinerea, S. lapponicum var. cinereum, Strix cinerea. Scotiaptex cinerea.

Spectral Owl.

Kirkpatrick, Ohio Farmer, VIII, 1859, 107.

The records given by Dr. Wheaton remain the only ones for the state. They are: Mr. Kirkpatrick, Huntsburg, Geauga county; and Mr. Charles Dury, Clarke county. It must therefore be regarded as a casual visitor.

142. (372.) Nyctala acadica (Gmel.). $15 \%$. Saw-whet Owl.

Synonyms: Nyctale acadica, Strix acadica, Ulula acadica. Acadian Owl.

Audubon, Orn. Biog., II, 1834, 537.

This little owl, the smallest of the group in Ohio, is almost wholly a winter resident in the state, breeding only rarely in the northern counties. It is probably more numerous than the reports show, for it is the most strictly nocturnal of the owls, and therefore seldom seen. Its small size is also a good protection from prying eyes. Like the Barred Owl, it has no ear tufts. It seems partial to evergreen 
woods, but has been found on several occasions in an outhouse of one of the lake summer resorts. The most of the reports of its occurrence fall within the colder part of the year, but it has been seen at Cincinnati in May (Dury), and it was found in May at Licking reservoir (Dawson).

"The food of this little Owl is composed almost wholly of mice, of which the wood-dwelling species seem to predominate. At times it attacks larger mammals, such as rats, halfgrown red squirrels and chipmunks. .... It rarely molests small birds; unless its favorite food-mice-for some reason, is scarce. Occasionally it feeds on scraps of raw or cooked meat which it has been observed to pick up in the vicinity of camps, and in winter, in the north, it will feed on the carcasses of comparatively large animals: .... It also feeds to some extent on insects of various kinds. Thus it will be seen that while the diminutive size of the Sawwhet limits its powers of usefulness, its mode of life renders it a useful adjunct to the farmer, and, small though it be, yet in districts where it abounds the number of mice it annually destroys must be very large.” (Fisher.)

\section{3. (373.) Megascops $\Lambda$ Sio (Linn.). 158. Screech Owl.}

Synonyms: Scops asio, Strix nævia.

Mottled Owl, Little Horned Owl, Red Owl.

Kirtland, Ohio Geol. Surv., 1838, 161, 179.

This is one of the most numerous and best known of our owls, and is the bird from which most persons get their idea of what an owl is like. In the more settled districts this owl seems to prefer to live in buildings other than dwellings, or in hollow shade trees. There are numerous instances of captures during the evening church service which, from all accounts, left neither the owl nor the audience in a worshipful frame of mind! The natural home of the Screech Owl is the deeper woods, where it frequently roosts and always nests in hollows in trees. It also spends the day in some thick foliaged tree. On the Oberlin College campus a male is in the habit of spending the day in 
an evergreen near the main walk leading from the Library to the Chapel building. His presence would never be suspected if the Blue Jays would mind their own business instead of his. This pair rears its brood in the loft of either French Hall or the Chapel.*

This little owl may be known by its conspicuous ear tufts and reddish or grayish mottled plumage. Its quavering call is often heard during the spring months.

"Their food consists of a great variety of animal life, including mammals, birds, reptiles, batrachians, fish, crustaceans, and insects. . . . . Their economic relations, therefore, are of the greatest importance, particularly on account of the abundance of the species in many of the farming districts, and whoever destroys them through ignorance or prejudice should be severely condemned." (Fisher.)

144. (375.) Bubo virginianus (Gmel.). 159. Great Horned Owl.

Synonyms: Strix virginanus.

Hoot Owl, Cat Owl, Hooter.

Wilson, Am. Orn., 1812, 52.

This is the largest of our "horned" owls, and is generally reported as fairly common but disappearing near the large citits. It is rare in Lorain county, but three individuals being known in the western half of the county. Its large size should make it a conspicuous bird. I have found it only when crows and hawks have routed it from its retreat. It inhabits the larger, heavier woods, and is hardly more than semi-nocturnal, sometimes feeding by day. It nests indifferently in open nests or hollow trees.

It may be known at a glance by its white illroat patch, large ear tufrs, and powerful build.

"The food of this species is of great variety; birds and mammals as we!l as reptiles, fish, crustaceans, and insects contribute to its fare. Among the birds most often taken may be mentioned all kinds of poultry (including half-

* Since the above was written the chapel has burned. I am glad to report that the owl escaped unscorched. 
grown turkeys), grouse, quail, doves, and wild ducks. E.ren hawks, crows, and other owls do not escape the voracity of this tiger among birds, and the large hawks are anıong those attacked and eaten.

"Of all the birds of prey, with the exception possibly of the Goshawk and Cooper Hawk, the Great Horned Owl is the most destructive to poultry. Ail kinds of poultry seem to be taken, though when Guinea fowis and turkeys are obtainable it shows a preference for these." (Fisher.) While this bird does a great deal of grood in ridding the country of injurious animals, its natural taste for poultry sounds its death knell. We must feel a sort of compassion for him in his unequal struggle for life. He sees no reason for changing his manner of life and we cannot overlook his failings.

\section{5. (376.) Nyctea nyctea (Linn.). 160. Snowy Owl.}

Synonyms: Nyctale scandica, Nyctea scandiaca, N. nivea, N. scandiaca var. arctica, Surnia nyctea.

White Owl.

Wilson, Am. Orn. IV, 1812, 53.

The Snowy Owl visits the state only in winter and even then in small numbers unless there be some special provocation in the matter of failure of food supply farther north. It occasionally wanders completely across the state, but is clearly more numerous along the lake shore than in the interior. It also seems to be more numerous in the western third than farther east. We could hardly expect to find it except when the ground is covered, and the weather cold.

This bird is not pure white, but so near that color as to appear white. No one would confuse it with any other species of birds.

The favorite food of this large, smooth-headed owl seems to be mice and other rodents and fish. Its numbers in Ohio are too small to make it of any appreciable benefit, but it must be regarded as more beneficial than injurious. It probably does eat birds, and may even catch poultry on a pinch, but the numbers captured are very small. 
146. (37\%a.) Surnia ulula caparoch (Müll.). 161. American Hawk Owl.

S sonyms: Surnia ulula var. hudsonia $\mathbf{S}$. funerea, S. ulúla, Strix ulula, S. hudsonia, S. caparoch. Hawk Owl, Day Owl.

Kirkpatrick, Ohio Farmer, VIII, 1859, 67.

The above reference and the remark that "Mr. Langdon thinks that he has seen this species at St. Mary's reservoir," are all that Dr. Wheaton knew of this species as an Ohio bird. There is a specimen in Mr. R. E. Jump's collection, captured near Oberlin some twenty years ago. Messrs. C. H. Morris and E. J. Arrick report one in Morgan county during the winter 1901-02, which was not captured. It therefore appears that the only specimen which can be examined is the Jump specimen.

This owl is so named because in appearance and habits of feeding it resembles a hawk more closely than an owl. In habits it is almost wholly diurnal, feeding and flying from place to place in broad day.

While in the state its food consists of small mammals and birds. It is probably somewhat injurious, but its numbers are so small as to count for nothing economically.

Order COCCYGES. Cuckoos and Kingfishers.

Suborder CUCULI. Cuckoos.

Family Cuculide. Cuckoos.

14\%. (38\%.) Coccyzus americanus (Linn.). 149. Yellow-billed Cuckoo.

Synonyms: Cuculus americanus.

Rain Cuckoo, Rain Crow, Rain Pigeon, Wood Pigeon, Cowcow, Indian-hen.

Kirtland, Ohio Geol. Surv., 1838, 162.

This is the commoner of the two cuckoos in Ohio, and seems to be pretty uniformly distributed over the state during the summer. There is no evidence of an appreciable change in numbers since Dr. Wheaton's catalogue was published. 
It is well known that the cuckoos are fond of the "hairy" caterpillars, and destroy great numbers of them. I have seen one bird disposed of a moderate sized colony of tent caterpillars at one sitting, in the nesting season. Both cuckoos deserve protection and good treatment for their services in ridding us of many insects which most other birds will not touch.

". This is the darker of the two species, and in flight the wings show the rufous of the inner vanes of the feathers. The call is on a lower key, is given : slower and is not - phrased. It is only after some experience with the cuckoos that one can hope to be certain which species he has afield.

The migration records are far from satisfactory. They make it appear that the first arrive in the state shortly after the first of May and the last tarry until the third week in September. I have to say, however, that I have repeatedly found nests with eggs almost ready to hatch the first week in May, thus indicating an early April arrival.

148. (388.) Coccyzus erythrophthalmus (Wils.). 150.

Black-billed Cuckoo.

Synonyms: Cuculus erythropthalmus.

Rain Crow, Rain Dove, Chow-chow, Cow-cow.

Audubon, Orn. Biog., I, 1831, 170.

Dr. Wheaton's statement that this cuckoo is a very common summer resident throughout the state is no longer applicable. The reports from observers are nearly uniform in pronouncing it decidedly less common than the preceding species. In habits it is practically the same as the Yellowbilled. The cry is phrased instead of being uttered in a uniform monotone. 


\section{SUBORDER ALCYONES. Kingfishers.}

Family AlCEdinide. Kingfishers.

149. (390.) Cerlyle alycon (Linn.). 148. Belted Kingfisher.

Synonyms: Alcedo alcyon.

Kingfisher, Fisher.

Wilson, Am. Orn., III, 1811, 59.

The Kingfisher is a resident in favorable places, where open water may be found the winter through, and where fish are plentiful; but it is not known as a winter bird from most localities, simply because open water is not found in the coldest weather. In Lorain county there is no open water, regularly, even along the lake shore, where fish can be found;* but at Norwalk a pool which is fed by warm water from a manufacturing plant furnishes at least one Kingfisher with winter rations. In the southern part of the state it is more commonly found all winter and summer. Migrants reach Oberlin about the middle of March.

The Kingfisher feeds entirely upon fish, but cannot be considered in any degree injurious to the fishing industry.

*Since the above was written a pool of open water has been discovered about two miles north of Elyria where a Kingfisher spends the winter.

Order PICI. Woodpeckers, Sapsuckers and Flickers.

Family Picide. Woodpeckers.

150. (393.) Dryobates villosus (Linn.). 140, Hairy Woodpecker.

Synonyms: Picus villosus, P. rubricapillus.

"Sapsucker."

Kirtland, Ohio Geol. Surv., 1838, 162.

This is a common resident throughout the state, but apparently is less common in summer than in winter. Its secretive habits during the nesting season probably give a false impression. This and the next species frequent the 
orchards and shade trees during the winter and spring, sometimes nesting in old apple trees. Their search after insects within the bark of trees has earned for them the mistaken title of Sapsucker, and with the title a measure of persecution. It is doubtful whether either of these birds have ever done as much damage as good to the tree from which they have taken injurious insects. Wood-boring beetles, both adults and larvæ, caterpillars, mostly tree-burrowing, and wood-boring ants comprise the chief summer -food. It is therefore clear that this woodpecker is one of our best preservers of the forests. In winter they may eat nuts, frozen fruit, and weed seeds when insects are hard to find. They also eat the inner bark of some trees.

There seems to be no direct evidence that this and the next species migrate at all.

151. (394c.) Dryobates pubescens medianus (Swains.). 141.

Downy Woodpecker.

Synonyms: Picus pubescens, P. medianus, Dryobates pubescens.

"Sapsucker," Little Sapsucker, Small Sapsucker.

Kirtland, Ohio Geol. Surv., 1838, 162, 179.

This is the more familiar and better known of our two small winter woodpeckers. A little encouragement in the way of broken nut meats or suet tied or nailed to some tree or board placed for that purpose, will make him a regular winter visitor even to the window sill. In summer he is likely to choose a useless apple tree for his nest, if not startled away.

This and the preceding species troop through the woods, in winter, with the Chickadees, Tufted Tits, Nuthatches, and Goldfinches, and often others, making an otherwise dreary waste of timber full of life and interest.

In habits this little woodpecker resembles the Hairy closely, eating the same kind of food. It may be known from the Hairy by its smaller size and weaker bill, and higher pitched voice. 
152. (400.) Picoides arcticus (Swains.). 142. Arctic Three-toed Woodpecker.

Synonyms: Picus (Apternus) arcticus.

Black-backed Woodpecker, Black-backed Three-toed Woodpecker, Ladder-backed Woodpecker, Banded-backed Threetoed Woodpecker.

Wheaton, Ohio Agri. Report, 1860, 379, hypothetical.

Baird, Brewer, Ridgway, 1I, 1874, 531.

The specimen reported by Dr. Brewer in the second citation above, was taken at Akron, Summit county. Oberlin College has since come into possession of a specimen collected and mounted by Mr. John C. Catlin at Ravenna, Portage county. It is not unlikely that Mr. Catlin secured his specimen first, but this is the first mention of it in print.

Prof. J. S. Hine, of Columbus, gives it as occasional in Franklin county.

It would occur only in severe winters.

153. (402.) Sphyrapicus varius (Linn.). 143. Yellow-bellied Sapsucker.

Synonyms: Picus varius.

Yellow-bellied Woodpecker, Sapsucker, Common Sapsucker. Wilson, Am. Orn., I, 1808, 147.

This is the true "Sapsucker," and should not be confused with our familiar winter woodpeckers. It feeds upon the sap of the maple and pine trees in spring, and often causes some damage to the trees, sometimes girdling the tree with one or more rows of holes. It is undoubtedly true that the insects which swarm about the exuding sap are also eaten, so the object which the woodpecker has in view in tapping the tree may be twofold. During the rest of the year the birds eat insects, some mast, the inner bark of trees, and such vegetable food as can be found.

It is common as a migrant across the state, both spring and autumn, but nests in small numbers in the northern part of the state. It winters in small numbers in the southwest corner, reaching the lake shore in the northward migration during the middle of March. It crosses the state 
again during the first half of October. A few individuals remain in almost any locality all winter.

154. (405a.) Ceophlqeus pileatus abieticola Bangs. 144.

Northern Pileated Woodpecker.

Synonyms: Hylotomus pileatus, Picus pileatus, Ceophlœus pileatus.

Pileated Woodpecker, Logcock, Woodcock, Big Black Woodpecker, Black Woodpecker, King of the Woods, Cock of the Woods.

Kirtland, Ohio Geol. Surv., 1838, 162.

The decrease in the numbers of this species heralded by Dr. Wheaton in 1882, has gone on steadily, but less rapidly than during his long term of study. From all reports it is now almost gone from the northwestern parts of the state, but can be found in the eastern and middle-southern parts where some heavy timber is still allowed to stand. The cutting down of a large tract of swampy woods in Ashtabula county has driven some of the birds remaining there to the woods surrounding Jefferson, where Mr. Robert J. Sim enjoyed the rare opportunity of watching a pair at their household affairs during last spring. The writer saw the tree, in September of the same year, and listened to the weird laugh of the birds. If the woods are doomed the Pileated Woodpecker's days are numbered. We cannot but mourn the passing of this majestic "King of the Woods."

The food consists principally of the larvæ of wood-boring beetles, ants, and wild.fruits. It is, therefore, one of our best forest preservers.

155. (406.) Melanerpes erythrocephalus (Linn.) 146. Red-headed Woodpecker.

Synonyms: Picus erythrocephalus.

Red-head, Tricolor.

Kirtland, Ohio Geol. Surv., 1838, 162.

The Red-head is one of our commonest summer birds. It may fairly be called abundant after the young have left the 
nest, and until the first frosts give warning of the coming winter. It reaches southern Ohio about the 25th of April, and the northern counties within three days afterward. Frequently a few individuals remain all winter even at the lake shore, but the majority have left the northern regions before the last of September.

The Red-head is not quite a true woodpecker, since he does not search the bark of trees for insects and worms as much as he looks for them on posts and such surfaces, but he has developed the flycatcher habit of darting out for flying insects, catching them as adroitly as any Kingbird. The late General J. D. Cox told with evident relish how as a boy he took advantage of this flycatching habit to catch the bird. By tossing a small stone up past the bird alert upon the top of some broken topped dead tree, as the stone fell downward the bird would invariably dart out to catch it, but was stunned and fluttered to the ground only to be pounced upon and carried off in triumph by the young general!

"The Red-head makes the best showing in the kinds of insects eaten. It consumes fewer ants and more beetles than any of the other species, in this respect standing at the head, and it has a pronounced taste for beetles of very large size. Unfortunately, however, its fondness for predaceous beetles must be reckoned against it. It also leads in the consumption of grasshoppers; these and beetles together forming 36 per cent. of its whole food." (Beal.) It also eats a little corn, a good deal of wild and cultivated fruit, and beech-nuts. It does not injure trees by pecking them. The nest is dug out of almost any woody substance, preferably a tree, but frequently a post will do as well.

156. (409.) Centurus carolinus (Linn.). 145. Red-bellied Woodpecker.

Synonyms: Melanerpes carolinus, Picus carolinus.

Zebra Bird, Guinea Woodpecker, Carolina Woodpecker, Checkered Woodpecker, Zebra Woodpecker, Orange Woodpecker or Sapsucker.

Wilson, Am. Orn., I, 1808, 113.

The Red-bellied Woodpecker is fairly common in the 
southern part of the state, but less numerous in the northern part. It is a resident everywhere, nesting in the deeper woods.

In addition to its usual diet of insects and worms it is a lover of ripe apples, and in winter finds acorns and beechnuts good forage. It has been detected in the act of storing away acorns and nuts for winter consumption.

15\%. (412a.) Colaptes auratus luteus Bangs. $14 \%$. Northern Flicker.

Synonyms: Colaptes auratus, Picus auratus Cuculus auratus.

Golden-winged Woodpecker, Flicker, High-holder. For the remainder of the 125 English synonyms see "The Wilson Bulletin," No. 31 , for sale by the author at 25 cents a copy. Kirtland, Ohio Geol. Surv., 1838, 162.

The Flicker is probably strictly migratory in its habits, in spite of the fact that it is resident throughout the statein small numbers in the north, common in the south. It is abundant as a migrant, but hardly more than common during the nesting season. In winter it will eat anything that can be found. In summer it seems to crave ants, of which it consumes quantities. During harvest days it becomes lazy and then feeds on the ground like a Meadowlark, catching the young grasshoppers and crickets and fattening upon them. It must be classed among the distinctly useful birds, both as a destroyer of insects and as an alarm clock if you have been so unwise as to cover any part of your roof with tin! $3: 30$ in spring, $4: 00$ in summer and $4: 30$ in autumn are the hours which he loudly heralds for the beginning of day. You can't drive him away.

The migrating host of Flickers reaches northern Ohio during the third week in March. Its numbers are considerable up to the middle of October, or even the first of November. 
Order MACROCHIRES. Goatsuckers, Swifts, Hummingbirds.

\section{Suborder CAPRIMULGI. Goatsuckers.}

Family CAPRIMULGIDE. Nighthawk and Whippoorwill.

158

(41\%.) Antrostomus vociferus (Wils.). 138.

Whip-poor-will.

Synonyms: Caprimulgus vociferus.

Night-Jar.

Kirtland, Ohio Geol. Surv., 1838, 162, 180.

The Whip-poor-will is decidedly local in its distribution, being common at one place and unknown at another not far away, with no apparent reason. It is strictly nocturnal in habits, and is therefore more often heard than seen. Even when flushed in daylight it flies but a few rods and settles down again, trusting to its protective coloration for concealment. So perfectly does its plumage and posture simulate a part of a log, or a knot on a log, that it is perfectly hidden from all but practiced and discriminating eyes. Being strictly insectivorous it is strictly migratory in habits, reaching southern Ohio during the third week in April and the northern counties shortly after the first of May. It has left the state by September 22 .

In northern Ohio one must look for the Whip-poor-will in the wilder and rougher parts of the region. River gorges and rocky bluffs may harbor numbers of pairs.

159. (420.) Chordeiles virginianus (Gmel.). 139. Nighthawk.

Synonyms: Chordeiles popetue, Caprimulgus virginianus, C. popetue var. popetue.

Bull Bat, Goatsucker, Night Jar, Mosquito-hawk, Pisk. Kirtland, Ohio Geol. Surv., 1838, 162.

Contrary to its name, the Nighthawk is not strictly nocturnal, but is rather a bird of the twilight and dark days, but it is frequently seen at broad day, particularly during the season of southward migration. It is more numerous dur- 
ing twilight, when it may be seen leisurely flitting about in crazy fashion gathering its harvest of flying insects, with an occasional quick dart here or there after some larger and quicker prey. It is strictly migratory, reaching our southern border about the first of May, and the lake shore a week later; departing southward again about the middle of September. It is thus a little later in appearing and a little earlier in leaving than Whip-poor-will.

In northern Ohio, at least, it seems to nest preferably on the tops of our taller city buildings. I have yet to learn of a nest that has been found in the woods within thirty miles of Cleveland.

The Whip-poor-will and Nighthawk take up the destruction of insects where the swallows and flycatchers leave it. We could wish there were more of all kinds of insect eaters, particularly those which feed at night.

\section{Suborder CYPSELI. Swifts.}

\section{Family MICROPODIDÆ. Swifts.}

\section{0. (423.) Chatura pelagica (Linn.). $13 \%$. Chimney Swift.}

Synonyms: Hirundo pelasgia, H. pelagica, Cypsselus pelasgius, Chætura pelasgica.

Chimney Swallow, Common Swift, Swift.

Wilson, Am. Orn., V, 1812, 48.

This familiar bird is pronounced abundant over the entire state. It nests in the smaller chimneys, and roosts in communities in the larger chimneys. I find no records of nesting in hollow trees. Dr. Wheaton speaks of the probability that a few pairs nested in an old hollow tree three miles east of Columbus, prior to 1882 .

The Swifts reach Ohio about the middle of April, and seem to distribute themselves pretty generally at once. $\mathrm{Mi}$ gration dates for the southern and northern counties do not differ materially. They do not leave the vicinity of Oberlin until mid-October, sometimes lingering well into the third week. 
Presumably the Swifts must rest at some time, but when seems a mystery. We see them only on the wing, never perched, unless it be in a chimney near or on the nest. Of course their food consists entirely of flying insects captured while flying. No one ever questioned the usefulness of this strong-winged bird.

Suborder TROCHILI. Hummingbirds.

Family TROCHILID瓜. Hummingbirds.

161. (428.) Trochilus Colubris Linn. 136. Ruby-throated Hummingbird.

Kirtland, Ohio Geol. Surv., 1838, 164.

This is the only Hummingbird which ever visits Ohio. It is common all summer over the entire state, nesting either near dwellings or in the woods as fancy may dictate. The head contains no poison gland, so the thrust of the beak is not poisonous unless the bird has just been feeding upon some plant whose blossom is poisonous,

The Hummingbird is not one of the strongest winged birds, but frequently perches for rest. It has brought to perfection the art of hovering and darting as well as forward flight, but cannot soar. It is a great fighter in its way, easily putting to rout Catbirds, Robins and Blue Jays; not by striking with either wings or beak (its feet are too small and weak to be used in that way), but by hovering and dancing close to the bird which it chooses to put to flight. The buzzing, jiggling movement seems to confuse its adversary.

The Hummer reaches our southern border about the first of May, but is a week later at the lake shore. It leaves the state about the middle of September, often tarrying a little longer at the south.

Probably no bird could long live upon a diet of honey alone. It must certainly be true that the Hummingbird eats honey, because its tongue is made that way, but it is just as true that it eats insects which it finds in the blossoms with the honey. It is therefore a useful bird as well as a pleasing feature of our flower gardens. 


\section{Order PASSERES. Perching Birds.}

Suborder ClAMATORES. Songless Perching Birds.

Family TYRANNIDÆ. Tyrant Flycatchers.

The birds which belong to this family are preëminently flycatchers, but while they feed so largely upon flying insects, catching them in mid-air by a sally from some position where they have been waiting, they also eat wild fruits in their season to some extent. Sometimes they descend to the ground to pick up insects seen there. The only member of the family about which complaints have been made is the Kingbird. He is fond of honey bees, and will sometimes nearly destroy a hive if not interrupted in his feast. As a group the flycatchers are among our most useful insect destroyers, supplementing the work of the swallows and Nighthawk, Whip-poor-will, and Chimney Swift.

162. (444.) Tyrannus tyrannus (Linn.). $12 \%$. Kingbird.

Synonyms: Tyrannus carolinensis, T. intrepidus, Muscicapa tyrannus, Lanius tyrannus.

Bee Martin, Bee Bird, Tyrant Flycatcher, Tyrant.

Kirtland, Ohio Geol. Surv., 1838, 163.

The Kingbird is well known to all. It is common during the summer in all parts of the state. While it may be harmful in some individual cases to bee raisers, it is a decidedly useful bird in general.

The Kingbird reaches the Ohio river about April 20, and Lake Erie five days later. It remains only until the first week in September.

163. (452.) MYIARChuS CRINITUS (Linn.). 128. Crested Flycatcher.

Synonyms: Musicapa crinita, Tyrannus crinitus.

Great Crested Flycatcher.

Kirtland, Ohio Geol. Surv., 1838, 163.

This bird is almost as well known as the Kingbird, from which it may be easily distinguished by the reddish instead 
of white-tipped tail. It has taken a notion to the orchards, frequently nesting in the hollow apple trees, in spite of the English Sparrow.

Its arrival follows that of Kingbird within five days, both in the south and north. It generally lingers longer in autumn, not infrequently tarrying until mid-October at Oberlin.

164. (456.) SAyoRnis PHabe (Lath.). 129. Phœbe.

Synonyms: Sayornis fuscus, Muscicapa fuscus, Tyrannus fuscus. Pewee, Pewit, Bridge Pewee, Water Pewee, Pewit Fly. catcher, Phœbe Bird, Barn Pewee, House Pewee.

Kirtland, Ohio Geol. Surv., 1838, 163.

The Phœbe is almost a household bird in many parts of the state, nesting in barns and out-buildings. It also selects bridges, but still clings to its ancient nesting places when possible. Almost any rocky bluff furnishes a home for one or more pairs of Phœbes, whether a river gorge, a deserted quarry, or a natural rock face.

While a true flycatcher it is one of the early spring birds, not infrequently announcing its arrival before the 20th of March at the lake shore. It rarely departs for the south before the leaves have fallen from the trees, which is late October.

During the cold, snowy days of late March I have found Phobe in the deep woods gleaning from the blossoms of the witch-hazel, or apparently eating the buds from a linden tree.

165. (459.) Nuttalornis borealis (Swains.). 130. Olive-sided Flycatcher.

Synonyms: Sayornis borealis, Tyrannus borealis. Wheaton, Ohio Agri. Report, 1860, 1861; 379, 480.

I find no records for this flycatcher east of Clarke county. While Dr. Wheaton throws some doubt upon the admissibility of the records upon which he gave the species a place in his catalogue, except Dr. Langdon's statement for 187\%, 
there can be no reasonable question that it is a rare migrant in the western third of the state.

166. (461.) Contopus virens (Linn.). 131. Wood Pewee.

Synonyms: Muscicapa virens, Tyrannus virens.

Pewee, Pewee Flycatcher.

Kirtland, Ohio Geol. Surv., 1838, 163.

Wood Pewee is more than common. In northern Ohio it is easily the most numerous of any of our flycatchers, because found everywhere where there are trees, except in the deep woods, and where found it is too numerous to escape the notice of the most inattentive. Its plaintive call must be familiar to every one. It is probably less numerous in the more hilly south-eastern parts of the state.

Wood Pewee is among the later arrivals from the south, rarely appearing in the southern counties before May 5th, and in the north not seldom as late as the 10th. It remains with us in Lorain county until the middle of September, but tarries until October along our southern border.

16\%. (463.) Empidonax Flaviventris Baird. 132. Yellow-bellied Flycatcher.

Synonyms: Tyrannula flaviventris.

Kirkpatrick, Ohio Farmer, IX, 1860, 139.

Dr. Wheaton speaks of this species as "A common spring and fall migrant," apparently meaning over the entire state. I have never found it in Lorain county, although it has been taken there. It is not well known if a common migrant. Probably it has greatly decreased in numbers since Dr. Wheaton laid down his work. I find no records of its breeding within the state.

Dr. Wheaton states that this flycatcher is different in habits from the other small flycatchers, in that it frequents fence-rows and is timid, darting into a thicket and remaining hidden when one approaches. This may account for its apparent scarcity. 
168. (465.) Empidonax virescens (Vieill.). 133. Green-crested Flycatcher.

Synonyms: Empidonax acadicus, Tyrannus acadicus, Platyrhinchos virescens.

Acadian Flycatcher, Small Green-crested Flycatcher. Kirtland, Ohio Geol. Surv., 1838, 163.

Apparently more pairs of this woods haunting flycatcher nest in the northen half of the state than in the southern half. It is fairly common everywhere, but may almost be called abundant in the heavier woods in the north. Its small size and weak voice cause it to be overlooked by many who should know it.

In its northward migration it reaches the lake shore about the first of May, and does not return south before the second week in September.

169. (466.) Empidonax trailli (Aud.). 134. Traill Flycatcher.

Synonyms: Empidonax pusillus traillii, Tyrannus traillil, Muscicapa traillii.

Little Flycatcher.

Read, Fam. Visitor, III, 1853, 359.

This is another little known species, probably rather because it is so difficult to distinguish between the small flycatchers unless one knows the song, than because the bird is rare. As a migrant it seems to be fairly common in most counties, but only a few remain to breed in the southern tier of counties. I found it breeding in considerable numbers at Licking reservoir and at Lewiston reservoir. It prefers a willow or alder fringed lake or marsh for its summer home. A short distance from such places it may not be found at all.

This is one of the last of the migratory birds to appear; sometimes not reaching northern Ohio before the middle of May, rarely before the 10 th day. It is gone again by the first of September. 
170. (46\%) Empidonax minimus Baird. 135. Least Flycatcher.

Synonyms: Tyrannus acadicus, Tyrannula minima. Chebec, Sewick.

Read, Family Visitor, III, 1853, 359.

While this is common as a migrant throughout the state it appears to be rare as a summer resident, especially in the south. I have yet to find a pair breeding in Lorain county. It is, however, given as breeding in Erie county, and as possibly breeding in Scioto county by Rev. W. F. Henninger. It seems likely that it is local in its summer distribution. In August we found it along the Ohio river from Marietta to Ironton.

The Least Flycatcher reaches Lorain county by the 25th of April and departs about the first of September.

\section{Suborder OSCINES. Song Birds.}

\section{Family ALAUDID压. Larks.}

The true larks are found in flocks of from a few to several hundred individuals except during the breeding season. Their food consists of weed seeds and such grains as may be scattered in the fields or by the roadside, and the eggs and larvæ of insects. Probably adult insects are also eaten to some extent. They are useful birds.

171. (474.) Otocoris Alpestris (Linn.). 126. Horned Lark.

Synonyms: Eremophila alpestris, E. cornuta, Alauda alpestris. Shore Lark. Kirtland, Ohio Geol. Surv., 1838, 164, 183.

It is unfortunate that so few persons are able to distinguish certainly between our three forms of Otocoris. The evidence seems to be pretty clear that there has been a shifting about of alpestris and an invasion of praticola since Dr. Wheaton wrote in 1882. He was familiar with the winter bird but knew nothing of the summer form, which he would have known had it been as common as it is now. 
"Abundant winter resident" is the term he applies to alpestris, the form known to him. After an experience of twelve years in Lorain county. I would not consider it more than common. In 1882 it apparently ranged completely across the state, but now there are no extreme southern records. This, again, may be due to unfamiliarity with the birds. At any rate it is more common north than south. I have seldom seen true Horned Larks before the first considerable cold wave which brings snow. This may be late in November or not until the second week in January. Most of the Horned Larks have gone north by the middle of March, but individuals sometimes tarry until early May.

During the winter the Horned Lark is largely a seed eater, and destroys quantities of noxious weeds in embryo. During the period of snow covered landscape he searches out the freshly spread manure, or goes into the pastures where fodder has been scattered, picking up what the cattle have left or uncovered. Flocks of several hundred are not uncommon at such times.

\section{2. (474b.) Otocoris alpestris praticola Hensh. - Prairie Horned Lark.}

Dwight, Auk, VII, 1890, 145.

This is the first specific reference. In a general way Henshaw covered Ohio in his review in 1884 , but made no specific reference to Ohio. This form was not elaborated until two years after Dr. Wheaton had seen his catalogue out of the press, but since he makes no mention of the breeding of the Horned Lark it seems likely that he did not know this form. It is very probable that it invaded the state just after Dr. Wheaton laid down his work.

0 . a. praticola is now the common resident form nearly throughout the state. It is naturally more numerous in the more level northern and western parts than in the rougher south-eastern. Naturally it is confused with alpestris bymany of the Ohio men, particularly those who are familiar with the earlier classification which Dr. Wheaton used.

In general habits this form agrees with alpestris. During 
the summer, particularly the breeding season, the regular diet of weed seeds is supplemented with insect larvæ.

Since these birds may usually be rather closely approached during the winter when they associate together, and always head into the wind, they may be readily distinguished by the yellow line above the eye in the true Horned Lark, and by the white line, with no trace of yellow, in Prairie Horned Lark. Both have yellow or yellowish throats, Horned Lark the brighter and clearer. The form hoyti is as large as alpestris, but is lighter than praticola, and with no yellow over the eye. -

173. (474k.) Otocoris Alpestris hoyti Bishop. -
Hoyt Horned Lark.

Synonyms: Otocoris alpestris leucolema.

Oberholser, A Review of the Larks of the Genus Otocoris, Proceedings of the U. S. National Museum, XXIV, No. 1271, 812.

The specimen above referred to, captured at Wooster, one in the Oberlin College collection, and at least three in the collection of the Ohio State University, are all of which I have any record. A critical examination of local collections may reveal others. The recent elaboration of this subspecies makes it impossible to say what its status in our state is. From the small amount of evidence I would infer that it is a winter visitor with the Horned Lark, ranging into the state from the north-west.

Family CoRvide. Crows, Jays, Magpies, etc.

The food habits of the three representatives of this family which occur in Ohio are given under the species.

174. (47\%.) Cyanocitta cristata (Linn.). 125 Blue Jay.

Synonyms: Cyanurus cristatus, Cyanura cristata, Corvus cris. tatus, Garrulus cristatus.

Jay Bird.

Kirtland, Ohio Geol. Surv., 1838, 162.

Blue Jay is a familiar and common resident throughout the state except in the south-eastern portion. He is usually 
more in evidence during the winter than during the summer, no doubt because he finds food more plentiful and more easily obtained in towns and cities. During the winter the jay is a great scavenger, visiting the kitchen waste barrel regularly. He will eat almost anything that can be digested, and sometimes other things as well. Corn and nuts furnish a good share of his winter food, where they are plentiful. His friends keep still about what he eats during the summer. There is no doubt that many nests despoiled of eggs or even young must be laid to his mischievous propensities. One might be allowed to judge of his character by the manner in which his neighbors receive him. The appearance of a jay in any neighborhood is the signal for all the birds to band together to drive him away. Prof. F. E. L. Beal's examination of 292 stomachs failed to sustain the almost universal testimony of the robbing proclivities of this bird. There was some evidence of it but too little upon which to base a sweeping condemnation. On the other hand, the Blue Jay certainly does destroy large numbers of injurious insects.

While it is probably true that the Blue Jay is migratory to some extent, the northernmost birds receding south a greater or less distance to spend the winter, and the others also crowding south to give place to them, it is not an appreciable movement in Ohio.

\section{5. (486a.) CoRvus CORAX PRINCIPAlis Ridgw. 123. Northern Raven.}

Synonyms: Corvus corax, C. corax var. carnivorous, C. carnivorus.

Raven, American Raven.

Wilson, Am. Orn., IX, 1825, 136.

The records seem to indicate that in Wilson's time the Raven was so common along the lake shore, particularly easterly, as to entirely supplant the Crow. It gradually decreased in numbers, until none were known except in the extreme northwest. In $1882 \mathrm{Dr}$. Wheaton regarded it as a "Rare winter visitor." Mr. Thos. Mikesell, of Wauseon, 
is the only person who reports its occurrence at the present time. Other residents of Fulton county corroborate $\mathrm{Mr}$. Mikesell's statement. Apparently it has been in the habit of nesting in that corner of the state and in the adjoining parts of Indiana. Doubtless the next decade will witness its complete extinction from the state.

176. (488.) Corvus americanus Aud. 124. American Crow.

Synonyms: Corvus frugivorus, C. corone.

Crow, Common Crow.

Kirtland, Ohio Geol. Surv., 1838, 162.

Our common Crow is resident in some numbers in the southern portion of the state, and may be found in small numbers in favorable places even to the lake shore. Cold, snowy winters are likely to drive most if not a 2 dividuals south at least to the center of the state. The northward movement of the Crow host reaches Lorain county early in March, but it is almost wholly dependent upon weather conditions. Not infrequently small companies of these birds may be seen moving north during the last week of February. Considerable numbers remain well into December in all but exceptionally cold winters which begin early.

It is well known that the Crow is a social bird to an unusual degree, except when nesting. Crow "Roosts" are readily located by noting the converging lines of flight during the afternoon in spring and fall, and in winter in the southern counties.

It would be superfluous to discuss the food habits of this interesting bird here. The reader can obtain an exhaustive paper upon the Crow by writing to the Secretary of Agriculture, Washington, D. C. The evidence which will be found there is slightly favorable to the Crow. But it must be admitted that during planting time he is a mischievous bird, and then may deserve a warm reception. But that he does eat many insects which destroy quantities of grain must also be freely admitted. 
Family Icteride. Blackbirds, Orioles, Meadowlarks, etc.

Most members of this family are among the best known of our birds, because they either live about dwellings or in our parks, or because they are conspicuous in either color or voice. Their food habits are discussed in detail under each species.

17\%. (494.) Dolichonyx oryzivorus (Linn.). 114. Bobolink.

Synonyms: Icterus agripennis, Fringula oryzivorus.

Reedbird, Ricebird, White-winged Blackbird, Skunk Blackbird, Bob Lincoln, Butterbird, Ortolan, Meadow-wink, Maybird.

Nuttall, Manual, I, 1832, 185.

In his full wedding dress the Bobolink is a well-known bird, but in his traveling suit of drab and yellow he is to most persons a common sparrow. I was somewhat surprised to learn that while the Bobolink is one of our most familiar meadow inhabitants in northern Ohio, it is not found at all during the summer in the southern part, only passing through as a migrant twice a year. I found it breding sparingly at both the Licking and Lewiston reservoirs. It is reported as common all summer as far south as Delaware, but apparently at the Licking reservoir it is near its southern breeding limit.

Being a meadow haunting bird, its appearance in the state must have followed the disappearance of the forests, except in the more open north-western counties. Dr. Wheaton places its first appearance in Geauga county in $185 \%$.

Bobolink reaches Lorain county during the last week of April. The males change their garb during July and early August, after which the species may be found in flocks of varying size, making ready for their journey to the Florida rice fields. They are gone by the middle of September. In the southern part of the state they remain but about a week after their first appearance in spring, and return again during the second week in September, to remain but a few days. 
With us the Bobolink is both interesting and useful. His irresistible burst of song is one of our treasures, and his destruction of insects and weed seeds makes him an aid to the farmer. But in the south he has found the rice fields a never failing source of food, and often pays the penalty of thieving with his life. The year through he is more useful than harmful.

178. (495.) Molothrus Ater (Bodd.). 115.

Cowbird.

Synonyms: Icterus pecoris, Molothrus pecoris, Fringilla pecoris. Cowbird, Cow Blackbird, Cow Troupial, Cow Bunting, Common Cowbird, Chuckold, Blackbird, Shinyeye, Lazy Bird, Clodhopper, Buffalo Bird.

Kirtland, Ohio Geol. Surv., 1838, 162, 180.

It is hard to find anything good to say about this lazy tramp. He is, unfortunately, common all summer over the entire state, so that nowhere can the other birds find refuge from his depredations. We may have small pity for the stupidity of the other birds in permitting the alien egg to remain in their nests to work the destruction of their own young, but how different are we when we find a poor human waif which somebody may be too lazy to care for? Some birds, particularly the larger ones, do throw the egg out of their nest, but few of the smaller ones seem to make any effort to free themselves of the incubus. The presence of a young Cowbird in the nest of a species which is smaller than the Cowbird, frequently results in the death of the rightful inhabitants of the nest, and so great damage is done in the destruction of really beneficial birds.

There are perhaps two good things about the Cowbird. It eats the insects and grubs which are more or less injurious to cattle, and which are found in the pastures among the herds, and its flesh is good to eat! Cowbird and English Sparrow should find their way to the bill of fare of our hotels. They are dainty tidbits. Call them Ricebirds if you prefer.

The Cowbird reaches Ohio during the middle of March and returns south late in October. It frequently associates 
with the Bronzed Grackles in their roosts during the summer and autumn, and may sometimes be found in the northward moving flocks made up of the several species of "Blackbirds." During the summer it is found in companies of five to eight individuals, both males and females, about the woodlands and pastures.

179. (498.) Agelaius phaniceus (Linn.). $11 \%$. Red-winged Blackbird.

Synonyms: Agelæus phœnicus, Icterus phœnicus, Oriolus phœniceus.

Swamp Blackbird, Red-winged Starling, Red-and-buff-shouldered Marsh Blackbird, Blackbird.

Kirtland, Ohio Geol. Surv., 1838, 162.

This is probably the most familiar bird of the swamps and marshes in all parts of the state, where it nests in large numbers. In some regions where its natural nesting places of rushes and cat-tails have disappeared on account of drainage, it has gone into the clover fields and meadows. In others it has taken to the brush.

The testimony of the examination of large numbers of stomachs of this bird shows that it may prove harmful in some places and under some circumstances, but that its harmfulness is about one-eighth, as represented by the grains which it eats. The harmful insects and weed seeds which it destroys should far outweigh any damage done to agriculture. No doubt a large part of the grain eaten is waste grain.

The Red-wing is one of spring's harbingers. He reaches Ohio not far from the first of March, but is inclined to be a few days later than the Bluebird and Robin. When the season is late he may come in a large flock of "Blackbirds," but earlier he seems to prefer to travel with a small company of his own kind only. Like the other birds of his color he loves company, and after the young are able to fly, a whole swamp full select a place to spend the nights, which may be with the other species, or possibly a roosting-place exclusively of his own species. The most of our Red-wings 
have gone south by the last of October, but a few remain well toward December, especially in the southern counties.

180. (498a.) Agelaius pheniceus fortis Ridgway. Thick-billed Red-wing.

There is a specimen in the Oberlin College collection which seems clearly to belong to this new race. It was taken October 25, 1890, by C. A. Kofoid, at Oberlin. Apparently this form should be found among the early spring and late autumn Red-wings. The form has been so recently elaborated that it has not been possible to examine specimens in the different collections.

181. (501.) Sturnella magna (Linn.). 118. Meadowlark.

Synonyms: Sturnus ludovicianus, Sturnella ludoviciana, Alauda magna.

Fieldlark, Old Fieldlark, Meadow Starling, Marsh Quail. Kirtland, Ohio Geol. Surv., 1838, 162.

Like the Crow, Meadowlark may remain in small numbers in the northern part of the state all winter. Long continued cold, and particularly snow, will usually drive all south, or into some region not covered by snow. In the southern counties, decreasingly northward, it is a regular winter resident. No doubt the present condition of the Meadowlark is due to the clearing away of the forests, but unlike the Bobolink, it does not require so extensive fields and therefore probably found natural clearings in the forests possible breeding grounds before the appearance of the white settlers. If so his numbers were far less than now.

There should be no note of condemnation for this bird. His services in the meadow and fields cannot be estimated in values. Even during the winter insects comprise a large proportion of his food, while practically no grain that could be saved is eaten at any time. To say that 73 per cent. of the whole amount eaten is insects, a large part of which eat grains, is telling but half of the story. Being a ground haunter, the insects destroyed are such as the other birds 
do not touch. It is therefore one of the birds which should be rigidly protected.

182. (506.) ICterus SPURIUS (Linn.). 119.

Orchard Oriole.

Synonyms: Oriolus spurius.

Kirtland, Ohio Geol. Surv., 1838, 162.

The Orchard Oriole is a fairly common summer resident throughout the state. In Lorain county it has increased, during the last ten years, from scarcely more than casual to fairly common. Writing in 1882 , Dr. Wheaton states that in the vicinity of Columbus, at least, it resorts to "the low banks of sparsely wooded streams and willow thickets," preferring such places to orchards. In Lorain county it is more often found in orchards than elsewhere.

The birds are not numerous enough to figure economically, but if they were their food would be found to consist largely of insects injurious to fruit. The birds probably eat some ripe fruit in its season, but so little of it as to be of no consequence. Ripe mulberries are eaten with a good deal of relish.

The Orchard Oriole reaches our southern border during the last week in April and spends nearly a week in traversing the state, seldom appearing at Oberlin before the first of May. Its departure southward is a little uncertain, but seems to be about the middle of August.

183. (50\%) Icterus galbula (Linn.). 120. Baltimore Oriole.

Synonyms: Icterus baltimore, Oriolus baltimore, Coracias galbula.

Golden Robin, Hangnest, Firebird, Peabird, Hanging-bird. Kirtland, Ohio Geol. Surv., 1838, 162.

This is the common Oriole throughout the state, and is apparently on the increase in most sections. It is one of the first birds which the would-be bird student sees and hears, because it comes into the door-yard to nest, and sings fear- 
lessly. Its pendant nest is a familiar sight on almost every street, after the leaves have fallen.

Its food consists largely of injurious insects, particularly caterpillars and the small plant and bark lice which are overlooked by most other birds. It is true that some ripe fruit is eaten, but so little, usually, that little harm is done. A mulberry tree will prove a safeguard from anything which the Baltimore Oriole might be inclined to do with other fruit, for he does love ripe mulberries.

This Oriole reaches our southern border early in the last week of April, and loses little time in crossing the state, passing south about September 5, in the northern, and the 10 th in the southern counties. A few individuals may linger well toward October.

184. (509.) Scolecophagus Carolinus (Müll.). 121. Rusty Blackbird.

Synonyms: Scolecophagus ferrugineus, Quicalus ferrugineus, Oriolus ferrugineus, Turdus carolinus.

Rusty Grackle, Thrush Blackbird.

Kirtland, Ohio Geol. Surv., 1838, 162.

The little known Rusty Blackbird is a regular migrant across the state both spring and autumn, usually fairly common but seldom, if ever, very prominent. In the southern counties it is a tolerably common winter resident. As a migrant it could do no harm if it would, except possibly to the ripe corn crop. There is no evidence that it is ever harmful.

It is among the earlier spring birds, arriving during the first week in March and remaining until the end of the first week in May, returning again about the middle of September and remaining well into November, in the north. There is one record for February 13, 1897, when a female was shot in the marshes on Lake Erie. It must have wintered there. 
185. (511b.) Quiscalus Quiscula eneUs (Ridgw.). 122. Bronzed Grackle.

Synonyms: Quiscalus purpureus var. æneus, Q. versicolor, $Q$. purpureus, Q. æneus.

Crow Blackbird, Common Blackbird, Purple Grackle, Bronzed Crow Blackbird, Brass Grackle, Western Crow Blackbird.

Kirtland, Ohio Geol. Surv., 1838, 162, 180.

This is the common "Blackbird" of lawns and shade trees. Its steel-blue head and neck and bronze-colored body would at once distinguish it from the other blackbirds. Dr. Wheaton states that it is "Found everywhere, but is especially numerous in sycamore groves along streams, and in oak woodland." I am not aware that it is now found breeding away from the immediate vicinity of human habitations. It is particularly numerous at farm dwellings where Lombardy poplars are numerous, and in towns and parks among the evergreen trees. It also roosts in the shade trees in parks and along the streets where shade trees form a sufficiently thick growth.

There can be no question that this species does more good than harm the whole year through, but that is not saying that the birds should always be left to do as they choose. It is too true that during the fall, when the small grains are standing in shock and the corn is in the milk, the grackles do great damage, sometimes descending in immense flocks upon a field, filling themselves with the grain. They also eat ripe fruit to some extent. During the spring they are decidedly beneficial in ridding the newly turned soil of grubs and other insect larvæ. The farmer must be his own judge and execute his sentence-if he can.

The Bronzed Grackles reach northern Ohio during the first week in March, not seldom with the other first spring birds. At Oberlin the arrivals usually fly first to the trees in which the roost was selected the previous summer, and then station themselves about town to suit their own fancy. The bulk of individuals leave for the, south about November 10 , but stragglers remain into December, or rarely all winter long. 
Family FRINGILLIDÆ. Finches, Sparrows, Buntings, etc.

Of this group there have been found in Ohio 33 species native to North America, and one imported species. Only one other family of birds exceeds this in number of species, and probably none exceeds it in the numbers of individual birds, for the sparrows are always numerous. These birds are also among the most puzzling to the average student. Their food habits are given under each species.

\section{6. (514.) Hesperiphona vespertina (Coop.). 84. Evening Grosbeak.}

Synonyms: Coccothraustes vespertina, Fringilla vespertina. Kirtland, Ohio Farmer (newspaper), IX, 1860, 91.

Dr. Wheaton knew of but one record for this northern species, in the reference given above. A female was taken by Mr. Charles Pease, Jr., and several others were seen by Dr. Kirtland, a few days previous to March 24, 1860. There was a small flight southward during the latter part of January, 1890, when a specimen was secured by Dr. Carl Tutthe, of Berlin Heights, Erie county, January 30, 1890; a number were seen by Mr. A. Hall, of Cleveland, and by Rev. J. M. Keck, in Lake county. At best it is a rare winter visitor to northern Ohio.

18\%. (515.) Pinicola enucleator leucura (Müll.). 85 Canadian Pine Grosbeak.

Synonyms: Pinicola enucleator, Corythus enucleator, Pinicola canadensis, Loxia enucleator.

Kirtland, Am. Journal Sci. and Arts, XIII, 1852, 218.

The records 'of the occurrence of this northern bird are few, and, except Audubon's inferential reference to specimens captured at the mouth of the Big Guyyandotte, in West Virginia, are confined to northern Ohio. Dr. Wheaton gives three records, two besides Audubon's. Dr. Kirtland recorded it from near Cleveland, and the statement by $\mathrm{Mr}$. Rea'd that it is "rare, though occasionally seen during most of the year," seems to me a decidedly questionable 
record. Possibly the Purple Finch was meant. The only other records that I have are one by Mr. A. Hall, of Cleveland, who captured a specimen, date not known, and one by myself in Lorain county, January 1,1902 . It seems likely that more activity in field work during the winter would result in other records of this interesting species.

188. (51\%.) Carpodacus purpureus (Gmel.). 86. Purple Finch.

Synonyms: Fringilla purpurea.

Purple Grosbeak, Crimson Finch, Linnet.

Kirtland, Ohio Geol. Surv., 1838, 164, 184.

The Purple Finch is a regular, but hardly common, migrant, and less numerous winter resident in all parts of the state. With us it occurs in small flocks, frequently associated with Goldfinch. In Lorain county it is too irregular to make any definite statements about its appearance in spring or autumn worth anything. Singing individuals have been recorded after the middle of May, and as early as the first of September.

While in the state the food of this species is not such as to affect agricultural interests, if it ever does. I have seen it breaking off and scattering the buds from trees, working at the pine cones, and eating weed seeds from near the ground.

189. (521.) Loxia curvirostra Minor (Brehm.). $8 \%$. American Crossbill.

Synonyms: Loxia curvirostra var. americana, L. curvirostra, Curvirostra americana, Curvirostra minor.

Common Crossbill, American Red Crossbill, Red Crossbill. Kirtland, Ohio Geol. Surv., 1838, 164, 184.

This Crossbill is an irregular winter visitor, and possibly breeds occasionally. Its appearance and disappearance are unaccountable. It has appeared at Oberlin during early autumn and been common both in the village and surrounding region until the following June, and then disappeared completely for months or years. Considerable flights some- 
times occur during the winter or early spring only, followed abruptly by total disappearance. It may be found anywhere in the state where coniferous trees furnish food. Mr. E. A. Doolittle informs me that flocks are present now (late June) at Painesville. I have found a flock at Oberlin during the last week in June, 1903.

I have never seen the birds feeding on anything but pine nuts which are taken from the cones either on the trees or as they lie on the ground.

\section{0. (522.) Loxia LeUCoptera Gmel. 88. White-winged Crossbill.}

Synonyms: Curvirostra leucoptera.

Wheaton, Ohio Agri. Report, 1860, 346, 366.

This Crossbill is rare in Ohio. There appear to have been three flights, of which we have records, which may have reached Ohio. One was in 1868-9, when Dr. Langdon found considerable numbers of them associated with the Red Crossbills in the proportion of two of the Whitewinged to one of the other, in the vicinity of Cincinnati. Another flight mentioned by Mr. A. W. Butler (Birds of Indiana, 921) occurred in 1883-4, when numerous Indiana records were made, but apparently no Ohio records have come to light for this flight. The third and last occurred during the winter of 1901-2, when a flock remained near Flyria, Lorain county, for at least two weeks early in January, 1902. Other records are scattering and probably do rot have to do with large flights. At best the species is irregular, requiring unusual weather and food conditions to be forced south.

191.

(528.) Acanthis linaria (Linn.). 89. Redpoll.

Synonyms: Egiothus linaria, Fringilla linaria. Red-poll Linnet, Common Red-poll, Lesser Red-poll. Kirtland, Ohio Geol. Surv., 1838, 164, 183.

The Redpoll is probably a little less rare, than the last 
species, but it has ceased to be the "Tolerably regalar winter resident in northern Ohio" that Dr. Wheaton knew. During my ten years' residence in Oberlin I have never seen it, in spite of many winter days spent afield in search for it. The "rare oecasions "when it does cross Lake Erie are notable ones, for then the birds are among the most numerous of winter birds. Stragglers may be found occasionally. One was taken by Mr. Charles Dury in January, 1869, at Cincinnati.

The Redpoll feeds much after the fashion of the Goldfinch, the flock taking possession of a weed and apparently cleaning out the seeds before leaving, twittering all the while. They are not wary and allow a close approach.

192

(529.) Astragalinus tristis (Linn.). 90. American Goldfinch.

Synonyms: Chrysomitris tristis, Fringilla tristis, Carduelis tristis, Spinus tristis.

Yellow-bird, Thistle-bird, Lettuce-bird, Salad-bird, Wild Canary.

Audubon, Orn. Biog., 1831, 172.

Goldfinch is one of our commoner birds the year through, but during the colder part of the year-from October to April-he is known as a common sparrow, by the majority of persons, because his bright yellow and deep black dress has given place to drab only tinted with yellow. He has lost his cheerful, rollicking song, also, substituting a conversational twitter while he feeds or flies. During the more inclement weather flocks of Goldfinches take refuge in the woods, where they feed upon such weed and grass seeds as may be found there in the more open places. At other times they range the fields for food. Goldfinches and Tree Sparrows are frequently found in flocks together, both in woods and open fields.

The winter food of Goldfinch consists largely of weed and grass seeds taken from standing weeds and grass. In summer and autumn thistle seeds are much in favor, as they are in winter if there are any left. Insects are 
eaten and fed to the young during July and August, with some seeds after the young are able to digest such hard food. The great usefulness in destroying quantities of weed seeds cannot be questioned. If he ever does damage I have not heard of it.

193. (533.) Spinus pinus (Wils.). 91.

Pine Siskin.

Synonyms: Chrysomitris plnus, Fringilla pinea, Linaria pinus. Pine Linnet, Pine Finch American Siskin.

Storer, Proc. Bost. Soc. Nat. Hist., II, 1845, 52.

The Pine Siskin has certainly decreased in numbers since Dr. Wheaton knew it in 1882 , when he regarded it as abundant. It is reported as rare from the southern, and only locally common from the central portion of the state. In the northern counties, particularly those touching Lake Erie, it may frequently become common during the autumn and spring, less so during winter. There is no authentic record of its breeding in the state, unless Dr. Kirtland's circumstantial evidence of mating and presence in June and July, 1850 , be so considered. He states that both old and young appeared for three successive years early in July. No nests were found.

I have never found the Pine Siskin before the first week in September nor later than the first week in May in Lorain county. It is not always present all winter, but may be. I have found it usually associated with Goldfinch feeding with them and like them, but occasionally in small flocks by themselves feeding in the pine and cedar trees and hemlocks.

194. (534.) Passerina nivalis (Linn.). 92. Snowflake.

Synonyms: Plectrophanes nivalis, Emberiza nivalis, Plectrophenax nivalis.

Snow Bunting, Snowbird, White Snowbird. Audubon, Orn. Biog., II, 1834, 515.

Snowflake seldom appears in northern Ohio before the 
new year opens. It could hardly be called common, in the usual acceptance of that term, at any time, because the birds band themselves together in greater or lesser flocks and are not found in any other fashion. The flocks range over considerable territory, appearing and reappearing at any one place but few times during the winter. The flocks may range from a few to several hundred individuals. Rarely single birds may be found with the flocks of Horned Larks or Lapland Longspurs. The species is less and less numerous as one proceeds southward from the lake shore, becom ing only occasional in southern Ohio, in exceptional weather.

Feeding wholly on the ground, Snowflake picks up such seeds as may have been dropped or missed by the other sparrows. When the ground is completely covered with snow they are driven to feed upon the standing weed tops which project above the snow. A favorite feeding-place is a railroad track, where grains of wheat and oats sift through the cars and afford easy picking.

The Snowflakes are strictly winter birds, seldom appearing before the country is well snow-bound, or they drive down just in front of a blizzard to give fair warning. They are gone before April, usually not long after the first of March.

\section{5. (536.) Calcarius lapponicus (Linn.). 93. Lapland Longspur.}

Synonyms: Plectrophanes lapponicus, Centrophanes lapponicus, Fringilla lapponica.

Wheaton, Ohio Agri. Report, 1860, 366.

Dr. Wheaton's statements regarding this winter species still hold good for practically all of the state, except that I would not term it common at any time. "The first to appear are single birds, in company with Shore Larks. Afterward they may be seen in compact flocks of from ten to thirty, frequenting old brick-yards, and fields where cattle are fed, in company with Shore Larks, with which they associate on the ground, but fly by themselves in close flocks. 
Frequently when first flushed they utter a rapid rattling note." To this we can fully agree.

The first severe winter weather marks their appearance, which is about the first of December, in the vicinity of Oberlin. I have seen flocks as late as April 23.

The food is chiefly weed and grass seed and grain, with a little insect food intermingled, even in winter. The birds are strictly beneficial.

\section{6. (540.) Pocectes gramineus (Gmel.). 95. Vesper Sparrow.}

Synonyms: Pœcætes gramineus, Fringilla graminea.

Bay-winged Bunting, Grass Finch, Gray-bird, Vesper-bird, Ground-bird.

Kirtland, Ohio Geol. Surv., 1838, 164.

This is our common "Ground Sparrow" so called. It does not disdain a perch on a fence, nor even a tree, but is more often found skulking or running on the ground in the grass. The first part of its song is a weak imitation of Meadowlark's usual song. The bird may be readily recognized by its two white outer tail feathers.

The food of the Vesper Sparrow varies with the season. While it remains in the state it eats more insects than vegetable matter, but during the winter it eats seeds and grain almost exclusively. During the warmer part of the summer its diet is 90 per cent. insect. A large part of the grain eaten is undoubtedly gleaned from the stubble, and would be wasted if the sparrow did not find it, or spring up in next year's cornfield only to make trouble. The good done in the destruction of injurious insects is greater than that of any other sparrow. Add to this the weed seeds destroyed during the autumn and you have a strong case for this sparrow.

Vesper Sparrow reaches Oberlin during the last week in March, and is common on the day of arrival, singing lustily. In a few days the numbers have greatly increased until almost every other bird seen is of this species. They literally swarm over the fields and pastures. As the migrations progress the numbers are reduced somewhat, but all 
summer long it is an abundant species. The bulk of individuals has gone south by the first of October, but scattering individuals may remain well into November.

\section{7. (542a.) Passerculus sandwichensis savanna (Wils.). 94. \\ Savanna Sparrow.}

Synonyms: Passerculus savanna, Ammodramus sandwichensis savanna, Fringilla savanna.

Common Savanna Sparrow.

Wheaton, Ohio Agri. Report, 1860, 366 .

Judging from the reports that have come to me, this is not a common species, certainly not "Very common," as Dr. Wheaton found it. The apparent rarity may well be due to unfamiliarity. I have not found it even common in Lorain county; a half-dozen records for the season is unusually good success. I have utterly failed to find this bird in summer. Rev. Mr. Henninger reports it as common during the migrations, but a rare breeder in southern Ohio (Scioto and Pike counties). In the nature of the case, it must be of local distribution. It is a great skulker in the grass and may easily escape notice.

This, with other sparrows of the genus, prefers insects to seeds and grain, while they are with us. This sparrow in particular is the greatest of all beetle-eaters. Weevils and other destructive species form a large part of its diet during June, July, and August. The seeds eaten are weed seeds that we are anxious to get rid of, and the grain is almost wholly waste, since these birds do not go in flocks, but skulk about rather than expose themselves to view.

The Savanna Sparrow appears in southern Ohio during the first week in April, and has reached our northern counties a week later (March 21, 1903). It leaves us about the last week in October. 
198. (546.) Coturniculus Savannarum passerinus (Wils.). 96.

Grasshopper Sparrow.

Synonyms: Coturniculus passerinus, Ammodramus savannarum passerinus, Fringilla passerina.

Yellow-winged Sparrow, Quail Sparrow, Cricket Sparrow. Kirtland, Ohio Geol. Surv., 1838, 164.

This little sparrow is local in its distribution, but may be fairly common in suitable regions, over the entire state. Its diminutive size and weak voice serve to hide it from all but the unusually interested. It seldom essays a higher perch than the top of a fence-post, and is usually content with a weed stalk or bunch of grass. It nests on the ground in meadows or neglected fields.

The food consists of insects and weed seeds and grain, but almost half of the whole food consists of injurious insects, and the grain is waste. The seeds are wholly of injurious weeds and grasses. As a destroyer of injurious insects this sparrow leads all the sparrows and equals some of the larger birds, like the Robin, which are supposed to feed largely upon insects and worms.

It appears in Ohio during the last week in April and remains until the first of October. During this time it must be looked for on the uplands, not in low places.

\section{9. (54\%.) Ammodramus henslowil (Aud.). $9 \%$. Henslow Sparrow.}

Synonyms: Coturniculus henslovii, C. henslowi, Emberiza henslowii.

Henslow's Bunting, Henslow's Grasshopper Sparrow. Jones, Auk, XII, 1895, 241.

Dr. Wheaton gives it in his catalogue of 1882 , citing references to Audubon, Birds Am., III, 1841, 76, and his own publications based upon Audubon's statement and upon a supposed specimen which Dr. Wheaton collected in the vicinity of Columbus in 1856 , which proved to be the young of $A$. s. passerinus. Dr. Wheaton eliminates these records and says, "In all probability Henslow's Bunting will be found not uncommon in restricted localities, particularly in the 
southern and western portions of the state." It seems, therefore, that the reference given above should stand as the first published record for the state. During the entire summer of 1894 this sparrow was found in considerable numbers about Oberlin, and several specimens were taken. I have looked for it in vain every year since then. There are no other reports of its occurrence within the state.

\section{0. (549.1.) Ammodramus nelsoni (Allen). - Nelson Sparrow.}

Synonyms: Ammodramus caudacutus nelsoni.

Nelson's Sharp-tailed Sparrow.

To Mr. Robt. J. Sim, of Jefferson, belongs the honor of adding this interesting bird to our state list. The bird was captured in the vicinity of Geneva, Ashtabula county, on May 1\%, 1902, and sent to me for identification. It proved to be a fine specimen in full spring dress. When captured the bird was on a bit of high, almost barren ground which lies between two arms of the extensive marsh near the lake shore. It seems probable that this secretive bird may be found sparingly throughout the state in suitable places.

\section{1. (552.) Chondestes grammacus (Say). 98. Lark Sparrow.}

Synonyms: Chondestes grammaca, Fringilla grammaca.

Lark Finch.

Wheaton, Field Notes, I, 1861, 129.

The appearance and spread of this, one of the most beautiful singers among the sparrows, is very interesting. Dr. Wheaton records the first ones seen in 1861. In 1882 it had spread well over the southern half of the state, at least as far as the Scioto river, but was not known north of the central portion. In 1890 , when I came to Oberlin, it was not known in Lorain county, but two years later Mr. L. M. McCormick found it on the Vermilion river bottoms. Since that time it has been found regularly, but in small numbers in the western half of the county, and has also reached 
Cleveland. Mr. I. A. Field has found it not uncommon at Granville and at Licking reservoir. It has not been reported from the eastern third of the state, but may be found there within a few years.

This is one of the great grasshopper-eating sparrows. During its stay it eats almost no grain, but does eat grass, clover and weed seeds, and numbers of weevils, besides the grasshoppers. It is therefore deserving of protection, and should never be persecuted.

It does not reach Ohio before the first of $\mathrm{May}_{2}$ and is gone again early in September. It must be looked for in fields bordering woods, where it nests on the ground.

\section{2. (554.) Zonotrichia leucophrys (Forst.). 99. White-crowned Sparrow.}

Synonyms: Fringilla leucophrys, Emberiza leucophrys.

White-browed Sparrow, White-browed Crowned Sparrow, White-crowned Bunting.

Audubon, Orn. Biog., II, 1834, 88.

There is little danger of confusing this with the next species in the spring, but far more in the autumn when the black head stripes of spring have given place to brown, and the white is reduced to gray. A little careful attention will discover the difference between them at any time.

In Lorain county we look for the White-crowns in the brush fringing woods. Sometimes the White-throats may invade their favorite places, but I have never found them invading the thickets which the White-throats regard their own. This species is strictly migratory, and has never been known to breed in Ohio, although Dr. Kirtland recorded them in July, 1850, near Cleveland.

While with us the food consists of vegetable matter threefourths to the animal matter one-fourth. Of the vegetable matter but a small proportion is grain, and a good proportion of that is probably waste. Some fruit is eaten during the summer, but none during the southward journey, or so little as to amount to nothing. The animal food is about a third caterpillars, the rest being ants, wasps, beetles and 
but few grasshoppers. It would thus appear that this sparrow is deserving of protection for the large numbers of weed seeds destroyed, and for its part in keeping in check the insect pests.

The White-crowned Sparrow reaches Ohio during the first five days of May and remains nearly two weeks. It returns again early in October and remains about two weeks.

203.

\section{(558.) Zonotrichia albicollis (Gmel.). 100.} White-throated Sparrow.

Synonyms: Fringilla pennsylvanica, F. albicollis.

White-throated Crown Sparrow, Peabody-bird, White-throat, Yellow-browed Sparrow, Bush Sparrow.

Kirtland, Ohio Geol. Surv., 1838, 164, 183.

If the White-crowned Sparrow be considered common during its migrations the White-throat is abundant usually. There is no direct evidence that it ever breeds in the state. It prefers the brushy tangles bordering woods, but may be found in almost any brushy places away from woods, particularly if it be abundant. It associates with Song, Field and Vesper Sparrows more or less, and with Juncos sometimes. The clear, whistled call or song may rarely be heard during the southward movement, but is given full-voiced during the northward one. To one familiar with the bird its alarm call is characteristic.

Weed seeds comprise half of what this sparrow eats, only 3 per cent. is grain; about 30 per cent. is wild fruit in the season of fruit. The insects eaten are chiefly harmful species. The debt is therefore wholly on our side of the account.

The White-throat reaches northern Ohio from its winter sojourn in the southern counties, early in April and remains well into May. It returns ágain late in September and remains about five weeks. 
204. (559.) Spizella monticola (Gmel.). 101. Tree Sparrow.

Synonyms: - Spizella montana, Fringilla canadensis, F. monticola.

Winter Chippy, Winter Chip-bird, American Tree Sparrow, Canadian Sparrow.

Kirtland, Ohio Geol. Surv., 1838, 164.

Tree Sparrow is by far our most abundant winter bird. It ranges both woods and fields, cleaning up every weed patch in the country. It lives in flocks of from ten or a dozen to several hundred individuals, and not infrequently sings in the dead of winter. One could not watch a flock of these birds for five minutes and retain a fit of the "blues." In the coldest and stormiest weather they find something to be happy about.

These birds seem to have a preference for grass seed, and will clean up anything that may be left exposed. But surely no thrifty farmer will leave his millet or timothy shocks out all winter long. In the absence of cultivated grasses great quantities of injurious grass seeds are destroyed. Only two per cent. of animal matter is eaten, hence the service of these birds lies in the weed seeds destroyed.

They reach Ohio about the beginning of the second week in October and remain until the middle of April, or sometimes even into the last week of April.

205. (560.) Spizella socialis (Wils.). 102.

Chipping Sparrow.

Synonyms: Spizella domestica, Fringilla socialis.

Chippy, Chip-bird, Hair-bird, Chipping-bird, Chipper. Kirtland, Ohio Geol. Surv., 1838, 164.

This sociable little bird is one of the door-yard birds which must be well known to all who take any interest in their feathered visitors. He may nest in the vine which covers the trellis, if not disturbed; or at least in one of the ornamenal trees in your yard, or in the grape-vine. Some have supposed that this and the Tree Sparrow were the same, but this sparrow goes south in winter. It is really 
abundant during the entire summer throughout the state.

The food consists of 62 per cent. vegetable to 38 animal matter. Only 4 per cent. of the food is grain, and there seems to be no evidence that any, fruit is eaten. Of the 38 per cent. of animal food a large part consists of the caterpillars of some of our most injurious insects. In lárge part these are such insects as other birds do not find because they are afraid to come so near human habitations. Although not larger than your thumb, this little bird is among the most useful of our sparrows.

It may be a resident in the southern counties, unless the weather is too severe. In northern Ohio it appears close to the first of April, but does not become common before the last of the month. The last ones leave the lake shore about the middle of October.

206. (563.) Spizella pusilla (Wils.). 103. Field Sparrow.

Synonyms: Fringilla pusilla, F. juncorum, Spizella agrestis.

Wood Sparrow, Bush Sparrow, Field Chippy, Red-billed Chippy, Feo-feo.

Kirtland, Ohio Geol. Surv., 1838, 164.

The Field Sparrow is really a bush-haunting sparrow, and is not infrequently called the brush sparrow. The brush fringing woods is the favorite haunt of this species. Brushy pastures are usually full of them and their nests. Their peculiar accelerando song is characteristic of such places.

The food habits and food are very similar to those of Chipping Sparrow. Both deserve strict protection.

The Field Sparrow spends the entire winter south of Ohio, and returns during the third week in March, rarely earlier. It remains well into October, and may linger until November in the extreme southern part of the state. 


\section{0\%. (56\%) Junco hyemalis (Linn.). 104. Slate-colored Junco.}

Synonyms: Fringilla hyemalis.

Snowbird, Eastern Snowbird, Black Snowbird, Common Snowbird, Junco, White-bill.

Kirtland, Ohio Geol. Surv., 1838. 164, 183.

This "Snowbird" is a winter resident over the whole state, but is not usually common during January and February in the extreme north. When it is present during these months it is pretty closely confined to the deeper stream gorges, where it finds food, and protection from the cold winds. In the central and southern parts of the state it may be found with the flocks of Tree Sparrows and Goldfinches, well scattered over the country. There it may pass the night in the corn shocks.

During the winter Junco eats weed and grass seeds almost exclusively, only nine per cent. of its entire food being animal. There is so little grain eaten that it does not figure. Hence the Junco is a great aid to the agricultural interests in the destruction of weeds.

Junco appears in northern Olhio about the first of October and within a week has made his way to our southern border. He leaves that border about the middle of April, often later, but tarries along the lake shore until the first of May.

208. (575a.) Peucata astivalis bachmanil (Aud.). Bachman Sparrow.

Synonyms: Fringilla bachmanii.

Oak-woods Sparrow.

Henninger, Bulietin Michigan Orn. Club, II, 1898, 7.

The first specimen was captured by C. M. Weed, August 18, 1890, at Columbus. The specimens reported by Rev. Mr. Henninger in the above reference were taken on April 23, and a second observed on May 3, 189\%, at South Webster. Miss Laura Gano reports several on April 2\%, and later, on Grosbeck Hill, Avondale, and College Hill, Cincinnati. Leander S. Keyser sends a questionable record for Clarke county. The invasion has been from the south- 
west, with an apparent intention of remaining to possess the state. Let us hope so.

209. (581.) Melospiza cinerea melodia (Wils.). 105. Song Sparrow.

Synonyms: Melospiza fasciata, M. melodia, Fringilla melodia, F. fasciata.

Silver-tongue.

Kirtland, Ohio Geol. Surv., 1838, 164.

Next to the Chipping Sparrow, this is probably our best known sparrow (always omitting mention of Britain's constant representative). It is present during the entire year in all parts of the state, but, unlike Junco, is far less common in the northern third in winter than elsewhere, and far less than it is during the summer. In summer it lives in the brushy tangles bordering woods and swamps, or the fields where weeds are allowed to grow, or even the back yards in the more thinly settled parts of towns and villages. In winter it loves brush piles in the woods, provided there is a good supply of food at hand. It is also found in some numbers in the thick tangle of grass and sedges bordering the swamps and bogs. It begins to sing early in February if there be bright days. The early spring songs differ from the later ones.

Only six per cent. of the food of this sparrow could possibly be of any use to man, while the weeds and injurious insects destroyed are something enormous in quantity when the abundance of the species is considered. It is true that its increasing familiarity tends to develop in it a taste for ripe fruits and more grain, but the useful things destroyed are so completely overbalanced by the good it does that we can afford to freely forgive and forget.

- The great increase in the numbers of this sparrow in Lorain county occurs about the first of April; then large numbers arrive from the south and swell the numbers already here.

r...

: 
210. (583.) Melospiza lincolnit (Aud.). 107. Lincoln Sparrow.

\section{Synonyms: Fringilla lincolnii.}

Lincoln's Finch, Lincoln's Song Sparrow.

Wheaton, Ohio Agri. Report, 1874, 566.

Little seems to be known of this sparrow. Its close resemblance to Song Sparrow probably causes it to be confused with that species. It is nowhere conmon in the state, even during the height of the migrations. It does not breed with us, but passes north. I have usually found it in low brushy woods, rarely in the fields bordering woods. It skulks about in the grass and weeds-more than the Song Sparrow, and has a very different song. One would not confuse the two a second time. Rev. Mr. Henninger regards it as common during the migrations in Scioto county.

It arrives in southern Ohio early in April, but Lorain county records all fall in May. It is not unlikely that the birds passing up the Scioto river are earlier than those which travel overland to reach Lorain county. The birds stay but a few days and pass north. In the autumn they return late in September or early in October.

\section{1. (584.) Melospiza georgiana (Lath.). 106. Swamp Sparrow.}

Synonyms: Melospiza palustris, Fringilla palustris, F. georgiana.

Swamp Song Sparrow, Spotted Swamp Sparrow. Kirtland, Ohio Geol. Surv., 1838, 164.

The Swamp Sparrow is so much confused with the Song and other brush-haunting sparrows that it is difficult to determine its exact standing. Judging from the reports it is not common during the migrations. It is reported as breeding near Circleville, by Dr. Howard Jones, who found a nest in May, 1881, which contained five eggs. The bird was shot.* I have looked for it in vain from Cleveland to - Sandusky on the lake shore, in summer. My own experience with it would indicate that it is fairly common during

*Illustrations of the Nests and Eggs of Ohio Birds, p. 186. 
the spring migrations in Lorain county. It frequents rather wet woods which are much grown with brush, as well as the more swampy places.

In food habits this sparrow is not injurious, but its preference for swampy places, where it feeds upon the insects and seeds, does not give it a high standing as a beneficial species. However, it must be classed as one of the sparrows which does more good than harm.

This sparrow reaches Lorain county about April 21, and remains until about the middle of May, returning again late in September for ten days or two weeks.

\section{2. (585.) Passerella iliaca (Merr.). 108. Fox Sparrow.}

Synonyms: Fringilla iliaca.

Eastern Fox Sparrow, Fox-colored Sparrow, Rufous Sparrow.

Kirtland, Ohio Geol. Surv., 1838, 164.

This is a common migrant both spring and autumn. It is found in the brushy woods in company with the other sparrows which haunt such places, but it seems to feel an aloofness to them. It is rather slow and sedate in carriage, not skulking in the brush piles as much as the others.

Fox Sparrow is fond of millipeds in April, and eats many ground beetles during that month also. Of the 86 per cent. of vegetable matter which constitutes its food, some 30 per cent. consists of the seeds of fruit. The remaining vegetable matter is largely seeds of ragweeds and polygonum. While some of the insects are useful, and possibly soms of the fruit is cultivated, the destruction of weed seeds is so large that the birds perform a great service to agriculture.

This is one of the early spring sparrows, arriving at Oberlin about the middle of March and remaining five weeks. It returns again during the last week in September, or the first week in October, and remains a month. 
213. (58\%.) Pipilo entthrophthalmus (Linn.). 109. Towhee.

Synonyms: Fringilla erythrophthalma.

Towhee Bunting, Chewink, Ground Robin, Marsh Robin, Red-eyed Towhee, Jewee, Joree, Pink-pink, Wink, Winkwink, Pipilo, Turkey Sparrow.

Kirtland, Ohio Geol. Surv., 1838, 164.

Towhee is a resident over most of the state, but in small numbers north. It is likely that the resident birds are males while the females are more migratory. In northern Ohio the winter birds must be looked for in well protected places where food is easily obtainable. During the summer the Towhee may be found in almost any thicket bordered woods, or in the lower brushy second growth. I have found nests in the higher, more open woods, as well as in the brushy tangles. No one who visits the woods can have failed to make the acquaintance of this strong-voiced bird.

The food habits do not seem to have been carefully investigated, but from the structure and general habits one might infer that this rather unsparrow-like sparrow feeds more after the fashion of the Robin. Such insects as haunt the ground are eaten in considerable quantities, as well as the weed seeds that may be found in the woods. It is certainly true that Towhee is useful as a weed destroyer.

The migrating females reach southern Ohio about the middle of April and depart about the middle of November. The migrating males reach Oberlin about the middle of March, and but few remain after the first of November.

214. (593.) Cardinalis cardinalis (Linn.). 110. Cardinal.

Synonyms: Cardinalis virginianus, Fringilla cardinalis, Pitylus cardinalis, Loxia cardinalis.

Cardinal Redbird, Crested Redbird, Top-knot, Redbird. Áudubon, Orn. Biog., II, 1834, 366.

Cardinal is now a common resident over the entire state. Ten years ago it was scarce in Lorain county, and even now is far less numerous at the lake shore than twenty miles 
south. Lately it has appeared at London, Ontario. Clearly it is extending its range from year to year. With more thorough protection it will soon become one of our most familiar birds.

This large, strong beaked bird is made for a diet of seeds which most other sparrows could not crush. I sometimes wonder what the birds which apparently spend all their time in towns and villages find to eat there. But there are always gardens with more weeds than vegetables. Weed seeds must form a large proportion of its food, with a small proportion of insects and fruit. I have yet to hear complaints about the destructiveness of this brilliant plumaged bird. Its loud, clear whistled calls and song are familiar to most persons, whether they go into the woods or not.

Away from towns and villages the birds are thicket haunters. They are often more numerous along the courses of streams than elsewhere, especially during the winter.

\section{5. (595.) Zamelodia ludoviciana (Linn.). 111. Rose-breasted Grosbeak.}

Synonyms: Goniaphea ludoviciana, Fringilla ludoviciana, Coccothraustes ludoviciana, Guiraca ludoviciana, Hedymeles ludoviciana, Habia ludoviciana.

Rose-breasted Song Grosbeak, Rose-breast, Redbreast, Redbreasted Song Grosbeak, Red-breasted Grosbeak, Potatobug Bird.

Audubon, Orn. Biog. II, 1834, 166.

The Rose-breasted Grosbeak is hardly common as a migrant in the southern half of the state. It is a summer resident in the northern half, but is rare as far south as Columbus, and not common at the lake shore. It is not infrequently seen among the shade trees bordering village streets, and may nest in the parks if not persecuted. Its favorite nesting-place is a woods in which there are patches of second growth or large bushes. Briar patches and brushy tangles do not seem to offer many inducements.

The "gross" beak is adapted for crushing strong seeds, upon which it feeds to a large extent. It is also accused of eating ripe fruit. I have seen it eating the buds from 
trees. The birds are not numerous enough to be of much use or harm, but they are certainly more useful than harmful.

These grosbeaks reach Oberlin close to the first of May and remain until the middle of September.

216. (598.), Cyanospiza cyanea (Linn.). 112. Indigo Bunting.

Synonyms: Passerina cærulea, Passerina cyanea, Fringilla cyanea, Tanagra cyanea.

Indigobird, Indigo Painted Finch, Indigo Painted Bunting, Indigo Bluebird, Blue Linnet, Green Linnet, Indigo, Green Bird, Blue Nonpareil.

Kirtland, Ohio Geol. Surv., 1838, 164, 183.

The Indigobird is a common summer bird over the entire state, being almost abundant in some places. It is fond of any sort of thicket, from the brush fringing woods and weedy briar tangles to the rank vegetation bordering streams, marshes, and ponds, where it breeds.

Its food is similar to that of the Field Sparrow, with which it lives in perfect harmony. It is therefore one of the more useful of sparrows, of great service to agriculture because it is so numerous.

It reaches the state about the first of May and stays until October.

21\%. (604.) Spiza americana (Gmel.). 113.

Dickcissel.

Synonyms: Euspiza americana, Fringilla americana, Emberiza americana.

Black-throated Bunting, Little Meadowlark, Little Field Lark, Judas Bird, Judas Iscariot.

Kirtland, Ohio Geol. Surv., 1838, 164, 183.

Dr. Wheaton's statement that this species is an "Abundant summer resident from May to September, in Middle and Southern, less common in Northern Ohio," hardly applies now. It is fairly common, and locally abundant, east to Licking county, and north to Columbus, but is rare north to Cleveland, and seems to be wholly unknown east of Cleveland. It is more numerous in the northwestern part 
-of the state than east of Toledo. It is a summer resident wherever it occurs, living and nesting in the fields much after the manner of the Meadowlark.

Unlike most of the sparrows, Dickcissel eats more than twice as much animal matter as vegetable matter. Of the vegetable matter only three per cent. is grain, the rest being weed seeds. Of the animal matter fully half of all food eaten is grasshoppers and crickets. A small percentage of useful insects is eaten, but it is so small a proportion that no account of them need be taken. This is, therefore, one of our most useful summer sparrows.

Rev. Mr. Henninger states that it is a rare summer resident in both Pike and Scioto counties where it has been unknown until within the last six years.

\section{Family TANAGRIDE. Tanagers.}

Only one of the two members of this family found in Ohio is distributed over the entire state. Both have brilliant plumage, and both are fairly good singers. While they are woods-haunting birds, the Scarlet Tanager frequently nests in parks and shade trees in cities and towns.

\section{8. (608.) Piranga erythromelas Vieill. 82. Scarlet Tanager.}

Synonyms: Pyranga rubra, Tanagra rubra, P. erythromelas.

Black-winged Redbird, Pocket-bird, Scarlet Sparrow, Canada Tanager, Red Tanager, Scarlet Black-winged Tanager. Kirtland, Ohio Geol. Surv., 1838, 164.

In spite of his brilliant dress, and in spite of the fact that he is one of our common birds in every part of the state, there are many persons who do not know the Scarlet Tanager. When chance throws him so directly in their path that they must see him, he is heralded as the rarest of birds dropped down from - Limbo! How many there are who, having eyes, see not! There is no part of the state where this is not a common summer resident. It sometimes nests in our city and village parks, well up among the branches. This bird destroys insects, weed seeds, and eats wild 
fruit. I have seen it cutting the tender buds from elm trees and eating them. It is not injurious in any way, and is of considerable service to the farmer.

The Scarlet Tanager reaches Ohio about the first of May, frequently earlier, and returns to the south late in September.

219

(610.) Piranga rubra (Linn.). 83.

Summer Tanager.

Synonyms: Pyranga æstiva, Tanagra æstiva, Fringilla rubra.

Summer Redbird, Rose Tanager, Red Bee-bird, Flaxbird, Redbird, Mississippi Tanager, Variegated Tanager. Audubon, Orn. Biog., I, 1831, 232.

The distribution of this southern species in our state is rather remarkable. It is found in Trumbull, Portage and Columbiana counties in the east, but does not go beyond Franklin in the center nor Montgomery in the west, except casually. It thus appears to remain close to the Ohio river or its main tributaries. Its northeast range appears to be due to a recent movement, since Dr. Wheaton says nothing about it. There is no direct evidence, except the northeast movement, that its range is being much extended. No doubt there will be records of individuals from further north, as our activity in field work increases, but any considerable extension of its range in the next half century does not seem likely.

The deep ravines and gorges of the southeastern and southern parts of the state seem to be the favorite abiding places of this not very brilliant tanager. During a boating trip down the Muskingum and Ohio rivers, from Zanesville to Ironton, with my friend and fellow bird student, - Rev. William Leon Dawson, during August of 1902, we found these birds at almost every stop below Marietta. They are not uncommon about McConnellsville, where Messrs. C. H. Morris and E. J. Arrick have found them nesting, but we were not fortunate in finding them during our stay there. Mr. Arrick well described the peculiar call note, which was often heard along the Ohio river, by the 
syllables, cluckity chuckity chuck, or chuckity tuckity tuck.

This tanager's food is like that of the Scarlet Tanagerinsects, varied by frequent helps of weed seeds and wild fruits in their season. It is distinctly useful.

It seems to slightly precede the Scarlet Tanager in its arrival, appearing during the last week in April and tarrying well into September.

Family Hirundinide. Swallows and Martins.

Five swallows and one martin spend the summer in Ohio. These birds pass most of their days on the wing feeding and playing. The martins are less active on the wing, but are good flycatchers nevertheless. All of this family not only rival but exceed the true Flycatchers as destroyers of flying insects, usually feeding upon the insects which fly higher or in the more open fields. Some glean from the top of the grass as they fly. A large colony of swallows under the eaves of a stock barn is the best friend of the milkman.

220. (611.) Progne subis (Linn.): 76.
Purple Martin.

Synonyms: Hirundo purpurea, H. subis, Progne purpurea.

Martin, Purple Swallow, Black Martin, Black Swallow, Great American Martin, Blackbird Swallow.

Kirtland, Ohio Geol. Surv., 1838, 162.

Dr. Wheaton reported this as an "Abundant summer resident." If abundant anywhere now it is not so reported. There may still be a few colonies where large numbers of individuals breed. I have seen more at Lewiston reservoir, where we found them nesting in the stumps projecting above the water, than elsewhere. But even here they were not abundant. It seems clear that twenty years have served to greatly diminish their numbers over the entire state. What the cause of this decrease may be is hard to determine. Many have declared that since both Martins and English Sparrows use the bird-houses, and since the sparrows are on hand all winter, the Martins find their homes preempted when they return, and are unable to regain possession. If, 
as we are told by Dr. W. B. Barrows in his report upon the English Sparrow, the sparrows are successful in driving the Martins away only half of the time, that would fully account for the decrease in numbers. There can be little question that at least a part of the decrease must be attributed to the sparrow.

It should not be necessary to state that the food of the Purple Martin consists largely of flying insects. During the time the young are fed the old birds are driven to search the ground as well as the air for grasshoppers and other large insects to appease the appetite of the always hungry young ones. Their services to mankind will only be appreciated when they are gone and nothing takes their place as destroyers of the insects which cause us so great annoyance.

The Martin not infrequently reaches our southern border during the second week in March, and the lake shore during the third week. It moves south again about September 15. Rev. Mr. Henninger reports an albino at South Webster, Scioto county, March 29, 1895.

\section{1. (612.) Petrochelidon lunifrons (Say.). $7 \%$. Cliff Swallow.}

Synonyms: Hirundo fulva, H. lunifrons.

Eave Swallow, Crescent Swallow, Mud Swallow, Mud Dauber, Square-tailed Barn Swallow, White-fronted Swallow, Rocky Mountain Swallow, Republican.

Bonaparte, I, 1825, 65.

The Cliff Swallow nests in colonies, and is therefore common and may be abundant in a few places. It is hardly common in Lorain county. There is no record of a colony nesting away from human habitations in Ohio since its settlement by civilized people. Their favorite nesting-place is under the eaves of a barn or other similar building, often in companies of several hundred, where the building affords enough room. The flask-shaped mud nests are familiar to every farm boy.

Like the other swallows, the Cliff Swallow feeds upon 
the insects that fly a good deal, catching them in mid-air. These swallows are much liked by intelligent stock farmers and dairymen, for they keep in check the flies that annoy the herds and milch cows.

The Cliff Swallow appears at Oberlin during the last week in April. It leaves its nesting-places early in July and is gone south by the last of September.

222. (613.) Hirundo erythrogaster Bodd. 78. Barn Swallow.

Synonyms: Hirundo rufa, H. horreorum, H. erythrogaster var. horreorum, Chelidon erythrogastra.

Fork-tailed Barn Swallow, American Barn Swallow, House Swallow.

Kirtland, Ohio Geol. Surv., 1838, 162.

This is the most common and familiar of our swallows, always remembering that the Chimney Swift is not a swallow. While it is not in such great numbers as the Vesper Sparrow, it may be fairly called abundant in practically all parts of the state as a summer resident. It nests in barns or almost any large out-building, or unused house; or under bridges. There is no record of the nests of this species under cliffs or in caves, as its habit was before civilized man appeared in America. In Oberlin the Barn Swallow is a familiar bird, nesting in any barn that may be left open for it. One may see them flying about the streets catching insects at any time of day, during the summer.

This swallow frequently gleans from the grass tops, as it skims along without apparent effort. House flies are also eaten, as well as the species of dancing flies which annoy the wheelman.

The appearance of Barn Swallows in spring largely depends upon the weather. They are such strong fliers that they may venture north for a single day early in March, during one of the spring-like days which are pretty sure to come, or they may tarry south until early April. The most have gone south by the first of September, but individuals usually remain until the last week in September. 
223. (614.) IrIdoprocne bicolor (Vieill.). 79. Tree Swallow.

Synonyms: Hirundo bicolor, Tachycineta bicolor.

White-bellied Swallow, Blue-backed Swallow, Field Swallow, River Swallow, Wood Swallow, Green-blue Swallow, Black-and-white Swallow.

Kirtland, Ohio Geol. Surv., 1838, 162.

Dr. Wheaton reported this as a "Very common summer resident." The only place where I have found it abundant was at Lewiston reservoir in July, where the birds swarmed about the multitudes of stumps in which they nested. Not even the English Sparrow ventured to disturb them there. In late July and early August the Tree Swallows roost in our northern marshes at night, or line the telegraph wires which pass such localities. They are abundant enough then, but where they have come from is a mystery. Certainly not from the immediate region, for they are not found except in small numbers during the summer. A few are willing to occupy the bird boxes erected for them and the Martins and Bluebirds, but most of them prefer to cling to their primitive habits of nesting in hollow trees.

The food differs from that of the other members of this group only in the difference in insects which naturally inhabit such regions as these swallows frequent a part of the year: During the weeks when the swallows are collecting for their southward journey they roost together in mixed companies of the several species, but one species usually predominates.

The Tree Swallows arrive and depart with the Cliff Swallows.

224. (616.) Clivicola Riparia (Linn.). 80. Bank Swallow.

Synonyms: Cotyle riparia, Hirundo riparia, Riparia riparia.

Sand Martin, Sand Swallow.

Kirtland, Ohio Geol. Surv., 1838, 162.

The Bank Swallow shifts its breeding-places to suit local conditions and therefore may be reported as common at one 
locality for a term of years and afterward wholly absent. The banks in which it burrows to rear its brood are constantly changing, sometimes wholly disappearing. Railroad cuts furnish suitable places for a short time, and then become unfitted by the caving of the perpendicuar banks to form a sloping bank. River banks and the clay banks facing Lake Erie are not alike two years in succession. Where a colony of some 200 pairs of the Bank Swallow nested for three years not one is to be found now. The bank caved off back of the nests twice in succession during the same spring, both times after many nests had been finished and the eggs deposited. That was too much for the swallows. Now there is but one large colony in Lorain county on the lake shore, but there are several small colonies. At the lake shore the birds might justly be called decidedly common, but elsewhere in the county they are scarce. Before the spread of the English Sparrows into the country hamlets Bank Swallows nested in the shale cliffs on Vermilion river, but now the sparrows occupy all of the available nesting-places.

With the restriction that this swallow may be found where cliffs or banks afford nesting-places, and not over the country generally, it may be called common over the entire state, during the summer. It is, of course, locally common.

Bank Swallow reaches the lake shore about the beginning of the last week in April, leaves its nesting-places early in July, and has gone south by the middle of September.

225. (61\%.) Stelgidopteryx Serripennis (Aud.). 81. Rough-winged Swallow.

Synonyms: Cotyle serripennis, Hirundo serripennis.

"Bank Swallow," Rough-wing.

Kirkpatrick, Ohio Farmer, VIII, 1859, 290.

This species is so little known, probably because of its resemblance to the Bank Swallow, that reports are meager. Dr. Wheaton says, "Next to the Barn Swallow, this appears to be our most abundant species." Judging from my own 
observations in several representative places in the state, such is not the case now. The term common better applies. These birds may be found about bridges, perpendicular rocky cliffs, and sometimes in company with the Bank Swallow, with which it nests to a limited degree. I have never seen it in such large companies as the Bank Swallow, but six to ten birds together is not uncommon. The nest is usually made in a crevice of the rocks, and is not made by the birds, although it may be cleared of loose earth or rubbish.

The food is not much unlike that of the other members of this group. It may be seen swinging back and forth over the fields or up and down a rock walled stream, usually feeding below the top of the cliffs.

The Rough-wing arrives a few days later than the Bank Swallow, and does not leave the streams before the middle of July. It has gone south by the first of September.

\section{Family Ampelid As. Waxwings.}

Both waxwings have been found in Ohio, only the Cedar regularly. They are almost silent birds, having no true song and but a weak chatter. They are erratic in habits, usually occur in flocks, and frequently nest in our orchards. Their plumage is soft and delicate. The conspicuous crest is a good field mark.

226. (618.) Ampelis garrulus Linn. 74.

Bohemian Waxwing.

Synonyms: Bombycilla garrula, Lanius garrulus.

Bohemian Chatterer, Northern Chatterer, European Chatterer, Waxen Chatterer, Northern Waxwing, European Waxwing.

Kirtland, Am. Journal Sci. and Arts, XL, 1841, 20.

There is nothing to add to what Dr. Wheaton has said about this winter bird. From that account it appears that the species was a somewhat regular winter visitor in the vicinity of Cleveland to about 1860 . Since that time I have been unable to find records for Ohio. It is just possible that 
the bird does reach our northern border sometimes still, but is not distinguished from the Cedar Waxwing. Observers should be on the watch during our cold weather, and especially be suspicious of any Waxwing which appears during such severe cold.

Dr. Kirtland states that these birds were "attracted by the berries of the mountain ash and hawthorn, and the fruit of the persimmon."

22\%. (619.) Ampelis Cedrorum (Vieill.). 75.

Cedar Waxwing.

Synonyms: Bombycilla carolinensis, B. cedrorum.

Cherry Bird, Cedar Bird, Carolina Waxwing, Southern Waxwing, Little Waxwing, Carolina Chatterer, Spider-bird.

Kirtland, Ohio Geol. Surv., 1838, 162.

This is a somewhat irregular species, but may be considered a common resident over the entire state. However, i.t is sometimes scarce or wholly wanting from some localities and abundant at others during the same time. It is generally seen in flocks even during the nesting season.

Its food consists of 13 per cent. animal and 87 vegetable matter. A few snails are eaten, but the bulk of the animal matter consists of beetles, with a few bark and plant lice. The vegetable matter is 87 per cent. wild fruit and seeds and only 13 per cent. cultivated fruits, with the probability that a large part of the raspberries and blackberries are also wild fruit. Early cherries are scarcely touched. At any time the Cherry-bird prefers mulberries to cherries. A single bearing mulberry-tree has saved a whole orchard of cherries. A Cherry-bird was brought to me which had killed itself by eating too many ripe mulberries. Taken the year through this bird is far more useful than harmful and should be protected.

\section{Family Laninde. Shrikes.}

The name "Butcher-bird" was applied to members of this family because of their habit of impaling their victims upon thorns. It was long supposed that they gloated over the 
struggles and sufferings of their victims like veritable barbarians. That this is a libel on the character of the shrikes any one may prove by studying them at first hand. They are pretty fair singers, but the summer form is seldom heard singing unless one happens upon the performer unobserved. The Northern Shrike sings from his tree-top perch in the midst of a snowstorm in midwinter. All shrikes are solitary birds except while nesting and for some time after the young have left the nest.

228. (621.) Lanius boRealis Vieill. 72.

Northern Shrike.

Synonyms: Lanius septentrionalis, Collyrio borealis, Collurio borealis.

Great Northern Shrike, Butcher-bird, Great American Shrike, Great Butcher Shrike.

Kirtland, Ohio Geol. Surv., 1838, 163, 181.

This solitary shrike is a winter resident over the entire state, but it is irregular south and rare everywhere, except occasionally along the lake front. It visits towns and villages during extreme weather for the sake of the hordes of English Sparrows. In the fields and woods it is always on the lookout for field mice or other rodents, and unwary sparrows.

The food of this bird consists of birds 35 per cent., insects 40 per cent., mice 25 per cent. Of the birds many are English Sparrows. While the other birds are useful species they constitute less than 25 per cent. of the whole food. It seems clear, therefore, that, contrary to his reputation, the Butcher-bird is one of our useful winter visitors and should be encouraged to visit the settlements where English Sparrows are to be so easily found. The habit of impaling its victims on thorns has grown out of the necessity of storing food against a time of scarcity, and is not an indication of the savage or barbarous instincts so often attributed to these birds.

The Northern Shrike reaches northern Ohio about the first of October and the southern counties a week later. It sometimes tarries until the first of April in Lorain county. 
229. (622d.) Lanius ludovicianus migrans W. Palmer. 73 and $73 \mathrm{a}$.

Migrant Shrike.

Synonyms: Lanius ludovicianus, L. 1. excubitorides.

Loggerhead Shrike, White-rumped Shrike.

W. Palmer, Auk, XV, 1898, 257.

Awaiting the action of the A. O. U. committee on nomenclature upon the proposed subspecies migrans, there seems nothing left one but to accept this tentative name instead of reverting to the former now obsolete names, so far as the shrikes of Ohio are concerned. In the Oberlin College collection there are a few more specimens referable to $L$. ludovicianus excubitorides than to L. ludovicianus, with two or three specimens indeterminate. With such a condition illustrated by specimens taken within a few miles of Oberlin, this proposed creation of a new subspecies which shall eradicate the confusion hitherto so apparent, seems desirable. At any rate it is not wise to return to the old classification. The two names used by Dr. Wheaton will therefore refer to this new subspecies. It is clear from Dr. Wheaton's remarks that his mind was not at rest concerning the summer shrikes. The apparent shifting westward of the excubitorides form noted by him, and by Prof. Ridgway in Illinois, was not satisfactorily accounted for.

The food of this shrike differs from that of the Northern only in the larger percentage of insects eaten and the smaller percentage of birds. While feeding its young many snakes are killed, and many of the spiny caterpillars. Grasshoppers are eaten in quantities. It is clear, from the careful study of the food of this bird, and from the examination of stomachs, that it is far more beneficial than injurious, and should be protected at all times.

It appears certain that this form winters as far north as Columbus in small numbers. It is hardly common anywhere in the state, except locally. The southeastern counties are too deeply gashed and are so lacking in suitable nesting-places that it is practically absent from that region. 
This shrike reaches northern Ohio about the middle of March and returns south about the first of October.

\section{Family VIREONIDÆ. Vireos.}

Of the six vireos found in Ohio four remain to breed, and one of the four is found only in the southern parts of the state. These birds closely resemble the warblers in habits and carriage, but are more deliberate in their movements, and glean from leaves rather than from the twigs and stems, but they must sometimes make sallies into the air for flying insects, and frequently act like warblers. They usually sing all the time between mouthfuls, and may be known by their songs even when other characteristics fail. For the most part they are sober-colored, one species having a yellow throat. Their colors are shades of gray with some green and yellow. In contrast to the warblers, they are not patchy in color.

The vireos are preëminently leaf gleaners, but they sometimes catch flying insects after the manner of the warblers. Their food is therefore more largely eggs and larvæ of insects than the winged forms. It is just possible that they may take a little ripe fruit in its season, but if so, in too small quantities to count.

\section{0. (624.) Vireo olivaceus (Linn.). 66. Red-eyed Vireo.}

Synonyms: Vireosylvia olivacea, Muscicapa olivacea.

Red-eyed Greenlet, Red-eyed Flycatcher, Red-eye, Preacherbird.

Kirtland, Ohio Geol. Surv., 1838, 163.

This vireo is almost abundant in woods throughout the state. Its perpetual phrased song is likened to the admonitions of a preacher, and has given it the name of "Preacher Bird." Its woven pensile nest is an easy mark for the Cowbird, which is pretty sure to deposit one or more of its parasitic eggs in the nest. I have found three eggs of the Cowbird and but two of the rightful owner in one nest. The 
duped vireo seems to offer no protest to this persistent imposition. The birds are not confined to the woods, but frequently nest in our city parks. The noise of traffic may almost completely drown the cheerful voice, but it cannot stop it.

This vireo reaches the lake shore about the 23d of April and departs about the 25th of October.

\section{1. (626.) Vireo philadelphicus (Cass.). 67. Philadelphia Vireo.}

Synonyms: Vireosylvia philadelphica.

Brotherly Love Vireo, Brotherly Love Greenlet.

Baird, P. R. R. Report, IX, 1858, 335.

This vireo seems to be irregular as a migrant in Ohio. I have never found it in Lorain county, nor elsewhere in the state. If it were even fairly common it could hardly have escaped so many observers entirely.

Rev. Mr. Henninger found it late in April and again late in September, in southern Ohio.

232. (62\%.) Vireo gilvus (Vieill.). 68. Warbling Vireo.

Synonyms: Vireosylvia gilva, Muscicapa gilva.

Warbling Greenlet, Warbling Flycatcher.

Kirtland, Ohio Geol. Surv., 1838, 163, 180.

This is the vireo which lives in the shade trees and parks all summer. It is almost abundant over the entire state. The peculiar rolling song and rasping scolding notes must be familiar to all. They may be heard just outside your door at almost any time from May to August.

This vireo seems to travel with the Red-eyed Vireo, sometimes arriving a day or two earlier. Southern Ohio dates of arrival range from April 19 to May 9, while Lorain county arrivals range from April 28 to May 1 . They have left the lake shore by September 15, but tarry a month longer in the southern counties. 
233. (628.) Vireo flavifrons Vieill. 69. Yellow-throated Vireo.

Synonyms: Vireosylvia flavifrons, Lanivireo flavifrons.

Yellow-throated Greenlet.

Kirtland, Ohio Geol. Surv., 1838, 163.

Most people are not acquainted with this vireo, probably because it prefers the taller timber and is seldom seen about human habitations. It is hardly common as a summer resident except in certain localities where tall oak timber is plentiful. Its song closely resembles the song of the Redeyed, but may be readily distinguished after careful study of both.

This species arrives during late April, perhaps a little later than the two foregoing species, and remains until September.

234. (629.) Vireo solitarius. (Wils.). $\% 0$. Blue-headed Vireo.

Synonyms: Lanivireo solitarus, Muscicapa solitaria.

Solitary Vireo, Solitary Greenlet, Blue-headed Greenlet.

Wheaton, Ohio Agri. Report, 1860, 365, 375.

Like the Yellow-throated Vireo, this is little known, partly because it seldom gets out of the woods, and partly because it is strictly a migrant across the state. Its song has a fairly close resemblance to the song of the Red-eyed Vireo, but it is not difficult to distinguish after a little study. I have found the Blue-headed on the College campus and in the shade trees lining our streets.

This vireo reaches Lorain county the first week in May, usually near the first; or even the last days of April, is fairly common for a week, and passes north about the 15th of May. It returns about the middle of September, remaining but a short time. It leaves southern Ohio shortly after the middle of October. A better acquaintance with this bird will undoubtedly prove it to be not uncommon during the migrations across the state. 
235. (631.) Vireo Noveboracensis (Gmel.): 71. White-eyed Vireo.

Synonyms: Muscicapa noveboracensis.

White-eyed Greenlet, Little Green Hangingbird, Chickitybeaver, Politician, Hanging Flycatcher, Green Flycatcher. Kirtiand, Ohio Geol. Surv., 1838, 163.

The White-eyed Vireo is distinctly southern in its distribution, in Ohio. It is a fairly common summer resident in the southern half of the state, ranging at least to the southern border of Franklin county, but Dr. Wheaton did not find it at all at Columbus, nor have others found it there as more than a casual visitor. In the eastern half of the state it ranges north into Cuyahoga and Ashtabula counties, being fairly common at Jefferson all summer. There is no record for Lorain county. I did not find it in Medina county, where the conditions are unusually favorable, nor at either the Licking or Lewiston reservoirs. Dr. Wheaton regarded it as of local distribution over the state. If that be true at the present time evidence is lacking.

It reaches our southern horder early in May and retires southward early in September.

Family MNIOTILTID瓜. Wood Warblers.

The species of this family found in Ohio are both the most numerous and the most interesting of birds. Thirty-six species are regularly found, one has wandered from the east, and two belong to the Hypothetical List of the A. O. U. He who can resist the temptations to get into the woods which "Warbler Time" brings is hopeless from an ornithological standpoint! Most of them pass through the state twice each year, but fully fifteen species remain to breed while three others occasionally do. Some of the species which nest well north in the state in small numbers and are migrants elsewhere must be regarded as rare breeders, the most of the individuals passing well north to breed.

Most members of this group are insect eaters, but most of them also eat fruit and berries in their season, some of them to a considerable extent. Some are gleaners from leaf and 
branch, some feed largely upon the ground, while some catch flying insects after the manner of the true Flycatchers. All are useful birds and none seem to be at all injurious.

236.

(636.) Mniotilta varia (Linn.). 28. Black and White Warbler.

Synonyms: Mniotilta varia borealis, Sylvia varia, Motacilla varia.

Black-and-white Creeper, Black and White Creeping Warbler.

Kirtland, Ohio Geol. Surv., 1838, 163, 182.

Dr. Wheaton gives this warbler as a "Common summer resident." It is so reported by a few observers well scattered about the state, but is regarded by most as common only during the migrations. My studies in different parts of the state have convinced me that it is to be found breeding in suitable places over the entire state, but is common only locally. It breeds sparingly about Oberlin. During the summer it must be sought in the deeper high woods. Its creeping habits and weak song make it an inconspicuous bird at best, and in the deep shadows of the woods it may be easily overlooked.

This warbler is among the first of the great host of warblers which pass across the state-a few of them remaining all summer-late in April and early in May. It appears on our southern border about. April 25th, and our northern border about three days later. In Lorain county it is common up to the middle of May and then the few which remain to breed retire to the deeper woods. The last have left the county by the 25th of September.

23\%. (63\%.) Protonotaria citrea (Bodd.). 29. Prothonotary Warbler.

Synonyms: Motacilla citrea.

Golden Swamp Warbler, Willow Warbler, Golden Warbler. Wheaton, Ohio Agri. Report, 1860, 363, 373.

The distribution of this handsome warbler is largely determined by the special conditions favorable to its breeding. 
Dr. Wheaton says of it: "The Prothonotary Warbler is only known in this state as a summer resident in western Ohio, especially in the vicinity of St. Mary's reservoir." I have found it fairly common at Licking reservoir, in all three counties in which that reservoir lies; but it was not found at Lewiston reservoir in spite of the fact that breeding places seemed plentiful. In "Birds of Indiana," page 1022, Mr. Butler mentions a Cleveland record for this species. I have been unable to verify this record. Mr. Charles Dury reports its presence at Cincinnati and St. Mary's reservoir, as stated above. These are the only positive state records. It is likely that the bird occurs in other suitable localities in the state. Its local distribution is well illustrated by the finding of breeding birds in eastern Minnesota. There seems to be some indirect evidence that this species is extending its range northward where conditions are favorable.

I have no records of its migrations, but it must reach Licking reservoir early in May, for during the last week in May we found a nest which was the second for that pair of birds, the first having been robbed two weeks previously.

238. (639). Helmitheros vermivorus (Gmel.). 30. Worm-eating Warbler.

Synonyms: Helmintotherus vermivorus, Sylvia vermivora, Helinaia vermivora, Motacilla vermivora, Vermivora pennsylvanica.

Worm-eating Swamp Warbler, Worm-eater.

Kirtland, Ohio Geol. Surv., 1838, 163, 182.

Like the last species, this one is among those of more southern distribution. Dr. Wheaton regarded it as rare in summer. It now seems to be common in many places in the southern part of the state, and ranges well north in the eastern half, breeding in Cuyahoga and Ashtabula counties. There is a doubtful record for Lorain county. Without doubt this species is extending its range northward, and further study by trained men will no doubt greatly increase the Ohio records.

The Worm-eating Warbler reaches Ohio during the first 
week in May and departs southward about the middle of September.

239. (641.) Helminthophila pinus (Linn.). 32. Blue-winged Warbler.

Synonyms: Helminthophaga pinus, Sylvia solitaria, Vermivora solitaria, Certhia pinus.

Blue-winged Yellow Warbler, Blue-winged Swamp Warbler. Kirtland, Ohio Geol. Surv., 1838, 163, 182.

This warbler is tolerably common during the migrations, but is less numerous as a breeding bird over the entire state. Given a wet woods with a fringe of brush and the Blue-wing is pretty certain to be present. One hearing of the curious song is enough to fix it in mind. While the nest is placed near the ground in the grass or rarely low bushes, the birds must usually be looked for in the tree-tops, or at least in the upper branches of the taller trees. If the bird be near the ground it is pretty certain proof of the presence of the nest.

This warbler reaches northern Ohio during the last week in April, and remains until the middle of September.

240. (642). Helminthophila chrysoptera (Linn.). 33. Golden-winged Warbler.

Synonyms: Helminthophaga chrysoptera, Sylvia chrysoptera, Vermivora chrysoptera, Motacilla chrysoptera.

Blue Golden-winged Warbler, Golden-winged Swamp Warbler.

Kirtland, Ohio Geol. Surv., 1838, 163, 182.

The distribution of this warbler in Ohio seems to be almost identical with that of the Worm-eating Warbler, with the exception that it seems to be a little more northern. "It has been found in Lorain county a half-dozen times, but is not known to have bred there. It is reported as breeding in Cuyahoga and Ashtabula counties, and is common locally in the southern half of the state. It also nests on the ground, but is not so fond of the tree-tops for a perch. It is unwary, permitting a near approach. Its lazily uttered zee zee zee zee is unlike the song of any other bird, but might be mistaken for an insect. 
This Warbler reaches Lorain county during the first week in May. I have no autumn records of the return south. It probably tarries until the first of September at least.

241. (645.) Helminthophila rubricapilla (Wils.). 34. Nashville Warbler.

Synonyms: Helminthophaga ruficapilla, Sylvia rubricapilla, Vermivora rubricapilla, Sylvia ruficapilla.

Nashville Swamp Warbler, Nashville Worm-eater.

Kirtland, Ohio Geol. Surv., 1838, 168, 182.

The Nashville Warbler is a common migrant, passing entirely across the state twice each year. It is not confined to the woods but is just as common in the parks and along the tree-lined streets, and in the door-yards among the fruit and ornamental trees, busily engaged in cleaning out the insect pests from bud and leaf.

This warbler reaches Lorain county about the first of May and is common for two and sometimes three weeks, often tarrying until the 23d of May. It returns in force early in September and remains about four weeks. There is little doubt that this is a late date for the return of this and many other warblers, but the records show no earlier dates.

242. (646.) Helminthophilla celata (Say). 35. Orange-crowned Warbler.

Synonyms: Helminthophaga celata, Sylvia celata.

Wheaton, Ohio Agri. Report, 1860 363, 373.

Dr. Wheaton's statement that this is a "Rare spring and fall migrant" remains true to-day. The bird is little known. I have found it but a half-dozen times at Oberlin, and not more than one bird for each record. Once it was feeding in an orchard just out of the village, the other times in the woods low down in the brush.

My dates of spring migration fall within the first week of May. I have no autumn records. 
243 (64\%.) Helmintiophila peregrina (Wils.). 36. Tennessee Warbler.

Synonyms: Helminthophaga peregrina, Sylvia peregrina, Vermivora peregrina.

Tennessee Swamp Warbler.

Kirtland, Ohio Geol. Surv., 1838, 163, 182.

This is probably the most numerous warbler of the shade trees and orchards during both spring and autumn migrations. It passes entirely across the state, none remaining to breed. In spring it literally swarms about our trees and lawns, but is unnoticed by the majority of people, because it is so small and because its song is so like that of the Chipping Sparrow; and some insects. In autumn it is more confined to the woods, but is not uncommon in orchards and shade trees. It is one of our best friends, gleaning everywhere for the eggs, larvæ or the perfect insects which do so great damage to fruit. Yet I have known of fruit growers who made war upon them for eating off the buds! They are after the bug that eats the bud or the fruit.

The Tennessee Warbler is among the later warblers to arrive, appearing about May 5, and remaining two weeks. It passes south again in September, leaving the state during the first week in October.

244. (648a.) Compsothlypis americana usnez: Brewst. 37 (part).

Northern Parula Warbler.

Synonyms: Dendrœca tigrina, Perissoglossa tigrina, Sylvia americana, Parus americanus, Compsothlypis americana (part).

Blue Yellow-backed Warbler, Parula Warbler. Kirtland, Ohio Geol. Surv., 1838, 163, 182.

Judging only from the specimens in the Ohio State University and Oberlin College museums, six in all, this form is pretty clearly a regular migrant across the state in spring, during the first two weeks of May. There appear to be no breeding specimens in collections. It is not common anywhere, but is fairly numerous during favorable years for the spring migrations of the warblers. 
245. (648b.) Compsothlypis americana RAMalin压. Ridgway. 37 (part).

Western Parula Warbler.

The synonyms and reference should stand as in the preceding form. In "Birds of North and Middle America," Vol. II, 486, Prof. Ridgway gives the following reference: Read, Proc. Ac. Nat. Sci. Phila., vi., 1853 (n. Ohio). Mr. H. C. Oberholser also informs me that this is likely the breeding form for Ohio. A specimen in the Ohio State University collection, and one in the Oberlin College collection, both taken rather late for the migratory movement, are decidedly small. In the absence of contradictory evidence it seems necessary to regard this form as the Ohio breeding Parula Warbler. It is little known in the breeding season, having been noted only by Dr. Langdon and Mr. Dury near Cincinnati. It would appear to be a little later than the preceding form in its migrations.

\section{6. (650.) Dendroica tigrina (Gmel.). 38. Cape Mav Warbler.}

Synonyms: Dendrœca tigrina, Perissoglossa tigrina, Sylvia maritima, Sylvicola maritima, Motacilli tigrina.

Kirtland, Ohio Geol. Surv., 1838, 163, 181.

The Lorain county records for this warbler number less than a dozen, all in the first week of May. There are no reports of any.greater number anywhere in the state in the spring migrations, but Rev. Mr. Henninger notes it as common during the autumn migrations in Scioto county, "especially in upland beech woods." It is strictly a migrant in the state, stopping but a short time in spring, but passing south more leisurely.

It reaches southern Ohio late in April, and northern Ohio a week later; returning about the middle of September, and may be found in Scioto county as late as October 3. 
24\%. (652.) Dendroica שstiva (Gmel.). 39. Yellow Warbler.

Synonyms: Dendrœca æstiva, Sylvicola æstiva, Sylvia æstiva, Motacilla æstiva.

Summer Warbler, Summer Yellowbird, Blue-eyed Yellow Warbler, Golden Warbler, Yellow-bird, Yellow-poll Warbler, Wild Canary.

Kirtland, Ohio Geol. Surv., 1838, 163, 182.

This well-known warbler is our commonest summer warbler in all parts of the state. It has the capacity of accommodating itself to almost any conditions, seeming as much at home in the orchard or ornamental trees as in its primitive briar tangle in some drying swamp. Its nest may be within a few feet of the ground or in the tree-tops if necessary. As an inhabitant of the orchards it is kept busy with the insect pests which make the life of the fruit-grower miserable. Here it is a great aid in keeping in check fruit destroying insects.

The Yellow Warbler is among the earlier warblers to appear in spring, reaching our southern border before the 20th of April, or even during the first week of April, in favorable years. It is usually found at Oberlin about the $22 \mathrm{~d}$ of April, often earlier. The departure in the autumn is not so easy to trace. I have found them in Oberlin as late as September \%. It is likely that individuals remain much later but the majority have gone before the first of September.

\section{8. (654.) Dendroica Cereulescens (Gmel.). 40. Black-throated Blue Warbler.}

Synonyms: Dendrœca cærulescens, Sylvia canadensis, Sylvicola canadensis, Dendroica canadensis, Motacilla canadensis, M. cærulescens.

Canadian Warbler, Pine Swamp Warbler. Kirtland, Ohio Geol. Surv., 1838, 163, 182.

This is one of the fairly common migrants, passing entirely across the state twice each year. It is as often seen in parks and along shaded streets in spring as in the woods, but seems to avoid human habitations on its return journey. It is an inhabitant of the lower stories of the woods, even 
feeding upon the ground, when the white wing-spot is conspicuous against the blue-black wing.

It reaches southern Ohio as early as the 15th of April in favorable years, but seldom appears at Oberlin before the first of May. It remains about two weeks, and returns again early in September or even late in August, to remain until about the first of October.

\section{9. (655.) Dendroica coronata (Linn.). 41. Myrtle Warbler.}

Synonyms: Dendrœea coronata, Sylvia coronata, Sylvicola coronata, Motacilla coronata.

Yellow-rumped Warbler, Yellow-crowned Warbler, Yellowrump, Myrtlebird, Yellow-rumped Wood Warbler.

Kirtland, Ohio Geol. Surv., 1838, 163, 181.

This is an irregular warbler, sometimes being abundant and again hardly even common. It is the carliest to appear in spring and the latest to depart southward in autumn. It does not breed in the state as far as known. In its northward movement it is well distributed in the woods and parks, but in its southward journey it prefers to travel in the more open country, often with the Chipping Sparrow. At such times it may be seen in the fields gleaning among the weeds like a sparrow, or searching for insects in weed stems. It derives its name from its fondness for the berries of the myrtle (Myrica cerifera).

During the spring passage of this species the insect food is greatly in the preponderance, although even then myrtle berries are eaten when they can be found, but during the autumn passage southward, when the fruit of the myrtle is abundant, it has been determined that fully 62 per cent. of the food is the myrtle berries. It seems remarkable that a bird supposed to be an insect eater should feed so largely upon this particular fruit. The myrtle berries are good for nothing, while the insects eaten are injurious. It is clear that this warbler deserves protection equally with the other warblers.

The Myrtle Warbler appears in Lorain county about the 
middle of April, depending on the weather at that time, and tarries until the middle of May, or later sometimes. It returns late in September and is fairly common until the 20th of October, scattering individuals remaining into the first week of Novenber.

\section{0. (65\%.) Dendroica maculosa (Gmel.). 42. Magnolia Warbler.}

Synonyms: Dendrœca maculosa, Sylvia magnolia, S. maculosa, Sylvicola maculosa, Motacilla maculosa.

Black and Yellow Warbler.

Wilson, Am. Orn., III, 1811, 63.

Dr. Wheaton says of this species, "Ábundant and regular spring and fall migrant in middle Ohio, summer resident in small numbers in north-eastern Ohio." At the present time it is generally regarded as not common as a migrant, except occasionally, when it becomes common. I find no evidence that this warbler now breeds within the state. While few of us find the first warblers on their return in late July or early August, it is well known that they migrate as early as that. Middle of the summer specimens do not, therefore, indicate that the birds have bred in the vicinity. Late June records would more likely indicate breeding birds.

The Magnolia Warbler reaches northern Ohio early in May, and the last has passed north about May 21. It returns late in July or early in August, judging from the records, and remains until about September 20 .

251. (658.) Dendroica Rara Wils. 43. Cerulean Warbler.

Synonyms: Dendrœca cærulea, Sylvia azurea, S. rara, Dendroica cærulea.

Azure Warbler, Blue Warbler.

Kirtland, Ohio Geol. Surv., 1838, 163, 182.

Dr. Wheaton's statement, "Abundant summer resident," no longer applies to this woods-haunting warbler. It is universally reported as not common during the summer. It would be hard to assign a reason for this decrease in num- 
bers, since the places where the bird now nests are numerous enough for its purposes. True, it does not go out of the taller woods to breed, but it seems to find woods enough suitable for breeding places. It may be, however, that during the earlier days it was confined to the deeper woods and the rapid disappearance of them has driven many to other regions. In Lorain county it is to be found in every consiclerable woods, but is only common here.

The Cerulean Warbler arrives with the warbler host, about the first of May in northern Ohio, and is fairly common for two weeks. The departure northward of a majority of the individuals leaves the state thinly settled with Ceruleans. It passes south during the last week of September.

252. (65̃.) Dendroica pensylvanica (Linn.). 44. Chestnut- sided Warbler.

Synonyms: Dendrœca pennsylvanica, Sylvia icterocephala, Sylvicola icterocephala, Motacilla pennsylvanica, M. icterocephala.

Quebec Warbler, Yellow-crowned Warbler.

Kirtland, Ohio Geol. Surv., 1838, 163, 181.

Of all the warbler host this is to me the most interesting, in its parti-colored dress and confiding ways. The day that brings them is the brightest day of the season. In their northward movement they are not particular about the places where they feed, provided the insects are numerous and the trees are not too far apart. Every year we see numbers of them on the College Campus. I have seen them in the dooryard, in the apple-trees, and in the deep woods among the highest branches. It is common only locally, apparently. Dr. Wheaton gives it as a summer resident in the north-eastern parts of the state. It is not unlikely that it still breeds in the northern part of the state, but if so it has not been so reported to me. None have been found in summer in Lorain county.

This is one of the warbler host which reaches Oberlin about the first of May, remaining about two weeks and then 
passing north. It returns early in September and remains until the last week of the month.

253. (660.) Dendroica castanea (Wils.). 45. Bay-breasted Warbler.

Synonyms: Dendrœca castanea, Sylvia castanea, Sylvicola castanea.

Bay-breast.

Kirtland, Ohio Geol. Surv., 1838, 163, 181.

Apparently this warbler is not well enough known to make any statements of its spring migrations reliable. - In Lorain county it is fairly common every spring, and usually more numerous in the autumn. That seems to be the general verdict, except that in many places the species is not at all common. The whole warbler group is perhaps less known by the average bird student than any other. The reason for this lack of acquaintance is not easy to explain, because the usually bright patchy coloring of these birds makes them somewhat conspicuous. Their small size and arboreal habits, and the difficulty of detecting them among the foliage, doutbless contribute largely to the difficulties.

This is among the later arrivals in spring, not appearing in Lorain county before May 5, generally, and has gone northward by the $23 \mathrm{~d}$. In its southward migrations it reaches Ohio about the middle of August, and tarries in the southern counties until the middle of October.

254. (661.) Dendroica striata (Forst.). 46. Black-poll Warbler.

Synonyms: Dendrœca striata, Sylvia striata, Sylvicola. striata, Muscicapa striata.

Black-poll.

Kirtland, Ohio Geol. Surv., 1838, 163, 182.

This warbler arrives even a little later in spring than the Bay-breast, and is frequently associated with it. Judging from the reports it is a little more numerous in spring and fully so in the autumn. Fall specimens of these two warblers are so nearly alike that one not well acquainted with 
them will probably not be able to distinguish between them in life. A good pair of field glasses, such as the 8-power prism glasses, usually makes their identification possible at a range of twenty-five yards. But under any circumstances close scrutiny is necessary to detect the tint of creambuff on the underparts of the Bay-breast and the distinctly yellow tint of the same parts of Black-poll. Both species are wood birds, but they also feed in wooded parks within the city limits, at times. In their southward migrations they are partial to the hillsides bordering streams where the trees are not so tall.

The Black-poll does not reach Oberlin until after May 10 , and remains but a week or ten days. It returns during the last half of August and does not leave our southern border before the 10 th of October.

\section{5. (662.) Dendroica blackburnie (Gmel.). $4 \%$. Blackburnian Warbler.}

Synonyms: Dendrœca blackburniæ, Sylvia blackburniæ, Sylvicola blackburniæ, Motacilla blackburniæ.

Hemlock Warbler, Orange-throated Warbler.

Kirtland, Ohio Geol. Surv., 1838, 163, 181.

Dr. Wheaton regarded this beautiful warbler as an abundant migrant. It appears to have decreased in numbers until it is only common in most parts of the state, and uncommon in others. At Oberlin it is usually common during both migration periods. It is a bird of the tree-tops, seldom descending below the middle story of the woods, unless the weather be inclement. It is one of the few birds which attract the attention of the casual passer whose eyes are ever raised above the ground. Its brilliant orange throat gleams like a sunbeam amid the foliage.

This winged Prometheus comes with the opening buds near May-day, usually after rather than before, and remains until the foliage hides him. During the first two weeks only males in brilliant dress may be found, but during the last week these have made way for the host of plainer colored females. The last are seen about May 22. The return 
may be as early as the middle of August, the last passing south about September 25.

256. (663a.) Dendroica dominica al.bilora Ridgw. 48. Sycamore Warbler.

Synonyms: Dendrœca dominica var. albilora, Sylvia pensilis, Sylvicola pensilis, Dendroica superciliosa, D. dominica. White-browed Yellow-throated Warbler, White-cheeked Warbler.

Kirtland, Am. Journal Sci. \& Arts, XL, 1841, 21. The first reference for the subspecific name as it now stands should be Ridgway, Am. Nat., VII, 1873, 606.

This species appears to breed sparingly across the state, but is known by few observers. I have never seen it. Dr. Wheaton states that it is the earliest of all the warblers in spring, even preceding the Myrtle. If it has passed through Lorain county it has entirely eluded careful search for a half-dozen years. It certainly does not breed in the western half of the county or it would have been found at some time. It has actually been found breeding at Cleveland, Mt. Vernon, Wauseon, and Cincinnati. More careful search for this early warbler should reveal its presence in many parts of the state where it is not now known even as a migrant.

Reliable migration dates are wanting, but it appears that the birds should be looked for early in April, and that some remain in the southern counties well into October. Sycamore groves appear to be the favorite places for these birds.

25\%. (66\%) Dendroica virens (Gmel.). 49. Black-throated Green Warbler.

Synonyms: Dendrœca virens, Sylvia virens, Sylvicola virens, Motacilla virens.

Kirtland, Ohio Geol. Surv., 1838, 163, 181.

Unlike the two following species, this one is among our commonest migrant warblers. Dr. Wheaton's designation of "Abundant spring and fall migrant," still applies. It is common in the woods, but seems to prefer the lawns, parks, 
and shaded streets. At almost any hour of the day, during the first two weeks of May, several may be heard singing about the library building on the Oberlin College campus. It is no less numerous anywhere else in the state, judging from the reports.

In the spring migrations it reaches southern Ohio about April 25 and the lake shore about two days later; passing north about May 20, but often remaining several days longer, singing all the time. The first return during the latter part of August and tarry into the first week of October. It is just possible that a few pairs remain to breed in the northern counties.

\section{8. (670.) Dendroica kirtlandi Baird. 50. Kirtland Warbler.}

Synoryms: Dendrœca kirtlandi, Sylvicola kirtlandi. Baird, Ann. Lyc. N. Y., V. 1852, 217.

Our state enjoys the honor of furnishing the type specimen of this rare and little known species, and to Charles Pease belongs the coveted honor of securing that specimen. The state records should be brought down to date. The name of the collector, place and date are given.

Charles Pease, near Cleveland, May 13, 1851 (type).

R. K. Winslow, near Cleveland, June (May?), 1860.

Charles Dury, Cincinnati, first week in May, 1872.

W. and J. Hall, Rockport (Cuyahoga county), May, 1878.

H. E. Chubb, Cleveland, May 4, 1880.

H. E. Chubb, Cleveland, May 12, 1880.

L. S. Keyser, Springfield (?), 1891.

Lynds Jones, Oberlin, May 11, 1900.

Lynds Jones and W. L. Dawson, near Ironton, August 28, 1902 (two).

No other state can boast so many specimens, but Michigan is fast approaching us in numbers. Better acquaintance with the species and greater activity in field work will probably prove this supposably rare warbler not "The rarest of all the warblers." 


\section{9. (671.) Dendroica vigorsil (Aud.). 51. Pine Warbler.}

Synonyms: Dendrœca pinus, Sylvia pinus.

Pine-creeping Warbler, "Vigor's Vireo."

Wheaton, Ohio Agri. Report, 1860, 364 .

This is another of the almost ornithological mysteries to the writer. I have found just one specimen in Lorain county, and that one an early migrant. It is reported as a rare migrant by most persons, but is reported on good authority as breeding in the southern part of the state. Dr. Wheaton did not know of any record of its breeding. Beyond doubt it should be one of the breeding warblers of the state. It needs careful looking after by competent field observers everywhere.

Migration dates are meager, but they indicate that this warbler makes its appearance late in April, and departs about October 10 from the southern counties.

260. (672.) Dendroica palmarum (Gmel.). 52. Palm Warbler.

Synonyms: Dendrœea palmarum var. palmarum, Sylvia petechia, Sylvicola ruficapilla, Motacilla palmarum.

Red-poll Warbler, Red-poll.

Kirtland, Ohio Geol. Surv., 1838, 163.

The general verdict is that this warbler is not common as a migrant. In some regions it seems to be fairly common, and probably is sometimes so in most localities. It is a bird of the underbrush, mostly, and will not often be seen with the other warblers. It seems to be fond of feeding about and in old brush-piles in spring, and wanders along railroad tracks and fence rows during its southward migration.

The Palm Warbler reaches the state about May 22 and remains two weeks or more if conditions are favorable. It returns during the first week of September and remains about a month. 
261. (673.) Dendroica discolor (Vieill.). 53. Prairie Warbler.

Snyonyms: Dendrœca discolor, Sylvicola discolor, Sylvia discolor.

Red-backed Warbler, Parti-colored Warbler, Pasture Warbler, Wildwood Warbler.

Audubon, B. Am., II, 1841, 68.

This interesting little warbler is little known by Ohio ornithologists, who regard it as a rare migrant. There are two Lorain county records of single specimens which did not remain to breed. Dr. Wheaton states that it breeds in northern Ohio but is migratory in the southern half. It should be found breeding wherever it is found in the state, but its rarity makes any records notable. Rev. Mr. Henninger regarded the specimen taken in Scioto county on October 8,1894 , as accidental. It will be found in brushy pastures and shrubby clearings, not in the woods. It is usually so confiding that a near approach is easy. Its song will not fail to arrest the attention of any one who has an ear for strange sounds. This is a warbler which all should be watchful for during the early days of May.

Migration dates are almost entirely lacking, but it is likely that records will fall within the first five days of May, for the first appearance in spring, and somewhere near the first of October for the departure in autumn from the southern counties.

262. (6\%4.) Seiurus aurocapillus (Linn.). 54. Oven-bird.

Synonyms: Siurus auricapillus, Sylvia aurocapillus, Motacilla aurocapillus, Turdus aurocapillus.

Golden-crowned Thrush, Accentor, Golden-crowned Accentor, Golden-crowned Wag-tail Warbler, Wagtail, Land Kickup.

Kirtland, Ohio Geol. Surv., 1838, 163.

The Oven-bird is a common summer resident over the entire state, and may be abundant in suitable localities. It must have dark woods, preferably damp, but not swampy. In hilly regions it frequently nests well up on the hillside. 
Its oven-shaped nest is not readily seen among the dead leaves, of which the exterior is made. The crescendo chant is one of the characteristics of some woods. The bird's dress so hamonizes with the environment that the chant may well be considered a spirit chant coming from everywhere and nowhere. The birds seldom mount high in the trees, but remain near the ground, walking about as any civilized bird should.

The Oven-bird reaches Oberlin near the 24th of April, sings until July 10, rarely later, and leaves us for the south during the last week of September, sometimes later.

\section{3. (675.) Seiurus noveboracensis (Gmel.). 55. Water-Thrush.}

Synonyms: Siurus nævius, Sylvia noveboracensis, Turdus noveboracensis, Motacilla nævia, M. noveboracensis.

Water Wagtail, Water Thrush, Small-billed Water-Thrush, Bessy Kickup, River Pink, Aquatic Accentor, New York Aquatic Thrush.

Kirtland, Ohio, Geol. Surv., 1838, 163, 181 (part).

This warbler is hardly common in most sections of the state. It is sometimes almost so at Oberlin, for a few days in spring. Like the other members of this genus it is a lover of damp places, preferring those that are somewhat swampy, while with us. I have never seen it higher up in the trees than ten feet, and then only when it was greatly disturbed. Its wild ringing song is given from a low perch or from the ground. When being pursued the bird has a habit of darting off and returning behind the pursuer or silently running ahead several rods and fitting close to the ground to appear far at one side. The quest is a nervewearing one, but if once in a dozen times you see the bird a moment before he glides away that is reward enough. You don't wish to have all birds perch on your nose!

The Water-Thrush reaches Oberlin about the $3 \mathrm{~d}$ of May and passes north with the warbler host about May 22. It returns during the early days of September and remains until the 1st of October. 
264. (676.) Seiurus motacilla (Vieill.). 56.

Louisiana Water-Thrush.

Synonyms: Siurus motacilla, Sylvia noveboracensis, Turdus noveboracensis, Seirus ludovicianus, Turdus motacilla. Large-billed Water-Thrush, Large-billed Accentor, Water Wagtail, Large-billed Wagtail Warbler.

Kirtland, Ohio Geol. Surv., 1838; 163, 181 (part).

This is really the earliest of all the warbler group, but cloes not get the credit it deserves because its name is not warbler. I have found it at Oberlin the last of March. It is only locally common as a summer resident in the state; in most places it is not cummon, but can hardly be considered rare. In Lorain county it is pretty strictly confined to the deep stream gorges or to the hills and banks at the lake shore. Somewhere in every stream gorge a pair or more may be found during the summer. Of course the gorges must be wooded, and with a stream flowing at the bottom. This species prefers to remain on the ground, seldom perching in a tree unless disturbed about its nest or young. Its wild song echoes and reëchoes in the steep walled gorge, recalling the untamed spirit of the Red man whose hunting ground this once was.

The average dates of arrival for this species fall within the first week of April, for southern Ohio, and a week later for Lorain county. The last ones leave the state during the middle of October.

265. (67\%.) Geothlypis formosa (Wils.). 58. Kentucky Warbler.

Synonyms: Oporornis formosa, Sylvia formosa, Myiodioctes formosa,Sylvicola formosa.

Kentucky Yellow-throat.

Audubon, Orn. Biog., 1, 1831, 196.

Dr. Wheaton says of this warbler, "Rare summer resident; in particular localities only." It is now fairly common over most of the southern third of the state, and ranges nearly to the lake in the western half, and rarely to the lake in the 
eastern half of the state. There are three probable records of its occurrence in Lorain county.* In the rougher parts of the state this warbler is to be found in the gorges well grown with brush and trees. It seems partial to the steep hillsides in such localities.

The first appear in southern Ohio during late April or early May, and return south late in September.

\section{6. (678.) Geothly pis agilis (Wils.). $5 \%$. Connecticut Warbler.}

Synonyms: Oporornis agilis, Sylvia agilis, Trichas agilis. Kirtland, Ohio Geol. Surv., 1838, 162, 182.

This is one of the rare warblers which pass entirely across the state. Dr. Wheaton recorded five specimens taken in the state. The unquestionable records since 1882 are hardly more. But three have been recorded for Lorain county, one of them May 24, 1902. It must be looked for on or near the ground in brushy places, but not necessarily where it is wet. The birds are timid and retiring, but may be closely approached with care. I have never heard the song to know it.

The migrations appear to occur rather late in spring, and the return in fall is during the early part of August.

\section{7. (679.) Geothlypis philadelphia (Wils.). 59. Mourning Warbler.}

Synonyms: Sylvia philadelphia.

Philadelphia Warbler, Black-throated Ground Warbler. Wheaton, Ohio Agri. Report, 1860, 363, 373.

While this species seems to be more numerous than the last, it is by no means common anywhere in the state. It does not remain to breed, but passes north of our border. During their migrations these birds are to be found on or near the ground, rarely mounting into the lower branches of the trees. They seem to prefer brushy tangles within

* Since the above was written a specimen has been secured at Oberlip by the .writer. 
the woods, and have been found only in rather damp places in Lorain county. They are usually silent while here.

The individuals recorded at Oberlin have been among the latest arrivals-between the 10th and 15th of May. They remain but a week or ten days and then pass northward, returning early in August.

268
(681d.)
Geothly pis
TRICHAS
BRACHIDACTYLA
(Swain). 60.
Northern Yellow-throat.

Synonyms: Geothlypis trichas, Sylvia trichas, Trichas marylandica, Turdus trichas.

Yellow-throated Ground Warbler, Ground Warbler, Blackmasked Ground Warbler, Black-cheeked Ground Warbler, Black-necked Yellow-throat, Briar Wren, Yellow Briar Wren, Maryland Yellow-throat.

Kirtland, Ohio Geol. Surv., 1838, 163, 182.

This little brush warbler is everywhere common, and locally abundant in Ohio. It will be found in the brushy woods, weed-grown swales, or sloughs, in second-growth slashings, or in the fringe of brush surrounding high woods. In general it prefers damp situations, but may nest almost anywhere if the conditions are suitable for a nest. No doubt there are places in the hilly south-eastern parts of the state where this bird is rare if present, because the conditions which entice him are wanting.

The Northern Yellow-throat reaches Ohio during the last week in April and is soon common even to the northern counties. It sings during its entire stay, leaving the state early in October.

269.

$$
\begin{aligned}
& \text { (683.) ICTERIA viRENS (Linn.). } 61 . \\
& \text { Yellow-breasted Chat. }
\end{aligned}
$$

Synonyms: Icteria viridis, Turdus virens, Muscicapa viridis.

Yellow Mockingbird.

Audubon, Orn. Biog., II, 1834, 223.

This large unwarbler-like warbler is far more common in the southern counties than at the lake shore. Apparently the gradation is a nearly uniform one from the Ohio 
river to Lake Erie. It is locally abundant in the southern counties and is almost rare in the northern, except locally, where it may become fairly common. This is another thicket loving bird, and is found in nearly the same situations as the Maryland Yellow-throat, but in the smaller growth of trees. The birds live higher up, and usually nest higher; but, like the Yellow-throats, they must have brushy conditions, at least.

The Chat reaches Oberlin about the first of May and tarries until the first week of September.

(684.) Wilsonia mitrata (Gmel.). 62. Hooded Warbler.

Synonyms: Myiodioctes mitratus, Sylvania mitrata, Motacilla mitrata.

Hooded Fly-catchïng Warbler, Mitred Warbler, Black-headed Warbler, Selby's Warbler.

Read, Fam. Visitor, III, 1853, 367.

The summer distribution of this warbler is somewhat peculiar. In general it is more common southerly than northerly, but about Jefferson it is almost common. It is reported as rare during the summer near Cleveland. There is but a single record for Lorain county, and that was not a breeding bird.* It is certain that the species would have been found if it breeds in the vicinity of Oberlin. Even in the southern counties it is only locally common.

The Hooded Warbler frequents the undergrowth of the woods, but often mounts high up among the branches to sing. Its nest is in the undergrowth. In my experience the preferred nesting-place is in some rather flat woods among the spice bushes or other shrubbery which grows well under tall trees.

The migration records are somewhat uncertain, but seem to be during the first week of May and the last week of September.

* Since the above was written another specimen has been found at Oberlin. 
271. (685.) Wilsonia pusilla (Wils.). 63. Wilson' Warbler.

Synonyms: Myiodioctes pusillus, Sylvia wilsonii, Muscicapa pusilla.

Green Black-capped Fly-catching Warbler, Green Black-capped Yellow Warbler, Wilson's Black-cap, Black-capped Yellow Warbler.

Kirtland, Ohio Geol. Surv., 1838, 163, 182.

Wilson Warbler is strictly migratory, passing completely across the state both spring and autumn. Dr. Wheaton said of it, "Not common migrant in spring; abundant in fall." I have never found it common at Oberlin in spring, and even less numerous in fall. Its numbers appear to have decreased since Dr. Wheaton's time. It may be found in the shrubbery of woods, or even well up in the trees, when migrating. I have found it in orchards not infrequently, in company with the other migrating host of warblers.

This warbler is usually rather late in putting in an appearance, but the fact that it is sometimes recorded late in April argues that it may well be placed with the group of warblers which arrive about May 1 . It passes north about May 20, and returns early in August, to remain three weeks or more.

\section{2. (686.) Wilsonia Canadensis (Linn.). 64. Canadian Warbler.}

Synonyms: Myiodioctes canadensis, Sylvia pardalina, Sylvicola pardalina, Muscicapa canadensis.

Canada Fly-catching Warbler, Canadian Fly-catching Warbler, Speckled Canada Warbler, Necklaced Warbler, Canada Flycatcher.

Kirtland, Ohio Geol. Surv., 1838, 163, 181.

The Canadian Warbler should be found as a migrant anywhere in the state, both spring and autumn. It is not as numerous as many species, but is certain to be seen during each migration if one be on the lookout for it. I have found it more frequently in the higher woods than elsewhere, but it also feeds in the shade trees and orchards. In the woods it prefers the middle stories of the trees. 
At Oberlin this warbler makes its appearance about May 7 , remaining until about the 20 th. It returns early in August and individuals may be found as late as September 25.

273. (68\%.) Setophaga Ruticilla (Linn.). 65. American Redstart.

Synonyms: Muscicapa ruticilla.

Redstart, Redstart. Warbler, Redstart Flycatcher. Kirtland, Ohio Geol. Surv., 1838, 163.

Redstart is a common summer resident everywhere in the state, and in many localities is really abundant. It is partial to woods which contain many small trees among the larger timber. I have never found it nesting in deep woods devoid of underbrush or some small growth, but it is usually numerous in small second-growth timber.

It reaches the state during the last week in April, and has passed to the lake shore by the 1st of May. None are seen in Lorain county after September 25, but a few individuals may tarry in southern Ohio until the middle of October.

\section{Family MOTACILLIDÆ. Wagtails.}

The single species which inhabits Ohio is generally found in flocks in the spring and fall months, and may linger into the winter in the middle and southern parts of the state. Its usually small numbers make it unimportant economically.

2\%. (69\%.). Anthus pensilvanicus (Lath.). $2 \%$. American Pipit.

Synonyms: Anthus ludovicianus, A. spinsletta, Alauda pensilvanica.

Brown Lark, Titlark, Pipit, Louisiana Pipit, American Titlark, Wagtail, Prairie Titlark, Reddish-brown Titlark, Louisiana Lark, Hudsonian Wagtail. Kirtland, Ohio Geol. Surv., 1838, 163, 182.

The Pipit is so erratic in its movements that one is at a loss what to say about it. It is hardly common for more than a few days at a time, if a flock be regarded as an indi- 
vidual. The most of my dates of first appearance fall within the first week of May, but there is one record for March 15, 1901. The last have gone north by May 20. I have but one autumn record, which is October 19, 1896.

While the Pipit is a bird of the fields it may also perch in trees, and in that particular differs from the Horned Larks, which it somewhat closely resembles in general habits and appearance. The slight wag to the tail is always a good field mark.

From the habits and haunts of these birds one would conclude that their chief food must be the larvæ of insects, with perhaps a good deal of weed seed or grain of one sort or another. They are fond of searching over newly plowed fields, where they may be seen feeding.

Family TROGLODYTID王. Mockers, Thrashers, Wrens.

This family is so varied that it seems best to subdivide it into the two subfamilies.

Subfamily MIMINÆ. Mockers, Catbirds, Thrashers.

To this subfamily belong the larger birds which are nearly the size of the Robin. Three species occur in Ohio, one of them rarely, while the other two are common enough to be well known. The Catbird is the familiar slate-colored bird of the brushy tangles of the woods or garden, while the Brown Thrasher is more often seen along hedgerows where it nests. All members of this subfamily are famous singers and mockers.

275. (703.) Mimus polyglottos (Linn.). \%. Mockingbird.

Synonyms: Turdus polyglottus.

Mocking Thrush, Mimic Thrush.

Kirtland, Ohio Geol. Surv., 1838, 163, 181.

As an Ohio bird the Mockingbird is certainly rare. The unquestioned records seem to be as follows: Cincinnati, Langdon, Dury; Waverly, Henninger; Perry, Beeman; 
Morgan, Morris, Arrick, Davie; Oberlin, Jump (specimen); Columbus, Wheaton, Davie. The Cleveland records need confirmation. In Morgan county they were present all summer in 1896, and in the autumn of that year twenty birds were to be found. The same colony returned in 1897 but left during the cold May and June of that year, and have not been found since. There are a number of unconfirmed records of the Mockingbird from northern Ohio which may prove to be good records. But the likelihood of the presence of escaped cage-birds in the vicinity of cities, from which these reports come, throws some doubt upon the records.

Since the above was written Mr. C. H. Morris writes me that on January 25, 1903, in company with Mr E. J. Arrick, he found and captured a Mockingbird near McConnellsville. Let us hope that this is an indication of an invasion of this beautiful singer and mimic.

276. (\%04.) Galeoscoptes carolinensis (Linn.). 8. Catbird.

Synonyms: Mimus carolinensis, Turdus felivox, Mimus felivox, Muscicapa carolinensis.

Cat Flycatcher, Merle Catbird, Chat.

Kirtland, Ohio, Geol. Surv., 1838, 163.

Catbird is everywhere common during the summer, and abundant in many localities. It is probably too well known to make necessary the mention of its brush-loving proclivities. It is bold enough to make its summer home in the door-yard if a suitable nesting-place be furnished.

Forty-four per cent. of the Catbird's food consists of insects, and 56 per cent. vegetable matter. Of this 56 per cent. only one-third consists of fruit which might be cultivated. In most parts of Ohio it is certain that a large part of the fruit eaten is wild fruit. Hence the Catbird is really a decidedly beneficial bird. It cannot be denied that he eats some fruit on occasion, and may be punished for it. $\mathrm{He}$ is neither a witch nor a wizard, as many persons seem to think, but a plain everyday sort of bird, mostly concerned with his own business, wanting nothing only to be let alone. 
The Catbird reaches the state shortly after April 20, rarely earlier, and soon becomes common. The bulk of the species has gone south by the 10th of September, but individuals may remain well into October.

27\%. (705.) Toxostoma Rufum (Linn.). 9.

Brown Thrasher.

Synonyms: Harporhynchus rufus, Turdus rufus, Mimus rufus. Brown Thrush, Thrasher, Sand Mockingbird, French Mockingbird, Ferrugineous Thrush, Fox-colored Mockbird.

Kirtland, Ohio, Geol. Surv., 1838163.

Although fairly common, the Brown Thrasher is far less numerous than its cousin, the Catbird. It is a great lover of hedgerows and overgrown line fences where narrow thickets have formed. It may also be found in brushy tangles, but not in woods proper.

Sixty-four per cent. of what the Brown Thrasher eats is animal matter, mostly injurious insects, while only 36 per cent. is vegetable. This bird also eats fruit in its season, but the bulk of its vegetable food is of no use to man. It is one of the distinctly beneficial species which sometimes does some damage.

Contrary to what we might expect, this bird is an early April arrival from the south, rarely appearing late in March. The late snow-storms do not seem to inconvenience it. Individuals may be found during the first week in October.

Subfamily Troglodytine. Wrens.

Six species of wrens are found in Ohio. In the north the House, and in the south Carolina and Bewick are familiar about dwellings. The two Marsh Wrens have spoiled their voices by living so much in the damp of the marshes, but the other members of the group are good singers. The tireless energy of these birds makes the classical ant look to his laurels. We have nothing but commendation for the services rendered by these birds, even if they do occasionally usurp the dwellings of other birds. 
278. (718.) Thryothorus ludovicianus (Lath.). 21. Carolina Wren.

Synonyms: Troglodytes ludovicianus, Sylvia ludoviciana.

Great Carolina Wren; Mocking Wren, Louisiana Wren, Hammock or Hummock Wren, Palmetto Wren, Large Wood Wren.

Kirtland, Ohio Geol. Surv., 1838, 168, 183.

Dr. Wheaton's statement, "Abundant in Southern, common and resident in Middle, rare in Northern Ohio," still holds good in the main. There is good evidence that its northern range is extending, and that the birds are becoming more common north than he knew them. They seem to be resident wherever they occur. We found them on East Sister Island, Lake Erie, and there are records even into Ontario.

In many places this wren is as familiar as the House Wren, building under the porch roof. It is fond of brushy tangles and bushy ravines or gorges. The borders of streams afford good cover.

The food of this wren is almost entirely animal, and the most of that insects. It is likely that in winter more vegetable waste may be eaten if other food is hard to secure, but at any time this large wren is one of the most beneficial of our birds.

279. (719.) Thryomanes bewickil (Aud.). 22. Bewick Wren.

Synonyms: Thryothorous bewickii, T. b. var. bewickii, Troglodytes bewickii.

Southern House Wren, Long-tailed House Wren, Song Wren, Long-tailed Wren.

Dury and Freeman, Journal Cin. Soc. Nat. Hist., II, 1879, 101.

While Dr. Wheaton and Dr. Langdon admitted this wren to their earlier lists they removed it from their later ones because the records upon whici statements were made proved unfounded. The above reference is the first authentic record.

It appears that this wren, which was unknown as an Ohio bird in 1882, has extended its range northeastward almost 
if not quite to our northern border as far east as Oberlin, where it has twice been recorded within the last five years. It is gradually but surely replacing the House Wren in the southern counties, possibly because it is the resident form while the House Wren migrates. It is common now as far east as Scioto county, and nearly as far north as Columbus.

The food of this wren does not differ materially from that of the Carolina Wren. It is distinctly beneficial in its food habits.

280. (721.) Troglodytes aedon Vieill. 23. House Wren.

Synonyms: Trogoldytes domesticus, Motacilla domestica.

Eastern House Wren, Short-tailed House Wren, Wood Wren. Read, Proc. Phil. Acad. Nat. Sci., VI, 1853, 396.

The House Wren, once a common summer resident in all parts of the state, is now being forced out by the invasion of Bewick Wren. It does not appear to be increasing in those parts of the state not yet covered by the last species, but is holding its own there. I have been disappointed in not finding more House Wrens about the houses. The woods are much more preferred in Ohio than in the central parts of Iowa. In certain parts of every town this wren may be found, but it is not present everywhere that a place offers.

The food consists almost wholly of insects that harm fruit-trees. It has lately been discovered that if a pair of House Wrens are driven from a box or other nestingplace which they have selected, and are permitted to nest in the vicinity, they will destroy the eggs of any birds which may nest in that place desired by them but denied them. One would not suppose vindictivenesss to be a vice of Jenny Wren.

The House Wrens appear in southern Ohio about the middle of April, and a week later at Oberlin. They return south about October 1. 


\section{1. (722.) Olbiorchilus hiemalis (Vieill.). 24.} Winter Wren.

Synonyms: Anorthura troglodytes var. hyemalis, Troglodytes europæus, T. hyemalis, T. parvulus var. hyemalis, Sylvia troglodytes.

Bunty Wren.

Kirtland, Ohio Geol. Surv., 1838, 163.

Dr. Wheaton stated that this little wren is a common winter resident. It is now not at all common in most localities. Possibly its small size and lowly habits cause it to be overlooked. It is more numerous during the migrations, in Lorain county, than during the winter, arguing that the majority of individuals pass farther south to winter.

During the winter it haunts brush-piles, where it is able to pick up a respectable living of animal matter, and the stream gorges, probably passing the nights in the little caves in the rocks.

Individuals may be found as late as May 10, in spring. I have never found one before the 10th of October in autumn.

\section{2. (724.) Cistothorus Stellaris (Licht.). 26. Short-billed Marsh Wren.}

Synonyms: Troglodytes brevirostris, Troglodytes stellaris.

Fresh Water Marsh Wren, Meadow Wren.

Read, Proc. Phil. Acad. Nat. Sci., VI, 1853, 395.

This is a rare bird in Ohio. It appears to breed in suitable localities anywhere in the state, but is too rare to be noticed by any but the ornithologist who is on the lookout for it. There are two Lorain county records, but neither of them of breeding birds.

Unlike the next species, this wren does not prefer the large marshes, but rather wet lands which have a rank growth of coarse grass. Here the birds build their mouselike nest, lashing it to the grass stems. I have never seen the birds in brushy places, nor in the immediate vicinity of true marshes.

The food differs from that of the more arboreal wrens only in the kinds of insects eaten. 
Its Ohio migrations cannot be accurately given because we have no data. It is likely that the birds reach Ohio during the first ten days of May, and depart southward again during the middle of September.

283. (725.) Telmatodytes Palustris (Wils.). 25.
Long-billed Marsh Wren.

Synonyms: Cistothorus palustris, Troglodytes palustris, Motacilla palustris, Certhia palustris.

Salt-water Marsh Wren, Marsh Wren.

Kirtland, Ohio Geol. Surv., 1838, 163.

This Marsh Wren is abundant about most of our large marshes. Regions without marshes or marshy conditions will not be visited by this species. I found them literally swarming at Licking and Lewiston reservoirs, Sandusky Bay marshes and Chippewa Lake. A few pairs remain in the rapidly narrowing marshes at Lorain and Oak Point.

These birds are true swamp birds, lashing their nests to reeds and cat-tails which stand in the water. In my mind they are associated with Coot, Florida Gallinule, and Black Tern.

The food is largely insects, and probably also some other small animals inhabiting such regions.

This wren reaches Lorain county during the first five days of May, and is gone by the middle of September.

\section{Family Certhidde. Creepers.}

284. (726.) Certhia familiaris americana (Bonap.). 20.

Brown Creeper.

Synonyms: Certhia familiaris, C. f. rufa, C. americana.

American Creeper, Little Brown Creeper.

Kirtland, Ohio Geol. Surv., 1838, 164.

The Brown Creeper is sometimes common during the migrations, but is less common as a winter resident over the entire state. His small size and weak voice and resemblance to the bark of trees serve to hide him from all but 
the inquiring eye. In winter he prefers the deep woods, though often found in towns; but during the migrations he frequently pursues his search for insects and larvæ in the bark of our shade trees. In winter I have usually found him among the company of nuthatches, woodpeckers, and titmice.

In spring he tarries well into May, returning late in September.

Family Parid s. Nuthatches and Titmice.

\section{Subfamily Sitrinæ. Nuthatches.}

The nuthatches are so different from all other birds in their manner of feeding that they attract attention at once. They much prefer to cling head downward on a perpendicular tree trunk, prying into the crevices of the bark, or "hatching" the kernel from some nut or seed. They always want to know what you are and what you propose to do about it. They are poor singers, but the voice is strong and carries far. The term "sapsucker" is wholly misapplied to these birds. They are wholly useful.

\section{5. (72\%.) Sitta Carolinensis Lath. $1 \%$.}

White-breasted Nuthatch.

Synonyms: White-bellied Nuthatch, Carolina Nuthatch. Kirtland, Ohio Geol. Surv., 1838, 164.

All must know this interesting inhabitant of the trees, for he is common all the year everywhere in the state, coming into the parks and not infrequently building his nest there or in the shade trees along the streets. He may be found everywhere that trees grow, especially in winter. He is usually the first of the winter company to make his presence known in the woods. His habit of clinging and feeding head down on the trunk of a tree attracts attention to him at once.

The food of this bird is both insects and vegetable matter. The insects are such as inhabit the bark of trees, most$1 \mathrm{y}$, and the vegetable matter seems to be largely the beech- 
nuts and the other small forest nuts and fruits. I have seen the nuthatch descend to the ground for weed seed and other tidbits which have fallen upon the snow. $\mathrm{He}$ also sometimes searches about the decaying stumps and about the roots of the trees. There is nothing in the statement that he is one of the "sapsuckers", and so injures trees. $\mathrm{He}$ is a very useful bird at all times.

286. (728.) Sitta canadensis Linn. 18.

Red-breasted Nuthatch.

Synonyms: Red-bellied Nuthatch, Canada Nuthatch. Kirtland, Ohio Geol. Surv., 1838, 164.

This nuthatch is usually less common than the preceding, and is not resident anywhere in the state. It is more common as a migrant both spring and autumn, but it winters in small numbers over the entire state, more numerously in the southwestern part. It is found in nearly the same situations as the White-breasted, and frequently ranges with it. Its food seems to be much the same.

In its migrations it reaches the state early in April and is gone north by the middle of May, returning again about the middle of September. Most have gone south again a month later, a few remaining all winter.

\section{Subfamily Parinæ. Titmice.}

Of the members of this group which live in Ohio one is southern, scarcely reaching even the middle of the state. The other two are among the most common winter birds, the Chickadee often feeding about our houses. The Tufted Titmouse not infrequently comes into town, especially during March and April, when he is calling lustily. A whistled imitation of their calls will almost invariably bring one or more within reach of your hand. They are not so much in evidence in summer because they are busy with household affairs then. 
28\%. (731.) BжOLOPHuS BICOLOR Linn. 14. Tufted Titmouse.

Synonyms: Lophophanes bicolor.

Crested Titmouse, Toupet Titmouse, Peter-peter, Sugarbird.

Kirtland, Ohio Geol. Surv., 1838, 164.

This Titmouse is common all the year over the entire state. Its loud voice and unwariness make it a familiar woodland object. It also ventures into town during the winter and early spring, but keeps mostly to the woods. In winter it forms one of the company of small birds which range through the timber.

Its food consists of both animal and vegetable matter. The animal food is largely insects and the vegetable weed seeds and small nuts. It is at all times a useful bird.

288. (735.) Parus atricapillus Linn. 15. Chickadee.

Synonyms: Black-capped Chickadee, Eastern Chickadee, Black-capped Titmouse, Black-cap. Kirtland, Ohio Geol. Surv., 1838, 164.

There is hardly a more familiar bird in the state than either this more northern Chickadee or the next species. It comes into the dooryard during the winter, looking for any chance crumb, or for the suet which you may have thrown out or tied to some convenient tree. It generally retires to the woods at nesting-time, and is little seen then, but a whistled imitation of the pe te call will usually bring an answer and the bird himself after a little. The Chickadee is one of the most inquisitive of birds, and can readily be taught to feed from one's hand. It is well worth while to take a little time to cultivate the acquaintance of the birds which are sure to visit your yard at some time during the winter, for once they find provisions put out for them they become regular visitors, and soon call other birds to the feast. A bone not too closely picked, tied to a tree or nailed to a board placed convenient to the window, will do very well. They are also fond of suet, and broken nut meats are eagerly taken. 
The food of this smaller titmouse is not unlike that of the Tufted. The Chickadee is probably a greater weed-seed destroyer.

289. (736.) Parus carolinengsis Aud. 16. Carolina Chickadee.

Synonyms: Parus atricapillus var. carolinensis.

Southern Chickadee, Carolina Titmouse.

Wheaton, Ohio Agri. Report, 1874, 562.

It is difficult to distinguish between the two Chickadees at -first, but one soon learns to note the smaller size of the Carolina. The notes and calls are also different, being higher pitched and more rapidly given than the Chickadee of the poets, and usually of more syllables.

The distribution of this Chickadee is not clearly worked out for Ohio. It is the more common form south, but does not appear to displace the other anywhere. The evidence seems to point to a more northerly distribution in the western part of the state, where it is known as far north as Columbus and Granville, but it seems to be absent from Morgan county and east of there. We need to study the chickadees more carefully before any definite statement can be made of the distribution of this form.

Family Sylvidde. Kinglets and Gnatcatchers.

Next to the hummingbirds these are the smallest of our native birds. They are strictly arboreal, but sometimes glean from the ground. In their passage north and south the kinglets feed plentifully in our orchards and shade trees, only the Gnatcatcher remaining to nest.

\section{Subfamily Regulinæ. Kinglets. -}

290. (748.) Regulus Satrapa Licht. 13.

Golden-crowned Kinglet.

Synonyms: Regulus cristatus, R. tricolor.

Golden-crested Kinglet, American Golden-crested Kinglet, Fiery-crowned Wren.

Kirtland, Ohio Geol. Surv., 1838, 163. 
This kinglet is common as a transient, but less common as a winter resident. It is sometimes even abundant during the migrations in certain localities. The kinglets are leaf and twig gleaners, but also make sallies after flying insects. They are to be found among the evergreen trees during the winter more often than elsewhere, but also frequent well protected brushy woods to feed. Their food seems to be wholly insects.

This kinglet goes north about the middle of April and returns again about the first of October.

291. (749.) Regulus calendula (Linn.). 12. Ruby-crowned Kinglet.

Synonyms: Motacilla calendula.

Ruby-crown, Ruby-crowned Wren, Ruby-crowned Warbler. Kirtland, Ohio Geol. Surv., 1838, 163, 183.

The Ruby-crowned Kinglet is rather more common during its migrations than the Golden-crowned, but it does not remain during the winter, nor is there any record of its breeding within the state. It is found in the same situations as the Golden-crowned, both appearing in our parks and orchards in spring and autumn. The Ruby-crowned has a louder voice than its cousin , and may be more readily found on that account. The food is the same as that of the other species.

This kinglet reaches Ohio/about the middle of April and remains four weeks, returning about October 1 and passing south in about three weeks.

Subfamily Polioptiline. Gnatcatchers.

292. (751.) Polipotila cæerulea (Linn.). 11. Blue-gray Gnatcatcher.

Synonyms: Sylvia cærulea, Sylvania cærulea, Motacilla cærulea.

Blue-gray Flycatcher, Little Blue-gray Flycatcher. Kirtland, Ohio Geol. Surv., 1838, 163.

The Gnatcatcher is a fairly common summer resident in many localities, but less common in others. It is found in 
brushy woods, nesting well up in the trees. It is so unwary that a near approach is easy, even if the birds do not come near to inspect you. The delicate little song carries well and must arrest the attention of the unobserving. As the name suggests, it feeds upon flying insects, but also gleans from leaves and branches.

One might expect so small and apparently delicate a bird to tarry in the south late, but it reaches Lorain county as early as the first week in April in favorable seasons. It apparently passes south again late in September, but autumn records are not wholly satisfactory.

Family Turdide. Thrushes, Robins, Bluebirds.

The Thrushes have been placed at the top of the bird branch because of their musical ability. It does not seem likely that they will remain there long, because their structure pretty clearly points to a lower place. But wherever they may finally rest in classification they will never cease to attract the earnest attention of all those who love good bird music. Added to this æsthetic value of the thrushes, there is their undoubted usefulness economically. For the most. part they are woods birds, but during the migrations most of them may be seen in the shade trees or in the back yards. which have been left bushy. Robin and Bluebird are too familiar to call for any remarks of mine. They need no. added encouragement to live with us, but with a little encouragement the Wood Thrush, that "Nightingale of America," may easily be induced to make its nest in the: back orchard, from whence he will give you a charming serenade twice each day during the summer season.

293 $(755$ $\mathrm{H}$ Hylocichla mustelina (Gmel.) 1. Wood Thrush.

Synonyms: Turdus mustelinus.

Wood Robin, Wood Nightingale, American Song Thrush, Song Thrush.

Kirtland, Ohio Geol. Surv., 1838, 163. 
The Wood Thrush is a common summer bird in all parts of the state. It announces its arrival with a burst of song, and may be heard singing well into August. Brushy woods or small second growth seem to be preferred for nesting-places. It is not so much a bird of thorny tangles as the Catbird, preferring a growth of young trees. Some make their way into the towns and villages, nesting in the orchards and berry patches in back lots. During the summer of 1902, a pair successfully reared a brood within five rods of the Chapel building on the Oberlin campus.

The food of this thrush is very largely such insects and worms as may be found on the ground among the leaves. It has not been accused of eating either fruit or garden vegetables. Its beautiful song adds to its usefulness a charm which every true bird lover cannot but wish to make a part of his summer life.

Wood Thrush comes to Ohio during the last days of April and remains well into September, but is silent during the last weeks of its stay.

294. (756.) Hylocichla fuscescens (Steph.). 2. Wilson Thrush.

Synonyms: Turdus fuscescens, T. wilsonii.

Veery, Tawny Thrush, Nightingale.

Kirtland, Ohio Geol. Surv., 1838, 163.

The Veery is much less common than the Wood Thrush, but during the migrations may be fairly common. Occasionally a few remain to breed even south to our southern border. In the northern tier of counties it is regularly found all summer, but in small numbers. Its vocal powers are of an entirely different order from the Wood Thrush, being rather weird than beautiful. It lives in close company with the Wood Thrush, apparently nesting in much the same localities. The food habits do not seem to be materially different.

Wilson Thrush is usually a few days later than the Wood Thrush, in spring, and departs a little earlier. 
295. (75\%.) Hylocichla aliciæ (Baird). 3.

Gray-cheeked Thrush.

Synonyms: Turdus swainsoni var. aliciæ, T. aliciæ.

Alice's Thrush.

Baird, Rev. N. Am. Birds, 1864, 23.

Dr. Wheaton records this thrush as a "Common spring and fall migrant." It has been universaily reported as a rare migrant. I have no doubt that closer acquaintance with it will prove it to be less rare. It is not easy to distinguish between this and the next species. I have found it only in the brushy woods in company with the Olive-backed. It appears to keep closer to the woods than the Olivebacked, feeding there on or near the ground. Its food probably consists of insects and worms largely.

Migration records are not satisfactory. Lorain county dates fall close to May 10, which is apparently near the end of the spring migration. I have no autumn dates.

\section{6. (758a.) Hylocichla swainsoni (Cab.). 4. Olive-backed Thrush.}

Synonyms: Turdus swainsoni.

Swainson's Thrush, Little Thrush, Swamp Robin.

Wheaton, Ohio Agri. Report, 1860 (1861), 379, hypothetical, Reprint, 5 .

"Abundant migrant" characterizes this species in a few localities, as it apparently did for Columbus, at least when Dr. Wheaton was working. At most localities it is only common. This thrush is often seen in the parks and shade trees during its migration, where I have seen it feeding upon the tender shoots of trees, probably the young buds of the elms. Rev. Mr. Henninger found it eating gum berries in September. Its food must consist of insects captured on the ground or in trees indifferently. I have often seen it making sallies after flying insects, much after the manner of the flycatchers.

This thrush appears at Oberlin during the last five days of April and has gone north by May 23. It returns early in September and tarries about four weeks. 
29\%. (759b.) Hylocichla guttata pallasil (Cab.). 5. Hermit Thrush.

Synonyms: Hylocichla unalascæ pallasi, Turdus pallasi, T. minor, T. solitarius, T. aonalaschkæ pallasii.

Solitary Thrush, Rufous-tailed Thrush, Eastern Hermit Thrush, Swamp Robin, Ground Swamp Robin.

Kirtland, Ohio Geol. Surv., 1838, 163.

This thrush must be looked for early in April or late in March, and for that reason may be overlooked by many students of the migrations. It remains in the deeper woods during its stay, and is usually silent. I have heard it sing on only one occasion. Dr. Langdon reports the breeding of this species in the vicinity of Cincinnati, on the authority of Mr. Charles Dury. It appears to be the only breeding record for the state.

The food habits do not seem to differ materially from those of the other thrushes, except that it is found earlier and does not venture into our parks and gardens.

As suggested above, this thrush arrives early in April, usually departing about the time the other thrushes arrive. It returns in October and is present but a short time.

\section{8. (761:) Merula migratoria (Linn.). 6. American Robin.}

Synonyms: Turdus migratorius.

Robin, Robin Redbreast, Migratory Thrush, Red-breasted Thrush.

Kirtland, Ohio Geol. Surv., 1838, 163.

Robin is a common resident in the southern counties, much less common in the middle parts and rare as a resident in the northern counties in favorable situations. As a summer resident it is abundant from the middle of the state north, but less so south. While a few individuals remain all winter well north it should be regarded as a spring arrival and summer resident there. During the breeding season it is to be found everywhere except in the deep woods and swamps. During the molting season it retires to the deep woods in some numbers, but many still remain about 
our lawns. It roosts at night with the blackbirds in considerable numbers, or forms roosts of its own.

The food of the Robin is varied according to the season largely. Prof. F. E. L. Beal has made a careful study of the food of this bird and it is worth while quoting extensively from his report here.

"An examination of 330 stomachs shows that over 42 per cent. of its food is animal matter, principally insects, while the remainder is made up largely of small fruits and berries. Over 19 per cent. consists of beetles, about one-third of which are useful ground beetles, taken mostly in spring and fall when other insects are scarce. Grasshoppers make up about one-tenth of the whole food, but in August comprise over 30 per cent. Caterpillars comprise about 6 per cent., while the rest of the animal food, about 7 per cent., is made up of various insects, with a few spiders, snails and angle worms. All the grasshoppers, caterpillars and bugs, with a large proportion of the beetles, are injurious, and it is safe to say that noxious insects comprise more than onethird of the Robin's food.

"Vegetable food forms nearly 58 per cent. of the stomach contents, over 47 per cent. being wild fruits, and only a little more than 4 per cent. being possibly cultivated varieties. Cultivated fruits amounting to about 25 per cent. were found in the stomachs in June and July, but only a trifle in August. Wild fruit, on the contrary, is eaten in every month, and comprises a staple food during half the year.

"The depredations of the Robin seem to be confined to the smaller and earlier fruits, and few, if any, complaints have been made against it on the score of eating apples, peaches, pears, grapes, or even late cherries."

From this it appears that the Robin is one of our most useful birds and should be rigidly protected.

The Robin is one of the first birds to greet us in spring and among the last to depart south. Dates of arrival for Oberlin fall very nearly on the first of March. The last are seen about the middle of November. A few remain all winter even on the lake shore. 
299. (766.) Sialia sialis (Linn.). 10. Bluebird.

Synonyms: Saxicola sialis, Sialia wilsonii, Motacilla sialis.

Eastern Bluebird, Blue Robin, Blue Redbreast, Blue Warbler, Cottage Warbler, Blue-backed Redbreast Warbler, Common Bluebird Wilson's Bluebird, American Bluebird. Kirtland, Ohio Geol. Surv., 1838, 163.

Bluebird is familiar to all who ever look at birds. Previous to that disastrous cold winter-1894-5-when the Bluebirds were all but exterminated in Kentucky and Tennessee, it was decidedly common all summer. Its recovery from that calamity has been steady and rapid until it has become common again. Previous to that time there were no records for its wintering in northern Ohio, but since then it is regularly found all winter in small numbers. The survivors were a hardier race which has pushed its range farther north. Bluebirds are found everywhere except in the deep woods during the breeding season. They easily adapt themselves to the changing conditions due to the settlement of the country, and readily breed in boxes erected for their use.

They feed to a small extent upon wild fruits and their seeds, but 76 per cent. of the food is animal, mostly noxious insects. There can be no question of the usefulness of Bluebird.

Robin and Bluebird arrive very near together, and tarry equally long into November. The Bluebird is considered the "Harbinger of Spring." 


\section{ACCIDENTAL.}

The species classed under this head are such as have wandered into the state from regions considerably removed which they regularly inhabit at some time of year. Their presence in the state cannot be accounted for in any other way than by supposing that some accident is responsible for their appearance in a place so far removed from their regular habitat, and therefore they cannot be expected to occur again under normal conditions.

\section{Order PYGOPODES. Diving Birds.}

Family Alcide. Auks, Murres, and Puffins.

The only representative of this salt-water inhabiting family is the Brünnich Murre, which was probably blown across Canada by a severe northeast storm. It is accidental in the state, and so would not figure in the economy of the state.

\section{1. (31.) Uria lomvia (Linn.). - Brünnich Murre.}

Butler, reported by E. L. Moseley as occurring at Sandusky on Lake Erie, Auk, 1897, 198.

The records that have come to me of the capture of specimens of this species in Ohio are: Ashtabula 1, Lake 2, Lorain 4, Erie 3, and likely Ottawa counties, all during the last half of December, 1896. Fairport, December 18; Sandusky, December 19. The Lorain and Ashtabula records are given as late December, probably about Christmas. It is not unlikely that individuals of this large inland flight penetrated to some of the interior waters of this state, but if so, records are lacking.

A wanderer from the northeast. 
Order TUBINARES. Tube-nosed Swimmers.

The order is represented by a single species, three individuals of which were probably blown inland by a severe southeast storm, reaching Cincinnati on the Ohio river. Being wholly accidental in the state, and unlikely to occur again except under similar conditions, the species does not figure economically.

Family Procellaridde. Petrels, etc.

\section{2. (98.) Estrelata hasitata (Kuhl.). - Black-capped Petrel.}

Synonym: Procellaria hasitata.

Lindahl, Auk, XVI, 1899, 75.

This reference may not be earlier than the Seventh Annual Report, Ohio State Academy Sciences, 56, same author, but absence of a specific date in that publication makes the above reference take precedence.

Two specimens were taken alive on October 5, 1898, on the Ohio shore, and one on October 4, the preceding day, on the Kentucky shore. All died in captivity and found their way into the collection of the Cin. Soc. Nat. Hist. All were in a starved condition, and therefore easily captured. Dr. Lindahl says that a severe northeast storm probably drove them inland.

Accidental from the east.

Order STEGANOPODES. Totipalmate Birds.

Family Fregatide. Man-o'-War Bird.

But a single specimen of the single species comprising this family has been taken in the state, reference to which is given under the species.

3. (128.) Fregata aQuila Linn. -

$$
\text { Man-o'-War Bird. }
$$

Synonyms: Pelecanus aquilus, Tachypetes aquilus.

Frigate, Frigate Pelican, Hurricane Bird.

Davie, Nests and Eggs of N. Am. Birds, 1898, 74. 
The single specimen for Ohio, according to Oliver Davie, in the above reference, "is now in the possession of Dr. Renshaw, of Sugar Grove, Ohio, and was taken by $\mathrm{Mr}$. Emmet Adcock, in Fairfield county, Ohio, in the spring of 1880."

Order ANSERES. Ducks, Geese, Swans.

Subfamily Anatinæ.

4. (136.) Mareca penelope (Linn.). Widgeon.

Synonyms: Anas penelope.

European Widgeon.

Jones, The Wilson Bulletin, 1902, 71.

The specimen here recorded was captured on the Licking reservoir, March 29, 1902, by Mr. Peter Hayden, of Columbus. The specimen was given to $\mathrm{Mr}$. Irving $\mathrm{A}$. Field who mounted it for the museum of Dennison University, Granville, Ohio, who reported this and another specimen captured there April 1.

Accidental from the east.

\section{5. (141.) Qurquedula cyanoptera (Vieill.). - Cinnamon Teal.}

Synonyms: Anas cyanoptera.

Davie, Nests and Eggs of N. Am. Birds, 1898, 81.

"On the 4th of April, 1895, a fine male of this species was killed ..... at the Licking county reservoir, by William Harlow." The specimen is now in Mr. Davie's private collection.

A wanderer from the west.

Order HERODIONES. Bitterns, Herons, Storks, Ibises, Egrets.

Suborder IBIDES. Spoonbills and Ibises.

Family IbIDIDE. Ibises. Ohio.

A single species of this family rarely wanders north to 


\section{6. (186.) Plegadis autumnalis (Hasselq.). 193. Glossy Ibis.}

Synonyms: Plegadis falcinellus, Ibis ordii, Ibis falcinellis, Ibis falcinellus var. ordii, Tringa autumnalis.

Black Snipe, Black Curlew.

Dr. Wheaton records the only specimen of this species which has ever been taken in Ohio, as follows: "Dr. Kirtland, after quoting from the Boston Traveler (June 28), 1850 , an account of the capture of this species at Cam:bridge and Middleboro, Massachusetts, and Middletown, Connecticut, says : 'To the above we would add that two of these interesting birds, probably a pair, were seen two years since near Fairport, Lake county. One of them, a beautiful male, was shot by Mr. Pruden, and forwarded to us. It was duly skinned and mounted, and may now be seen alongside of a Scarlet Ibis, from the banks of the Amazon, in the second case south of the door, in the cabinet of Nat. Hist., at Cleve. Med. Col." ",

A wanderer from the south.

Crisei PALUDICDL.玉. Cranes, Rails, etc.

Family rRUide. Cranes.

7. (205.) Grus canadensis (Linn.). -
Little Brown Crane.

Synonyms: Ardea canadensis.

Davie, Nests and Eggs of North American Birds, Fifth Edition, $1898,121$.

"I mounted a specimen of this bird which was taken in the spring of 1884, from a flock of seven or eight birds near Springfield, Ohio, It is a rare migrant in the state." This is the only state record, and must be regarded as strictly accidental. It is not given by Butler as a bird of Indiana, and is regarded as a doubtful species in northern Michigan.

A wanderer from the west. 
ORDER LIMICOL王. Shore Birds.

Family Scolopacide. Snipes, Sandpipers, etc.

8. (260.) Pavoncella pugnax (Linn.). [219.] Ruff.

Synonyms: Machetes pugnax, Trigna pugnax, Philomacus pug. nax.

Reeve, Combatant, Gambetta.

Wheaton, Bull. Nuttall Orn. Club, II, 1877, 83.

The above citation is of a specimen obtained by Dr. Theodore Jasper, at Licking reservoir, November 10, 1872. Rev. W. L. Dawson informs me that there is another specimen in the collection of the Ohio State Unvversity bearing date of April 28, 1878, taken at Columbus.

The credit for the preservation and final identification of the first specimen belongs to Dr. Wheaton.

A wanderer from the east.

Order RAPTORES. Birds of Prey.

Family Falconides. Hawks, etc.

9.(33\%b.) Buteo borealis calurus (Cass.). -

Western Red-tail.

Synonyms: Buteo calurus.

Black Red-tail.

A specimen in the collection of the Ohio State University proves to belong to this form. It was captured November 20, 18\%5, by Theodore Jasper, presumably near Columbus, since it is labeled “Franklin Co." in Dr. Jasper's handwriting. It is labeled a female.

ORDER PICI. Woodpeckers.

Family Picide.

10. (395.) Dryobates borealis (Vieill.). Red-cockaded Woodpecker.

Synonyms: Picus borealis.

Pine-bark Woodpecker. "Sapsucker." 
A specimen in the Ohio State University collection bears the following inscription: "Picus borealis. March 15, 1872. Loc. Columbus, O. It was in company with another of its own kind and 2 or 3 sapsuckers, nuthatches, etc., and shot from a high tree between the canal and Scioto river." It proves to be a typical specimen of this species.

Order PASSERES. Perching Birds.

Family Tyrannide. Flycatchers.

11. (443.) Muscivora forficata (Gmel.). Scissor-tailed Flycatcher.

Synonyms: Muscicapa forficata, Milvulus forficatus.

"Fork-tailed Flycatcher," Swallow-tailed Flycatcher.

Davie, Nests and Eggs of North American Birds, Fifth Edition, $1898,297$.

"A male specimen of the Scissor-tailed Flycatcher was taken near Marietta, O., May 20, 1894, by Mr. Frank H. Welder, the skin of which is now in his collection."

A wanderer from the southwest.

Family ICTERIDA. Blackbirds, etc.

12. (49\%.) Xanthocephalus Xanthocephalus

(Bonap.). [116.]

Yellow-headed Blackbird.

Synonyms: Xanthocephalus icterocephalus, Icterus xanthocephalus.

Wheaton, Ohio Agri. Report, 1874, 567. Mentioned by Coues, Birds N. W. as probable in Ohio.

There is a specimen in the collection of F. Frey, of Sandusky. A flock of six passed over Oberlin just above the treetops, October 9, 1896.

One is reported from McConnellsville, Morgan county, by Mr. E. J. Arrick.

These, with the statement of Dr. Wheaton that a pair was seen by Mr. W. R. Limpert, in the summer of 1873 , near Groveport, Franklin county, exhaust the Ohio records that I have been able to find.

A wanderer from the west. 
Family FringILlide. Sparrows, etc.

13. (553.) Zonotrichia Querula (Nutt.). Harris Sparrow.

Synonyms: Fringilla querula.

Hooded Crown Sparrow, Black-hood Sparrow. Davie, Nests and Eggs of N. Am. Birds, 1898, 337.

"On the 29th of April, 1889, Mr. J. E. Gould shot a specimen of Harris Sparrow two miles north of Columbus, Ohio. Four or five others were observed feeding in a thicket in company with the White-throated Sparrow, Z. albicollis." The specimen was presented to Mr. Davie, and his identification corroborated by Mr. C. F. Batchelder. The skin is now in the collection of the Ohio State University. This small group must have wandered far out of their way in the northward migration.

A wanderer from the west.

Family Mniotiltide. Wood Warblers.

14. (6\%2a.) Dendroica Palmarum hypochrysea

Ridgw. -

Y Yellow Palm Warbler.

McCormick, Auk, IX, 1892, 397.

This specimen, captured on April 10 (not 16 as in the Auk, 1892), remains the only record for the state. It was taken by Mr. G. D. Wilder, at Oberlin.

A wanderer from the east.

Family PARIDx. Titmice, etc.

15. (729.) Sitta Pusilla Lath.

Brown-headed Nuthatch.

Kirtland, Ohio Geol. Surv., 1838, 164, 183.

Dr. Kirtland's statement, "I once killed a specimen in the northern part of the state," remains the only instance of its occurrence within our limits. 


\section{INTRODUCED.}

Of the four species which have been introduced into Ohio but two are to be found now. The English Sparrow has become not only a nuisance, but a menace to the balance of nature between the insects and those birds which feed upon insects, by crowding the native birds out in many instances. It is not at all certain that the Mongolian or Ring-necked Pheasant may not, ere long, also prove a menace to the agricultural interests by a too great increase in numbers. Happily the other two foreign species were unable to gain a foothold in our state. They might not have proved injurious if they had succeeded in becoming acclimatized, but it is never safe to make predictions. Recent legislation forbids the importation of other birds and mammals into the United States except under proper supervision. It is not likely that we shall have to learn over again the folly of precipitate action of this sort.

\section{ORDER GALLINE.}

\section{Family Phasianide.}

1. Phasianus torguatus.

Ring-necked Pheasant.

Synonyms: Mongolian Pheasant.

Successfully introduced into Allen, Ashtabula, Crawford, Erie, Hamilton, Hardin, Madison, Morgan, Scioto, and Summit counties, and probably others.

\section{ORDER PASSERES.}

Family FringiLlide.

2. PASser domesticus (Linn.). [unnumbered.] English Sparrow.

Synonyms: Pyrgita domestica, Fringilla domestica.

European House Sparrow, Philip Sparrow, Parasite Gamin, Hoodlum, Tramp, The Sparrow.

Wheaton, Ohio Agri. Report, 1874, 566. 
The first importation of this pest into the state directly from Europe was into Cleveland, in 1869, twenty pairs. During the same year thirty-three pairs were taken from New York to Cincinnati and Warren. Then followed importations into Marietta, 18\%0, Coshocton and Portsmouth, 1874, Steubenville, about 1880 or 1881, Wapakoneta, about 1882, which seems to have been the last importation. Since that time it has spread well over the state, in the more settled districts, even invading the country places and farm buildings, until the tendency to nest in the woods grows strong. About Oberlin several pairs have already invaded the trees rightfully belonging to Bluebirds and Crested Flycatchers, in the woods a mile from the village.

\section{EXTINCT.}

But two native and two introduced species have become extinct in historic times. At least three others are rapidly approaching extinction: these are Wild Turkey, Passenger Pigeon, and Swallow-tailed Kite. It was supposed that these would prove extinct, but records of occurrence within the past ten years make it necessary to retain them for the present. The causes for the disappearance of these two native birds and the great decrease of the others are not far to seek. They have been mercilessly hunted and their natural breeding places have been destroyed in the settlement of the state. Lacking the ability to change their habits with the changing conditions, it was inevitable that they should die out.

Order GALLIN Æ.

Subfamily Tetraoninæ.

1. (305.) Tympanuchus americanus (Reich.). 183. Prairie Hen.

Synonyms: Cupidonia cupidio, C. americanus, Tetrao cupido. Pinnated Grouse, Prairie Chicken. 
The last trace I have been able to find of the presence of this bird in the state is that of Prof. E. L. Moseley, who reports a capture in 1880, near Sandusky. 'It is now extinct within the state.

.Apparently this bird has always been confined to the northwestern prairies of the state, and can hardly have been common at any time within the history of the state as a state.

\section{Order PSITTACI. Parrots.}

The single species representing this order in Ohio is now extinct in the state

Family Psittacide. Parrots and Paroquets.

\section{2. (382.) Conurus carolinensis (Linn.). Carolina Paroquet.}

Synonyms: Psittacus carolinensis.

Orange-headed Parrot, Carolina Parakeet, Carolina Parrot, Parakeet, Illinois Parrot.

Wilson, Am. Orn., IIJ, 1811, 89.

It is probably true that this almost extinct species was an inhabitant of the larger part of Ohio during the first decade of the 19 th century and previously, reaching Lake Erie at its western end at least. In 1831 Audubon remarked upon the rapid decline in numbers. Later than that the birds were largely confined to the southwest corner of the state, occurring in small and scattered flocks as far north as Summit county up to 1853 . "In July, 1862, a flock numbering from twenty-five to thirty made their appearance in the Capitol Square of Columbus," remaining a couple of hours in the elm trees in front of the residence of Wm. S. Sullivant, LL.D., who reported this occurrence to Dr. Wheaton.

Mr. Oliver Davie says: "The last record we have of this bird being taken in Ohio is October 9, 1884. A specimen was shot by Mr. A. Lee Hoskinson, near Newark, and mounted by S. G. Hamilton. . . . . It is still in Mr. Hoskin- 
son's possession." It is not impossible that this was an escaped cage-bird.

There can be no doubt that this belongs to the extinct species of the state.

\section{Order PASSERES. Perching Birds.}

Family Alaudide. Larks.

\section{3. (473.) Alauda arvensis Linn. [unnumbered] Skylark.}

Synonym: European Skylark.

Langdon, Journal Cin. Soc. Nat. Hist., I, 1878, 111.

The first attempt to introduce this European species into the state was by a Mr. Bateham in the autumn of 1851 , when a cage of them was liberated in the grove back of the Lunatic Asylum, Cincinnati. Colonel Harris stated that these shortly disappeared. Another more successful attempt seems to have been made during the seventies, since Dr. Langdon, in his list of 1878 , states that they had been found breeding in the outskirts of Cincinnati. This colony must have disappeared shortly after Dr. Langdon's list was published, for nothing more was known about them when Dr. Wheaton published his catalogue in 1882. Skylarks are unknown in the state now.

Family FringILlide. Sparrows, etc.

4. Carduelis carduelis (Linn.). -

Goldfinch.

Synonyms: Fringilla carduelis.

European Goldfinch, Thistlefinch.

Langdon, Journal Cin. Soc. Nat. Hist., IV, 1881, 342.

Introduced at Cincinnati during the years 1872-4. Apparently they did not thrive, since nothing has been heard from them since their introduction. 


\section{HYPOTHETICAL.}

The species included under this head are mostly those whose known range should cover Ohio either during their migrations or during their regular wanderings, but which have not yet been found in the state. Two of the species are here placed because they are regarded as hypothetical forms in the United States. The Cincinnati Warbler is still represented by a single specimen, and Brewster Warbler has not yet been given the distinction of a subspecific rank. It will probably be some time before the question of hybridism as applying to these two forms is settled. I have deemed it wise to place here some species included in Dr. Wheaton's catalogue on what appears now to be insufficient evidence. It is not enough to say that a species is or has been found; the statement must always be verified by specimens where the species is at all rare. No record should be allowed to stand unquestioned without the evidence of a specimen to prove that the species has occurred within the state.

\section{1. (38.) Stercorarius longicaudus Vieill. Long-tailed Jaeger.}

This Jaeger may pass across the state in its migrations.

\section{2. (40.) Rissa tridactyla (Linn.). 273. Kittiwake.}

Syronyms: Larus tridactylus.

こommon Kittiwake.

Wheaton, Ohio Agri. Report, 1860, 371, 379.

There are two records for Ohio. That of three specimens reported by Mr. R. K. Winslow in Cleveland harbor, clearly before the eighties, and the report of Mr. E. W. Vickers for Mahoning county. I am unable to find evidence of the preservation of specimens of this gull. The fact that it is regarded as rare or even doubtful as a winter visitor in Michigan, and has never been found in Indiana 
nor in Pennsylvania, throws doubt upon any record not accompanied by specimens.

3. (42.) Larus glaucus Brünn.

Glaucous Gull.

Arctic regions, south in winter to the Great Lakes and Long Island.

4. (65.) Sterna maxima Bodd.

Royal Tern.

Tropical America and warmer parts of North America, casually northward to Massachusetts, the Great Lakes and California.

5. (71.) Sterna Paradisea Brünn. Arctic Tern.

This tern should be found passing across the state during the migrations.

6. (120a.) Phalacrocorax dilophus floridanus (Aud.). 272a.

Florida Cormorant.

Synonyms: Graculus dilophus var. floridanus, G. floridanus, Phalacrocorax floridanus.

Water Turkey.

Wheaton, Ohio Agri. Report, 1874, 575.

The evidence that this form nested in considerable numbers at the St. Mary's reservoir prior to 1875 , is not beyond question.

7. (155.) Histrionicus histrionicus (Linn.). Harlequin Duck.

Synonyms: Anas histrionicus, Histrionicus torquatus.

Admitted to Dr. Wheaton's list in error. It may be found in the state. 
8. (166.) Oidemia Perspicillata (Linn.).
Surf Scoter.

Synonyms: Anas perspicillata.

It is likely to be found on Lake Erie.

9. (173.) Branta bernicla (Linn.). 246. Brant.

Synonyms: Bernicla brenta, Anser bernicla, Anas bernicla. Brant Goose.

Kirtland, Preliminary Report, Ohio Geol. Surv., 1838, 67.

The lack of specimens from Ohio necessitates placing this goose on the list of Hypothetical species.

\section{0. (191.1.) Ardetta neoxena Cory. Cory Least Bittern.}

If this be a good species it should be found in Ohio as a migrant and probably also breeding. It has been found breeding in Ontario, hence its migration route must cross Ohio.

11. (222.) Crymophilus fulicarus (Linn.). 226. Red Phalarope.

Synonyms: Phalaropus fulicaruis, Tringa fulicaria.

Coot-footed Tringa, Gray Phalarope.

Wheaton, Ohio Agri. Report, 1861, 380, hypothetical.

This published record is based upon the statement of $\mathrm{Mr}$. R. K. Winslow, of Cleveland, "that two or three specimens had been taken on Lake Erie." There being no other record, and no specimens preserved, it seems necessary to place the species in the Hypothetical list.

\section{2. (392.) Campephilus principalis (Linn.). Ivory-billed Woodpecker.}

Synonym: Picus principalis.

White-billed Logcock, White-billed Woodcock.

The evidence of the probable former presence of this regal woodpecker in Ohio is strong. A specimen was taken 
in Franklin county, Indiana, which borders Ohio. The map in the Auk, 1891, by Hasbrouck, illustrating the present and former range of this bird in the United States, is made to cover the extreme southwest corner of Ohio. We shall probably never have positive evidence of its occurrence in Ohio.

\section{3. (466a.) Empidomax traillii alnorum Brewst. Alder Flycatcher.}

Jones, Wilson Bulletin, No. 20, 1898, 37.

This subspecies was elaborated after Dr. Wheaton's time. While it has not been reported by any ornithologists in the state, there can be no reasonable doubt that it migrates across regularly. No doubt a critical examination of specimens in the local collections throughout the state will reveal specimens of this form now supposed to be traillii.

\section{4. (59\%.) Guiraca C⿸尹Rulea (Linn.). Blue Grosbeak.}

Reported at College Hill, Cincinnati, June 12, 1899, by Laura Gano. No specimen was secured. It seems likely that it may ocasionally reach our southwestern border.

\section{5. (601.) Cyanospiza ciris (Linn.). Painted Bunting.}

Reported from Sandusky by Prof. E. L. Moseley. No specimen was secured. This record, if authentic, would seem to be a case of escaped cage-bird. It is likely that wanderers may sometimes reach the vicinity of Cincinnati.

\section{6. (675a.) Seiurus Noveboracensis Notabil.IS (Ridgw.). \\ Grinnell Water-Thrush.}

Synonyms: Seiurus nævius notabilis.

Having been found at Brookville, Indiana, not far from our western border, it is entirely possible that it may be found in the western part of the state. 
17. (21.) Helminthopila leucobronchialis (Brewst.). Brewster Warbler.

Synonym: Helminthophaga leucobronchialis.

Jones, Wilson Bulletin, No. 42, June 15, 1903, 68.

On May 23, 1902, while out with my class for early morning study, we discovered a singing male of this interesting form. The first part of the song was clearly Blue-wing in all particulars, while the last was just as clearly Golden-wing. The students noticed the oddity of the song without having their attention especially called to it. We studied the bird in all lights and positions for half an hour, many times within fifty feet, with a pair of stereo-binoculars, clearly making out the white underparts, faintly tinted with yellow on the breast and a slight darkening of the chin feathers, the yellow crown and great yellow wing patch. On the 28th we again found the bird in the same situation, on the border of an open woods, and gave it even more attention than before. It was in full song, and seemed less wary than before. A week later it was gone. The evidence of nesting seemed so strong that I was unwilling to collect the bird, hoping to secure a breeding record and be able to study the hybrid family. The bird was probably not strictly typical leucobronchialis, but came near to it, as indicated by both song and plumage.

During the spring of 1903 two almost typical specimens have been secured and at least one other seems to be tarrying to nest in a woods half a mile west of Oberlin. I am hoping to add some direct testimony to the life history of this interesting variation.

18. (22.) Helminthopila cincinnatiensis (Langd.). 31.

Cincinnati Warbler.

Synonym. Helminthophaga cincinnatiensis.

Langdon, Journal Cin. Soc. Nat. Hist., III, 1880, 119.

The single specimen collected by Dr. Langdon, May 1, 1880, at Madisonville, from which his description was 
made, remains unique. In the absence of other specimens the theory of hybridism seems probable. If a hybrid it was probably between $H$. pinus and $G$. formosa. The formation of hybrids between $H$. pinus and some closely allied species seems not uncommon.

(371.) Nyctala tengmalmi Richardsoni (Bonap.). Richardson Owl.

Synonyms: Nyctale richardsoni.

Tengmalm's Owl, Arctic American Saw-whet Owl, American Sparrow Owl.

Coues, Birds of N. W., 1874, 314.

There seems to be no question but this reference was an error.

\section{SUMMARY.}

More or less regularly found in the state.............299

Accidental in the state.......................... 15

Imported from Europe.......................... 2

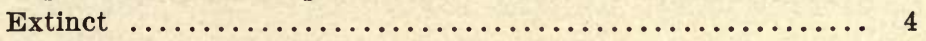

Hypothetical on the A. O. U. Check-List............. 2

Whole number of species actually recorded in the state...322

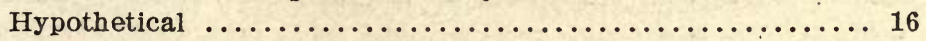

Whole number of species treated in this Catalogue.....338

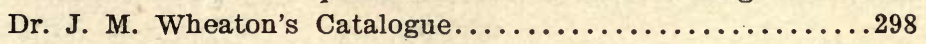




\section{BIBLIOGRAPHY OF OHIO ORNITHOLOGY}

This bibliography includes that given by Dr. Wheaton, in a somewhat abbreviated form, and such other books, catalogues and periodicals as have appeared since 1882, which contain references to Ohio birds. It makes no pretensions to being a complete bibliography, but serves to show from what sources my information has been derived. Some references are of a decidedly general nature, others specific.

1808-14.

Wilson, Alexander. American Ornithology. Vols. I-IX.

1825-33.

Bonaparte, C. L. American Ornithology. Vols I-IV.

1831-39.

Audubon, J. J. Ornithological Biography. Vols. I-IV.

1832-34.

Nuttall, T. A Manual of the Ornithology of the United States and of Canada. Vols. I-II.

1838.

Atwater, Caleb. A History of the State of Ohio, Natural and Civil.

1838-74.

Kirtland, Jared P., M.D. Various writings: First and Second Annual Reports on the Geological Survey of the State of Ohio, 1838; articles in the Am. Jour. Sci. and Arts, 1841, 1852; articles in Family Visitor, 1850-52; Ohio Farmer, 1860; Proc. Cleveland Acad. Nat. Sci., 1874.

\section{0-44.}

Audubon, J. J. The Birds of America, from drawings made in the United States and their Territories. Seven volumes.

1845.

Storer, D. H. Proc. Boston Soc. Nat. Hist. II.

1852.

Balrd, S. F. Description of a new species of Sylvicola (Dendroica kirtland1). Ann. Lyc. N. Y., V, 217.

1852-3.

Read, M. C. (Editor.) Family Visitor. Catalogue of Birds of Ohio. 
1854.

Zuchold. Journal für Ornithologie. (Copy of description of D. kirtlandi.)

1855.

Cassin, J. Illustrations, etc. (of D. kirtlandi.)

1858.

Baird, S. F. Birds, Pacific R. R. Report.

1859.

Brewer, T. M.' North Am. Oology. Smithsonian Contributions.

Kirkpatrick, John. Articles in Ohio Farmer and Ohio Agri. Report.

\section{1.}

Trembly, J. B. Articles in Field Notes.

Wheaton, J. M. Articles in Field Notes. Also Catalogue of Birds of Ohio (Ohio Agri. Report for 1860), and Reprint of same.

Collins, W. O. Fifteenth Annual Report Ohio State Board of Agri. for 1860.

Harris, S. D. (Editor.) Field Notes, I, Introduction of Skylark at Columbus.

$$
1864 .
$$

Hough, F. B. Executive Document No. 55, House of Representatives, 36th Congress, 1st Session. (Migration dates.)

Baird, S. F. Smithsonian Miscellaneous Collections.

1867.

Brewer, T. M. Article in the American Naturalist on habits of birds.

\section{8.}

March, P. G. Kingfisher's Nest again. Am. Naturalist, II. - Garlick, T. Migrations of Birds. Am. Naturalist, II.

\section{9.}

Ingersoll, Ernest. Variation of Bluebird's Eggs. Am. Naturalist, III.

\section{2.}

Coues, Elliott. Key to North American Birds.

Cope, E. D. Zoological Sketch of Ohio. Topographical Atlas.

Maynard, C. J. A Catalogue of the Birds of Coos county, N. H., and Oxford county, Me. Proc. Boston Soc. Nat. Hist.

1874.

Ridgway, Robert. Birds of Illinois. Ann. Lyc. Nat. Hist., N. Y., X.

Baird, Brewer, and Ridgway. A History of North American Birds. Vols. I-III. 
Coues, Elliott. U. S. Geol. Surv. of the Territories. Birds of the Northwest.

Wheaton, J. M. Notes in Birds of the Northwest. 1875.

Wheaton, J. M. The Food of Birds as Related to Agriculture. O. Agri. Report for 1874 .

1876.

Jordon, D. S. Manual of the Vertebrates of the Northern U. S. Henshaw, H. W. On two Empidonaces, traillii and acadicus. Bull. Nut. Orn. Club, I.

1877-80.

Langdon, F. W., M. D. Articles in the Bull. Nutt. Orn. Club, and Journal Cin. Soc. Nat. Hist.

Dury, Charles. Same references.

Wheaton, J. M. Same references.

1877-8.

Merriam C. Hart. A Review of the Birds of Connecticut. Trans. Conn. Acad. 1877. Remarks on some of the Birds of Lewis county, Northern New York. Bull. Nutt. Orn. Club, III.

1878.

Ridgway, Robert. Eastward range of Chondestes grammacus. Bull. Nutt. Orn. Club, III.

Ballou, W. H. The Națural History of the Islands of Lake Erie. Field and Forest, III.

Coues, Elliott. U. S. Geol. Surv. of the Territories. Birds of Colorado Valley.

\section{8-9.}

Brewster, W. Descriptions of the First Plumage in various species of North American Birds. Bull. Nutt. Orn. Club, III-IV.

\section{8-82.}

Jones, G. E. and Shultze, E. J. Illustrations of the Nests and Eggs of the Birds of Ohio with text. Circleville, Ohio.

1879.

Brewer, T. M. The Eggs of the Redstart. Bull. Nutt. Orn. Club, IV.

Marshall, D. M. The Butcher Bird. Journal of Science, new series, II.

Purdie, H. A. Another Kirtland Warbler. Bull. Nutt. Orn. Club, IV.

1880.

Chubb, H. E. Spring Field Notes. Forest and Stream, XIV, 307.

Ingersoll, Seym. Articles in Forest and Stream. 
Ridgway, Robert. Note of Helminthophaga cincinnatiensis. Bull. Nutt. Orn. Club, V.

1882.

Wheaton, J. M. Report upon the Birds of Ohio. Geol. Surv. of Ohio, IV. First published separately in 1879.

1884.

Coues, Elliott. Key to North American Birds.

Langille, Rev. J. H. Our Birds in Their Haunts.

Chubb, H. E. Birds and Electric Lights. Forest and Stream, XXII, 26.

1887.

American Ornithologists, Union Check-List.

Ridgway, Robert. Manual of North American Birds.

1889.

Davie, Oliver. Nests and Eggs of North American Birds.

Ridgway, Robert. Birds of Illinois.

Barrows, Walter B. The English Sparrow.

Dwight, Jonathan Jr. The Horned Larks of North America.

1890.

Warren, B. H. Birds of Pennsylvania.

1891.

Keyser, Leander S. Bird-dom.

\section{2.}

Bendire, Maj. Charles E. Life Histories of North American Birds.

Wilcox, E. V. Ohio Agri. Ex. Sta., Bulletin 43, Food of Robins. 1893.

Fisher, A. K., M. D. Hawks and Owls as Related to the Farmer.

Fisher, A. K., M. D. The Hawks and Owls of the United States.

Cook, A. J. Birds of Michigan.

1895.

Chapman, Frank M. Handbook of the Birds of Eastern North America.

Barrows, W. B. and Schwarz, E. A. The Common Crow of the United States.

Beal, F. E. L. Preliminary Report on the Food of Woodpeckers.

1896.

Oberholser, H. C. Birds of Wayne county, Ohlo.

1897.

Butler, A. W. Birds of Indiana. 
1898.

Apgar, A. C. Birds of the United States.

1899.

Chapman, F. M. Bird-Life. 1900-1903.

Ridgway, Robert. Birds of North and Middle America.

The following list of periodicals has contained so many references to Ohio birds that it is not deemed necessary to assign the particular references to the several years and authors. Some of these periodicals have long since been unobtainable, some have ceased to be, some are scaicely out of their swaddling clothes.

American Ornithology. Published at Worcester, Mass.

Annual Reports, Ohio State Academy Science, Columbus, Ohio.

Auk, The. New York City.

Bird-Lore. Harrisville, Pa.

Birds and Nature. Chicago, Ill.

Bulletin Michigan Ornithological Club. Detroit, Mich.

Iowa Ornithologist. Long since discontinued.

Journal Cincinnati Society of Natural History. Cincinnati, Ohio.

Journal Columbus Horticultural Society.

Museum, The. Discontinued.

Forest and Stream, New York City.

Observer, The. Discontinued.

Oologist, The. Albion, N. Y.

Ornithologist and Oologist, The. Discontinued.

Ornithologists' and Oologists' Semi-Annual. Continued as Wilson Bulletin.

Osprey, The. Washington, D. C.

Popular Science News.

Science. Lancaster, Pa.

Swill-Cross. Discontinued.

Taxidermist, The. Discontinued.

Wilson Bulletin, The. Oberlin, Ohio.

Wilson Quarterly. Continued as Wilson Bulletin.

Young Oologist. Continued as Oologist. 


\section{INDEX.}

Acanthis linaria, 138.

Accipiter atricapillus, 91. cooperi, 90. velox, 89 .

Actitis macularia, 77.

Actodromas bairdii, 70 . fuscicollis, 69 .

maculata, 69 . minutilla, 70 .

Eglalitis meloda, 81 . circumcincta, 82. semipalmata, 81 . vocifera, 80 .

Estrelata hasitata, 214.

Agelaius phoniceus, 131. fortis, 132.

Aix sponsa, 41.

Alauda arvensis, 223.

Ammodramus henslowii, 144. nelsoni, 145.

sandwichensis savanna, 143. savannarum passerinus, 144.

Ampelis cedrorum, 165. garrulus, 164.

Anas boschas, 37 . obscura, 37. rubripes, 38 .

Anser albifrons gambeli, 49 .

Anthus pensilvanicus, 194.

Antrostomus vociferus, 117.

Aquila chrysaetos, 95.

Archibuteo lagopus sancti-johannis, 94.

Ardea candidissima, 55 . cærulea, 55 .

egretta, 54.

herodias, 54.

virescens, 56 .

Ardetta exilis, 53. neoxena, 226.

Arenaria interpres, 82.

Arquatella maritima, 69.

Asio accipitrinus, 103. wilsonianus, 102.

Astragalinus tristis, 139.

Avocet, American, 64 .

Aythya affinis, 43 .

americana, 41.

collaris, 43. marila, 42.

vallisneria, 42 .

Bæolophus bicolor, 204.

Baldpate, 38.

Bartramia longicauda, 76 .

Bittern, American, 52.

Cory Least, 226.

Least, 53.

Blackbird, Red-winged, 7, 132.

Rusty, 134.

Thick-billed, 132.

Yellow-headed, 218.

Bluebird, 15, 211.

Bob-white, 83, 84 .

Bobolink, 14, 129.

Bonasa umbellus, 84 .

Botaurus lentiginosus, 52.

Brant, 226.

Branta bernicla, 226.

canadensis, 49. hutchinsii, 50.

Bubo virginianus, 107.

Buffihead, 45.

Bunting, Indigo, 156.

Painted, 227.

Buteo borealis, 92 . calurus, 217.

lineatus, 93.

platypterus, 93.

Butorides virescens, 56.

Calcarius lapponicus, 141.

Calidris arenaria, 72.

Campephilus principalis, 226 .

Canvas-back, 42.

Cardinal, 14, 15, 154.

Cardinalis cardinalis, 154.

Carduelis carduelis, 223.

Carpodacus purpureus, 137.

Catbird, 196.

Catharistes urubu, 87.

Cathartes aura, 87.

Centurus carolinus, 115.

Ceophlœus pileatus abieticola,

114.

Certhia familiaris americana,

201.

Ceryle alcyon, 111.

Chætura pelagica, 118.

Charadrius dominicus, 79 . 
Charitonetta albeola, 45.

Chat, Yellow-breasted, 191.

Chaulelasmus streperus, 38.

Chen cærulescens, 49.

hyperborea, 48 . nivalis, 48 .

Chewink, 154.

Chickadee, 204.

Carolina, 17, 205.

Chondestes grammacus, 145.

Chordeiles virginianus, 117.

Circus hudsonius, 88.

Cistothorus palustris, 201. stellaris, 200.

Clangula clangula americana, 44 . islandica, 44.

Clivicola riparia, 162.

Coccothraustes vespertinus, 136.

Coccyzus americanus, 109. erythrophthalmus, 110.

Colaptes auratus luteus, 116.

Colinus virginianus, 83.

Colymbus auritus, 22. holbœllii, 23.

Compsothlypis americana usneæ, 176. ramalinæ, 177

Contopus borealis, 121. virens, 122.

Conurus carolinensis, 222.

Coot, American, 62.

Cormorant, Double-crested, 34 . Florida, 225.

Corvus americanus, 128. corax principalis, 127.

Coturniculus savannarum pas-

Cowbird, 130. serinus, 144.

Crane, Little Brown, 216.

Sandhill, 58.

Whooping, 57.

Creeper, Brown, 201.

Crossbill, American, 137.

White-winged, 138.

Crow, American, 128. Carrion, 127.

Crymophilus fulicarius, 226

Cuckoo, Black-billed, 110. Yellow-billed, 109.

Curlew, Eskimo, 78 . Hudsonian, 78 . Long-billed, 77.

Cyanocitta cristata, 126.

Cyanospiza ciris, 227. cyanea, 156.

Dabchick, 24.

Dafila acuta, 40.
Dendroica æstiva, 178.

blackburniæ, 183.

cærulescens, 178.

castanea, 182.

coronata, 179.

discolor, 187.

dominica albilora, 184.

kirtlandi, 185.

maculosa, 180 .

palmarum, 186. hypochrysea, 219.

pensylvanica, 181 .

rara, 180.

striata, 182.

tigrina, 177.

vigorsii, 186.

virens, 184.

Dickcissel, 15, 17, 156.

Dolichońyx, oryzlvorus, 129.

Dowitcher, 67.

Long-billed, 17, 67.

Dove, Mourning, 86.

Dryobates borealis, 217.

pubescens medianus 112. villosus, 111.

Duck, Black, 37.

American Eider, 46.

Harlequin, 225.

King Eider, 46.

Lesser Scaup, 43.

Red-legged Black, 38 .

Ring-necked, 43.

Ruddy, 47.

Scaup, 42.

Wood, 41.

Eagle, Bald, 96.

Golden, 6, 95.

Ectopistes migratorius, 85 .

Egret, American, 54.

Egretta candidissima, 55.

Eider, American, 17, 46.

King, 46.

Elanoides forficatus, 88 .

Empidonax flaviventris, 122.

minimus, 124.

traillii, 123.

alnorum, 227.

virescens, 123.

Ereunetes pusillus 71 .

Erismatura jamaicensis, 47.

Falco columbarius, 98.

peregrinus anatum, 97.

sparverius, 99.

Finch, Purple, 137.

Flicker, Northern, 116.

Florida cærulea, 55.

Flycatcher, Alder, 227. 
Crested, 120.

Green-crested, 123.

Least, 124.

Olive-sided Flycatcher, 121.

Scissor-tailed, 218.

Traill, 123.

Yellow-bellied, 122.

Fregata aquila, 214.

Fulica americana, 62 .

Gadwall, 38.

Galeoscoptes carolinensis, 196.

Gallinago delicata, 66 .

Gallinula galeata, 62 .

Gallinule, Florida, 62.

Purple, 61.

Gavia arctica, 25.

imber, 25.

lumme, 26.

Gelochelidon nilotica, 31 .

Geothlypis agilis, 190.

formosa, 189 .

philadelphia, 190.

trichas brachydactyla, 191 .

Gnatcatcher, Blue-gray, 6, 206.

Godwit, Hudsonian, 73. Marbled, 72.

Golden-eye, American, 44.

Barrows, 17, 44.

Goldfinch, European, 223.

American, 139.

Goose, American White-fronted,

Blue, 49.

Canada, 49.

Greater Snow, 48.

Hutchins, 50.

Lesser Snow, 48.

Goshawk, American, 91.

Grackle, Bronzed, 6, 131, 135.

Grebe, Holbœll, 23.

Horned, 23, 24.

Pied-billed, 24.

Grosbeak, Blue, 15, 227.

Canadian Pine, 136.

Evening, 136.

Rose-breasted, 155.

Grouse, Ruffed, 84.

Grus americana, 57. canadensis, 216.

mexicana, 58.

Guiraca cærulea, 227.

Gull, Bonaparte, 30 .

Herring, 29.

Iceland, 28.

Glaucus, 225.

Great Black-backed, 28.

Ring-billed, 29.
Sabine, 30.

Haliæetus leucocephalus, 96.

Harelda hyemalis, 45.

Hawk, American Rough-legged,

American Sparrow, 99.

94.

Broad-winged, 93.

Cooper, 90.

Duck, 97.

Marsh, 88.

Pigeon, 98.

Red-shouldered, 93.

Red-tailed, 7, 92.

Sharp-shinned, 89.

Western Red-tailed, 217.

Helmitheros vermivorus, 173.

Helminthopila celata, 175 .

cincinnatiensis, 228.

chrysoptera, 174.

leucobronchialis,, 228.

peregrina, 176.

pinus, 174.

rubricapilla, 175 .

Helodromas solitarius. 74 .

Hen, Prairie, 221.

Herodias egretta, 54.

Heron, Black-crowned Night, 56.

Great Blue, 54.

Green, 56.

Little Blue, 17, 55.

Snowy, 55.

Hesperiphona vespertina, 136.

Himantopus mexicanus, 65 .

Hirundo erythrogaster, 161.

Histrionicus histrionicus, 225.

Hummingbird, Ruby-throated,

119.

Hydrochelidon nigra surinam-

Hylocichla aliciæ, 209. ensis, 33.

fuscescens, 208.

guttata pallasii, 210 .

mustelina, 207.

swainsoni, 209.

Ibis, Glossy, 216.

Wood, 51.

Icteria virens, 191.

Icterus galbula, 133 .

spurius, 133.

Ionornis martinica, 61.

Iridoprocne bicolor, 162 .

Jæger, Long-tailed, 224.

Parasitic, 17, 27.

Pomarine, 26.

Jay, Blue, 126.

Junco hyemalis, 150.

Junco, Slate-colored, 150. 
Killdeer, 18, 80.

Kingbird, 120.

Kingfisher, Belted, 111.

Kinglet, Golden-crowned, 205. Ruby-crowned, 206.

Kite, Swallow-tailed, 88.

Kittiwake, 224.

Knot, 68.

Lanius borealis, 166 .

ludovicianus, 167. excubitorides, 167. migrans, 167.

Lark, Horned, 124. Hoyt Horned, 126.

Prairie Horned, 17, 125.

Larus argentatus, 29. delawarensis, 29. glaucus, 225 .

leucopterus, 28. marinus, 28. philadelphia, 30 . sabinii, 30 .

Limosa fedoa, 72 . hæmastica, 73 .

Longspur, Lapland, 141.

Loon, 25.

Black-throated, 25. Red-throated, 26.

Lophodytes cucullatus, 36 .

Loxia curvirostra minor, 137. lucoptera, 138.

Macrorhamphus griseus, 67. scolopaceus, 67.

Mallard, 37.

Man-o'-War Bird, 214.

Mareca americana 38. penelope, 215.

Martin, Purple, 159.

Meadowlark, 6, 18, 132.

Megascops asio, 106.

Melanerpes carolinus, 115. erythrocephalus, 114 .

Meleagris gallopavo sylvestris,

85.

Melospiza cinerea melodia, 151 georgiana, 152. lincolni, 152.

Merganser americanus, 35 . serrator, 35 .

Merganser, American, 35. Hooded, 36.

Red-breasted, 35

Merula migratoria, 210.

Micropalama himantopus, 68 .

Mimus polyglottos, 195.

Mniotilta varia, 172.

Mockingbird, 195.
Molothrus ater, 130 .

Murre, Brünnich, 213.

Muscivora forficata, 218.

Myiarchus crinitus, 120.

Nettion carolinensis, 39.

Nighthawk, 117.

Nonpareil, 15.

Numenius borealis, 78 . hudsonicus, 78 . longirostris, 77 .

Nuthatch, Brown-headed, 219. Red-breasted, 203.

White-breasted, 202.

Nyctala acadica, 105 .

Nyctea nyctea, 108.

Nycticorax nycticorax nævius,

Oidemia americana, 46. 56. deglandi, 47. perspicillata, 226 .

Olbiorchilus hiemalis, 200 .

Old-squaw, 45.

Olor buccinator, 51. columbianus, 51.

Oriole, Baltimore, 133. Orchard, 133.

Osprey, American, 100.

Otocoris alpestris, 124. hoyti, 126. praticola, 125 .

Oven-bird, 6, 187.

Owl, American Hawk, 109. American Long-eared, 102.

Barn, 101.

Barred, 104.

Great Gray, 7, 105.

Great Horned, 107.

Saw-whet, 105.

Screech, 106.

Short-eared, 103.

Snowy, 108.

Oxyechus vociferus, 80 .

Pandion haliaetus carolinensis,

Paroquet, Carolina, 222.

100.

Parus atricapillus, 204.

bicolor, 204.

carolinensis, 205.

Passer domesticus, 220.

Passerculus sandwichensis savanna, 143 .

Passerella iliaca, 153.

Passerina nivalis, 140.

Pavoncella pugnax, 217.

Pelecanus erythrorhynchos, 34 .

Pelican, American White, 34 .

Pelidna alpina pacifica, 71 . 
Petrel, Black-capped, 214.

Petrochelidon lunifrons, 160.

Peucæa æstivalis bachmanii,

Pewee, Wood, 6, 122.

Phalacrocorax dilophus, 34 . floridanus, 225.

Phalarope, Northern, 63.

Red, 226.

Wilson, 64 .

Phalaropus lobatus, 63.

Phasianus torquatus, 220.

Pheasant, Ring-necked, 220.

Philohela minor, 65 .

Phœbe, 121.

Picoides arcticus, 113.

Pigeon, Passenger, 85.

Pinicola enucleator leucura, 136.

Pintail, 40.

Pipilo erythrophthalmus, 154.

Pipit, American, 194.

Piranga erythromelas, 157. rubra, 158.

Plegadis autumnalis, 216.

Plover, American Golden, 79. Belted Piping, 82.

Black-bellied, 79 .

Piping, 81.

Semipalmated, 81.

Podilymbus podiceps 24 .

Polioptila cærulea, 206.

Poœcetes gramineus, 142.

Porzana carolina, 59 . jamaicensis, 61 . noveboracensis, 60 .

Progne subis, 159.

Protonotaria citrea, 172.

Querquedula cyanoptera, 215. discors, 39.

Quiscalus quiscula æneus, 135.

Rail, Black, 17, 61.

King, 59.

Virginia, 59.

Yellow, 60.

Rallus elegans, 59. virginianus, 59 .

Raven, Northern, 127.

Recurvirostra americana, 64 .

Red-head, 41.

Redpoll, 138.

Red-tail, western, 217.

Red-wing, 132.

Thick-billed, 132.

Regulus calendula, 206. satrapa, 205.

Riparia riparia, 162 .

Rissa tridactyla, 224.
Robin, American, 6, 7, 15, 210.

Ruff, 217.

Sanderling, 72.

Sandpiper, Baird, 70.

Bartramian, 76.

Buff-breasted, 76 .

Least, 70.

Pectoral, 69.

Purple, 69.

Red-backed, 71.

Semipalmated, 71 .

Solitary, 74.

Spotted, 77.

Stilt, 68.

White-rumped, 69.

Sapsucker, Yellow-bellied, 113.

Sayornis phœbe, 121.

Scolecophagus carolinus, 134.

Scoter, American, 46.

Surf, 226.

White-winged, 47.

Scotiaptex nebulosa, 105 .

Setophaga ruticilla, 194.

Seiurus aurocapillus, 187.

motacilla, 189.

noveboracensis, 188. notabilis, 227.

Shoveller, 40.

Shrike, Loggerhead, 167.

Migrant, 167.

Northern, 166.

White-rumped, 167.

Sialia sialis, 212.

Siskin, Pine, 15, 140.

Sitta canadensis, 203. carolinensis, 202. pusilla, 219.

Skylark, 223.

Snipe, Wilson, 15, 66.

Snowflake, 140.

Somateria dresseri, 46. spectabilis, 46 .

Sora, 59.

Sparrow, Bachman, 17, 150.

Chipping, 148.

English, 6, 220.

Field, 149.

Fox, 153.

Grasshopper, 17, 144.

Harris, 219.

Henslow, 17, 144.

Lark, 15, 17, 145.

Lincoln, 152.

Nelson, 17, 145.

Savanna, 143.

Song, 151.

Swamp, 152. 
Tree, 148.

Vesper, 6, 142.

White-crowned, 146.

White-throated, 147.

Spatula clypeata, 40.

Sphyrapicus varius, 113.

Spinus pinus, 140.

Spiza americana, 156.

Spizella monticola 148.

pusilla, 149.

socialis, 148.

Squatarola squatarola, 79.

Steganopus tricolor, 64.

Stelgidopteryx serripennis, 163.

Sercorarius longicaudus, 224.

parasiticus, 27.

pomarinus, 26.

Sterna antillarum, 33.

caspia, 31 .

dougalli, 32.

fosteri, 31 .

hirundo, 32.

maxima, 225.

paradisæa, 225 .

Stilt, Black-necked, 65.

Strix pratincola, 101.

Sturnella magna, 132.

Surnia ulula caparoch, 109.

Swallow, Bank, 162.

Barn, 161.

Cliff, 160.

Rough-winged, 163.

Tree, 162.

Swan, Trumpeter, 51.

Whistling, 51.

Swift, Chimney, 118.

Symphemia semipalmata, 75 .

Syrnium varium, 104.

Tachycineta bicolor, 162 .

Tanager, Scarlet, 157.

Summer, 14, 15, 158.

Tantalus loculator, 51 .

Teal, Blue-winged, 39 .

Cinnamon, 215.

Green-winged, 39.

Telmatodytes palustris, 201.

Tern, Arctic, 225.

Black, 14, 33.

Caspian, 17, 31.

Common, 14, 32.

Forster, 31.

Gull-bilied, 31.

Least, 33.

Roseate, 32.

Royal, 225.

Thrasher, Brown, 197.

Thrush, Gray-cheeked, 209.
Hermit, 210.

Olive-backed, 209.

Wilson, 14, 208 .

Wood, 207.

Thryomanes bewickii, 198.

Thryothorus ludovicianus, 198.

Titmouse, Tufted, 204.

Totanus flavipes, 74 .

melanoleucus, 73 .

Towhee, 154.

Toxostoma rufum, 197.

Tringa alpina pacifica, 71 . bairdii, 70 .

canutus, 68.

fuscicollis, 69 .

maculata, 69 .

maritima, 69 .

minutilla, 70 .

Trochilus colubris, 119.

Troglodytes aedon, 199.

Tryngites subruficollis, 76 .

Turkey, Wild, 85.

Turnstone, 82.

Tympanuchus americanus, 221.

Tyrannus tyrannus, 120.

Uria lomvia, 213.

Vireo flavifrons, 170.

gilvus, 169.

noveboracensis, 171.

olivaceus, 168.

philadelphicus, 169.

solitarius, 170 .

Vireo, Blue-headed, 170.

Philadelphia, 169.

Red-eyed, 168.

Warbling, 169.

White-eyed, 14, 15, 17, 171.

Yellow-throated, 170.

Vulture, Black, 87.

Turkey, 15, 87.

Warbler, Bay-breasted, 182.

Black and White, 172.

Blackburnian, 183.

Black-poll, 182.

Black-throated Blue, 178.

Black-throated Green, 184

Blue-winged, 174.

Brewster, 228.

Canadian, 193.

Cape May, 177.

Cerulean, 180.

Chestnut-sided, 15, 181.

Cincinnati, 228.

Connecticut, 190.

Golden-winged, 14,15, 17,

Hooded, 14, 15, 17, 192.
174. 
Kentucky, 14, 15, 17, 189.

Kirtland, 185.

Magnolia, 15, 180.

Mourning, 190.

Myrtle, 179.

Nashville, 175.

Northern Parula, 176.

Orange-crowned, 175.

Palm, 186.

Pine, 186.

Prairie, 187.

Prothonotary, 15, 17, 172.

Sycamore, 184.

Tennessee, 176.

Western Parula, 177.

Wilson, 193.

Worm-eating, 14, 15, 17,

Yellow, 178.

Yellow Palm, 219.

Water-Thrush, 188.

Grinnell, 227.

Louisiana, 189.

Waxwing, Bohemian, 164.

Cedar, 165.

Whippoorwill, 117.

Widgeon, European, 215.

Willett, 75.

Wilsonia canadensis, 193. mitrata, 192.

pusilla, 193.

Woodcock, American, 65.

Woodpecker, Arctic Three-toed,

113

Downy, 112.

Hairy, 111.

Ivory-billed, 226.

Northern Pileated, 114.

Red-bellied, 115.

Red-cockaded, 217.

Red-headed, 114.

Wren, Bewick, 15, 17, 198.

Carolina, 14, 15, 17, 198.

House, 199.

Long-billed Marsh, 201.

Short-billed Marsh, 200.

Winter, 200.

Xanthocephalus xanthocepha-

Xema sabinii, 30 . lus, 218.

Yelow-legs, 74.

Greater, 73 .

Yellow-throat, Northern, 191.

Zamelodia ludoviciana, 155.

Zenaidura macroura, 86.

Zonotrichia albicollis, 147.

leucophrys, 146.

querula, 219. 






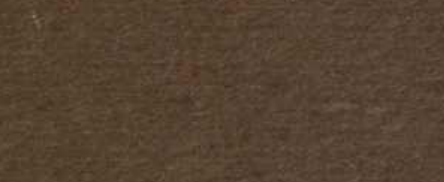


\title{
SPECIAL PAPERS
}

\author{
of $\mathrm{xu}$
}

\section{OHIO STATE ACADEMY OF SCIENCE}

No. 1. SANDUSKY FLORA.

By E. L. Moseley, A.M.

No. 2. THE ODONATA OF OHIO.

By David S. Kellicott, Ph.D.

No. 3. THE PREGLACIAL DRAINAGE OF OHIO. By W. G. Tight, M.S. J. A. BOWNOCKER, M.D. J. H. TODD, M.D.

GERARD FOWKE.

No. 4. THE FISHES OF OHIO.

By Raymond C. Osbern, M.Sc.

No. 5. THE TABANIDAE OF OHIO. By James S. Hine, A.M.

No. fi. THE BIRDS OF OHIO. By Lynas Jones, M.Sc.

Address, W. C. Mrlls, Librarian, Ohio State University, Columbus, Ohio. 






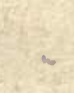

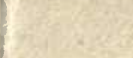
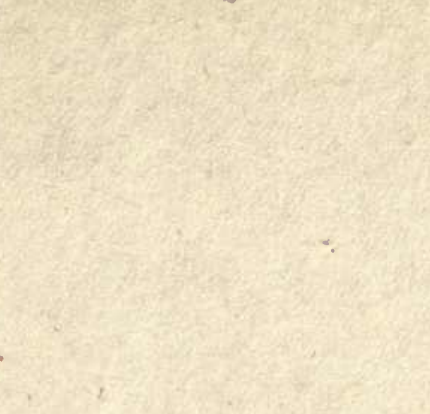
